MÁRCIA GATTI KOURI

DEFINIÇÃO DE REQUISITOS PARA UM SISTEMA DE

MONITORAMENTO DE VEÍCULOS NO TRANSPORTE RODOVIÁRIO DE CARGAS 
MÁRCIA GATTI KOURI

\title{
DEFINIÇÃO DE REQUISITOS PARA UM SISTEMA DE MONITORAMENTO DE VEÍCULOS NO TRANSPORTE RODOVIÁRIO DE CARGAS
}

\author{
Dissertação apresentada à Escola Politécnica da \\ Universidade de São Paulo para a obtenção do título de \\ Mestre em Engenharia Elétrica
}

São Paulo 
MÁRCIA GATTI KOURI

\title{
DEFINIÇÃO DE REQUISITOS PARA UM SISTEMA DE MONITORAMENTO DE VEÍCULOS NO TRANSPORTE RODOVIÁRIO DE CARGAS
}

\author{
Dissertação apresentada à Escola Politécnica da \\ Universidade de São Paulo para a obtenção do título de \\ Mestre em Engenharia Elétrica \\ Área de Concentração: \\ Sistemas Digitais
}

Orientador: Prof. Dr. Edison Spina

São Paulo 


\section{DEDICATÓRIA}

Ao meu querido esposo Flávio e as minhas adoradas filhas Gabriela e Carolina. 


\section{AGRADECIMENTOS}

Ao Prof. Dr. Edison Spina pela orientação e estímulo durante todo o trabalho.

Aos amigos Eduardo e Gilson pelo apoio e colaboração, tanto neste trabalho quanto no desenvolvimento da minha carreira profissional.

Ao meu esposo Flávio, cujo constante incentivo e valiosa colaboração foram essenciais para a conclusão deste trabalho.

As minhas filhas Gabriela e Carolina pela compreensão e paciência durante os momentos de ausência por conta desta dissertação. 


\section{RESUMO}

Esta dissertação apresenta o levantamento e definição dos requisitos necessários para um sistema de monitoramento de veículos no transporte rodoviário de cargas, cujo custo de implantação seja acessível a grande parte das empresas. Para isso são aplicados alguns métodos da Engenharia de Requisitos, tais como: Vord, Preview e Volere. O conjunto de requisitos obtido através deste levantamento é então utilizado como fonte para a especificação de requisitos do sistema proposto.

Palavras-chave: Levantamento de requisitos. Transporte rodoviário de cargas. 


\begin{abstract}
This dissertation shows the survey and definition of the necessary requirements regarding a monitoring system for vehicles that transport goods via roads, whose low cost implementation is accessible for most of the companies. For this purpose, some methods of the Engineering of Requirements are applied, such as: Vord, Preview and Volere. The set of requirements gotten via this survey is the source for the specification of requirements of the proposed system.
\end{abstract}

Keywords: Survey of requirements . Transport of goods via roads. 


\section{LISTA DE ILUSTRAÇÕES}

Figura 1 - Tipos de carga mais visadas para roubo ...........................................24

Figura 2 - Constelação Navstar .................................................................. 28

Figura 3 - Modelo espiral para o processo de Engenharia de Requisitos. ...............43

Figura 4 - Elementos de um caso de uso .................................................. 57

Figura 5 - Estrutura de classes dos pontos de vista.........................................66

Figura 6 - Estrutura da subdivisão da classe Desenvolvedor ...............................67

Figura 7 - Estrutura da subdivisão da classe Cliente .......................................67

Figura 8 - Estrutura da subdivisão da classe Usuário Final.....................................68

Figura 9 - Diagrama de contexto - monitoramento por cartão ...............................75

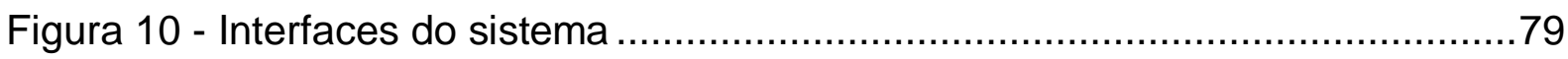

Figura 11 - Formulário de registro de requisitos do sistema................................84

Figura 12 - Interfaces do sistema (especificação de requisitos) ...........................133

Figura 13 - Cartão padrão de requisitos adaptado do método Volere....................163 


\section{LISTA DE TABELAS}

Tabela 1 - Divisão dos modais de transporte no Brasil e nos EUA .........................20

Tabela 2 - Quantidade de veículos por tipo de Transportador ...............................21

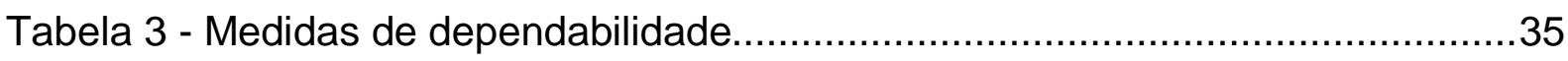

Tabela 4 - Entradas e saídas do processo de Engenharia de Requisitos ................42

Tabela 5 - Casos de uso do negócio .............................................................. 76

Tabela 6 - Casos de uso do sistema ....................................................... 80

Tabela 7 - Identificação dos pontos de vista da classe Desenvolvedor ..................140

Tabela 8 - Identificação dos pontos de vista da classe Cliente ..............................141

Tabela 9 - Identificação dos pontos de vista da classe Usuário Final ....................141 


\section{LISTA DE QUADROS}

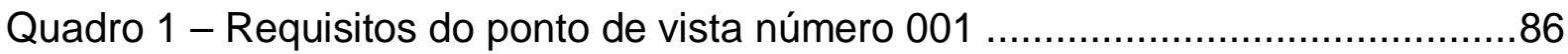

Quadro 2 - Requisitos do ponto de vista número 002 .....................................87

Quadro 3 - Requisitos do ponto de vista número 003 .......................................89

Quadro 4 - Requisitos do ponto de vista número 004 .......................................91

Quadro 5 - Requisitos do ponto de vista número 005 .......................................92

Quadro 6 - Requisitos do ponto de vista número 006 .....................................94

Quadro 7 - Requisitos do ponto de vista número 007 ....................................95

Quadro 8 - Requisitos do ponto de vista número 008 .......................................96

Quadro 9 - Requisitos do ponto de vista número 009 ......................................97

Quadro 10 - Requisitos do ponto de vista número 010....................................99

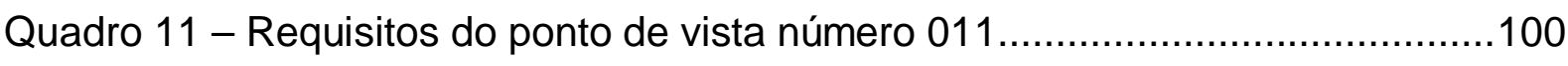

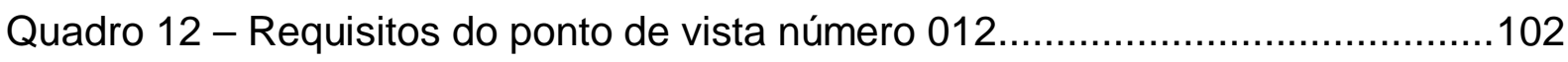

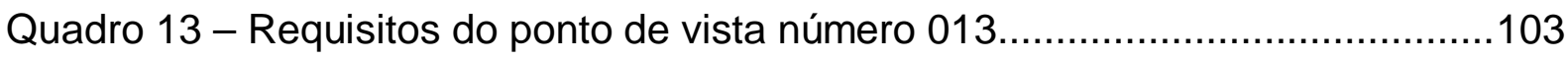

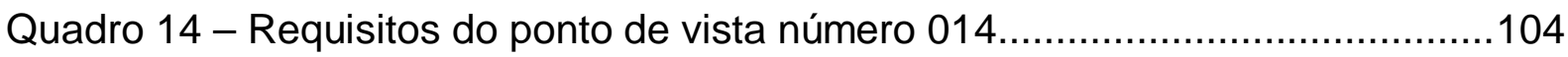

Quadro 15 - Requisitos de desenvolvimento ............................................... 108

Quadro 16 - Requisitos funcionais........................................................ 112

Quadro 17 - Requisitos de apresentação, usabilidade e fatores humanos.............115

Quadro 18 - Requisitos de desempenho ................................................... 116

Quadro 19 - Requisitos operacionais e de ambiente ....................................118

Quadro 20 - Requisitos de manutenção e suporte ..........................................119

Quadro 21 - Requisitos de segurança .......................................................120

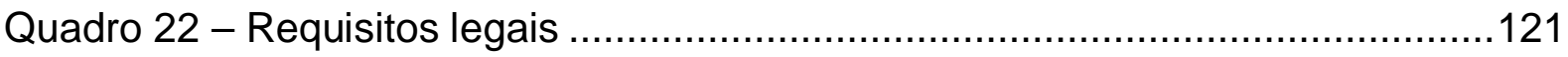




\section{LISTA DE ABREVIATURAS E SIGLAS}

ABNT

Anatel

ANTT

AVA

BVA

CNT

ER

ERB

Espiti

FETCESP

GPRS

GPS

GSM

IEEE

ISO

JAD

Navstar

NPV

PD

PIB

RF

TKm

TKU
Associação Brasileira de Normas Técnicas

Agência Nacional de Telecomunicações

Agência Nacional de Transportes Terrestres

Alto Valor Agregado

Baixo Valor Agregado

Confederação Nacional do Transporte

Engenharia de Requisitos

Estação Rádio Base

European Software Process Improvement Training Initiative

Federação das Empresas de Transportes de Cargas do

Estado de São Paulo

General Packet Radio Service

Global Positioning System

Global System for Mobile Communications

Institute of Electrical and Eletronics Engineers

International Standards Organization

Joint Application Design

Navigation System for Timing and Ranging

Número do Ponto de Vista

Participatory Design

Produto Interno Bruto

Radiofreqüência

Toneladas por Quilômetro

Toneladas por Quilômetro Útil 
TRC

Transportes Rodoviário de Cargas

UML

Unified Modeling Language 


\section{SUMÁRIO}

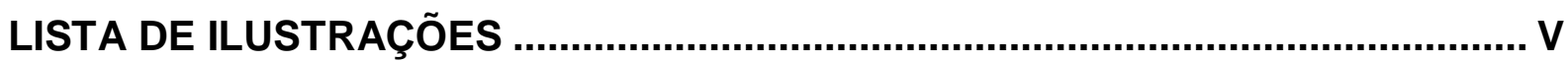

LISTA DE TABELAS ..................................................................................... VI

LISTA DE QUADROS.................................................................................... VII

LISTA DE ABREVIATURAS E SIGLAS .......................................................... VIII

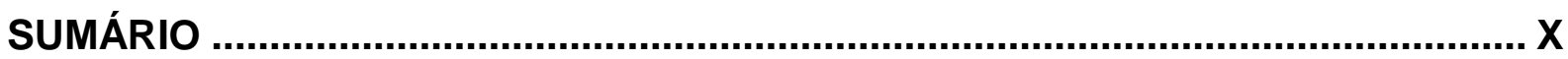

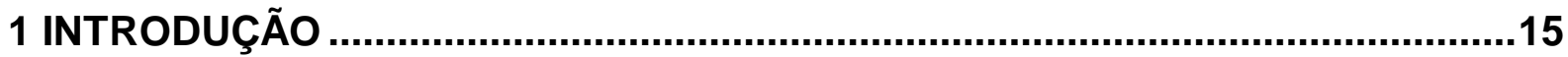

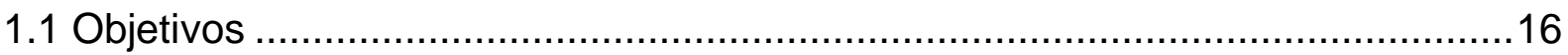

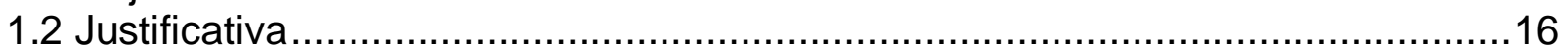

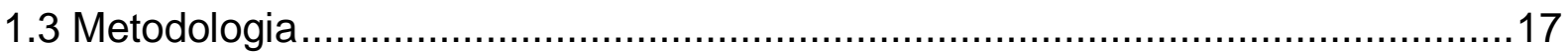

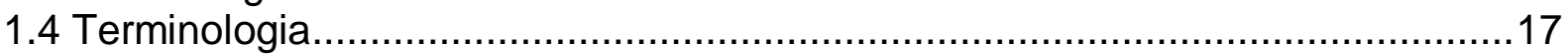

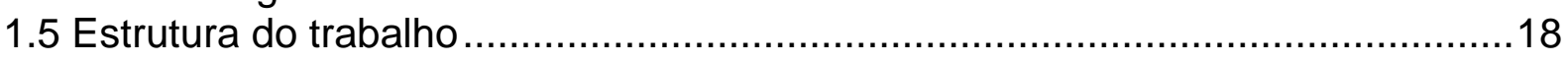

2 TRANSPORTE DE CARGAS NO BRASIL.......................................................19

2.1 Transporte Rodoviário de Cargas no Brasil....................................................21

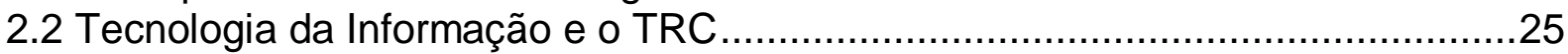

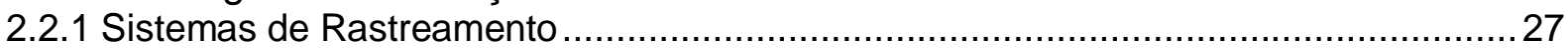

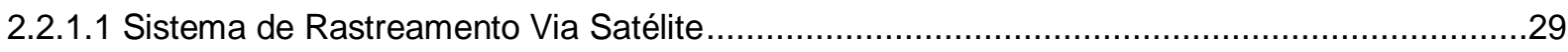

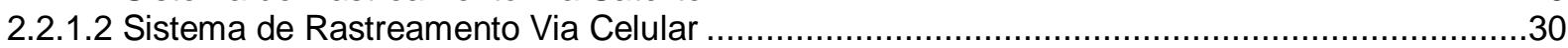

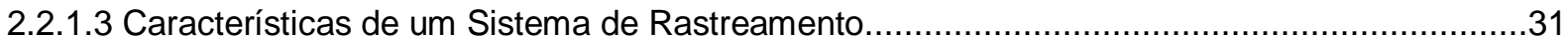

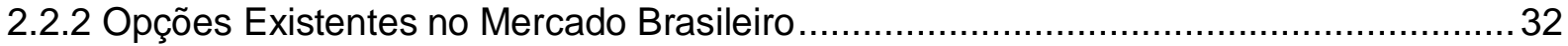

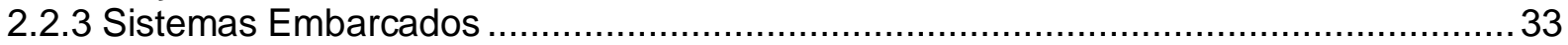

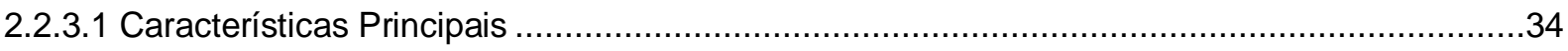

3 ENGENHARIA DE REQUISITOS ............................................................38

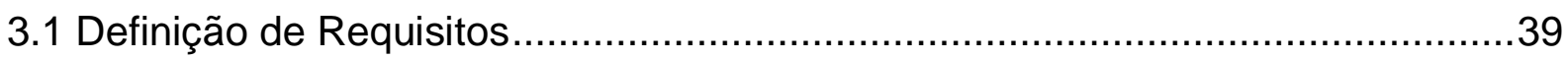

3.2 O Processo da Engenharia de Requisitos .......................................................

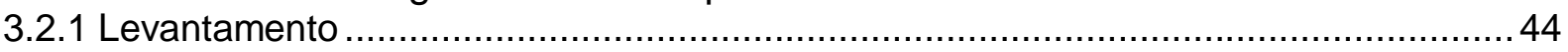

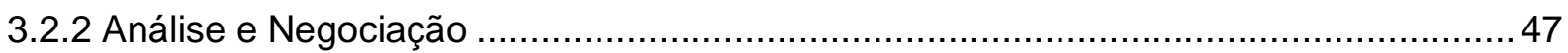

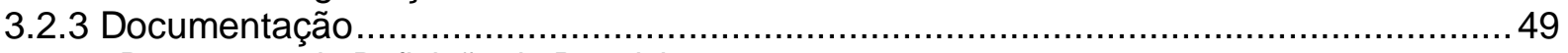

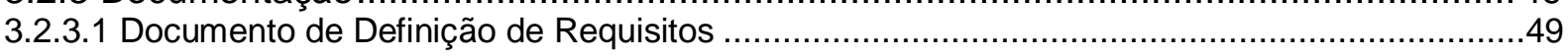

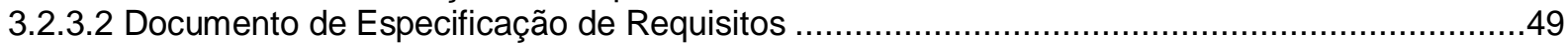

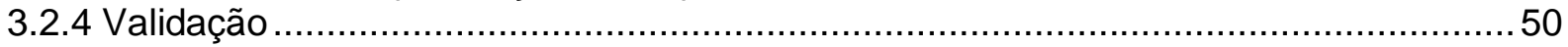

3.3 Técnicas e Métodos da Engenharia de Requisitos ......................................52

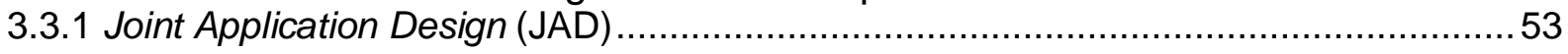

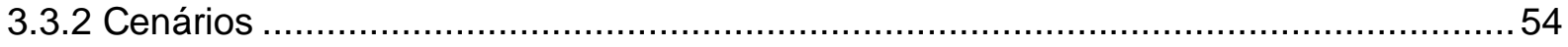

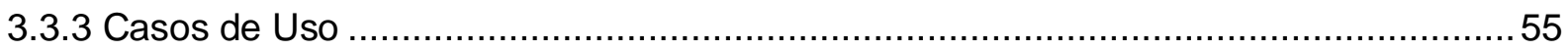

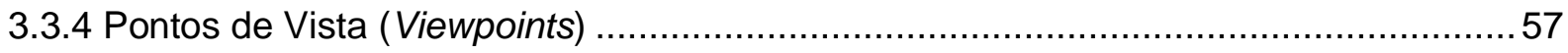

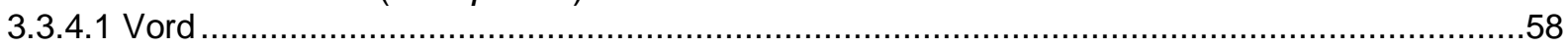

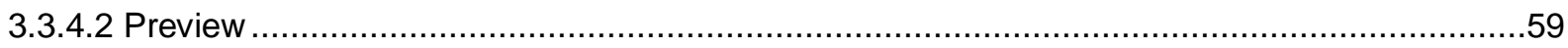

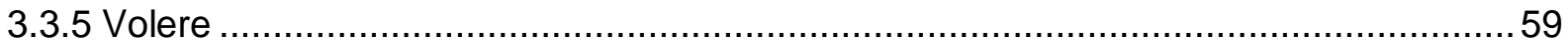

4 LEVANTAMENTO DE REQUISITOS PARA O SISTEMA PROPOSTO................60

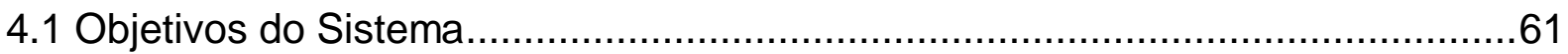

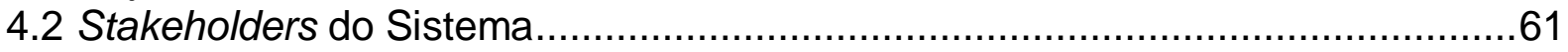

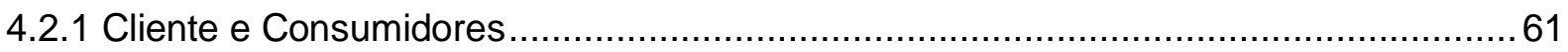

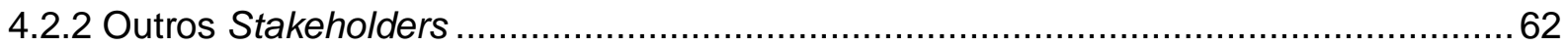




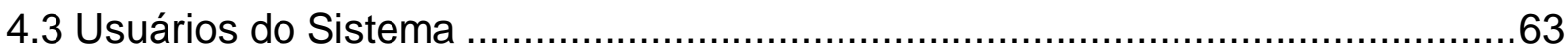

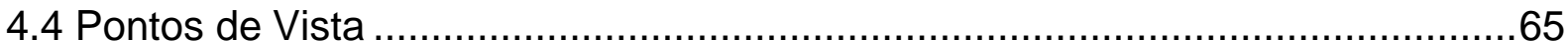

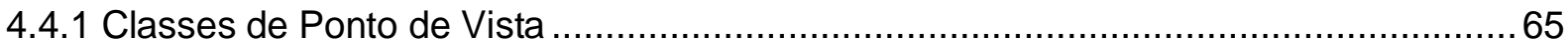

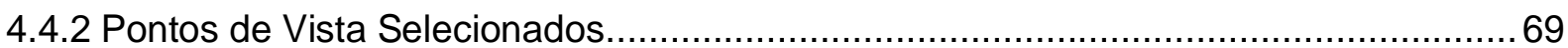

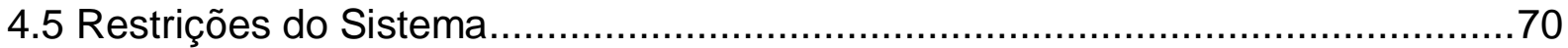

4.6 Nomenclaturas e Definições......................................................................73

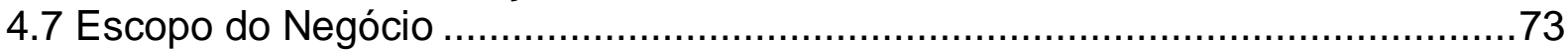

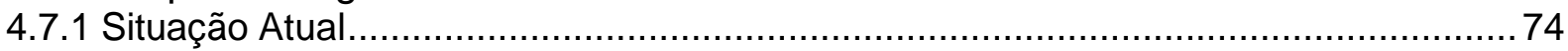

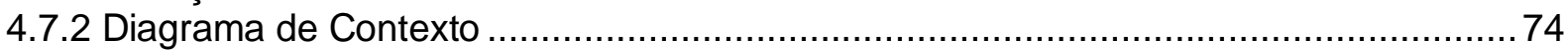

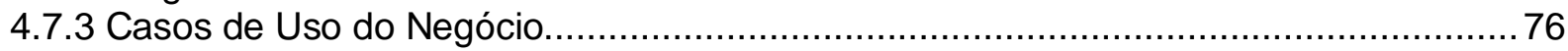

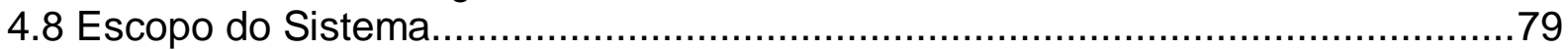

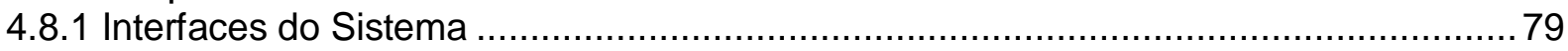

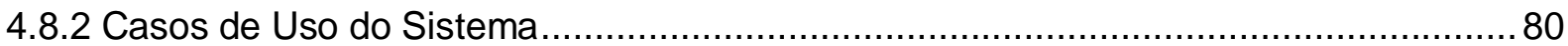

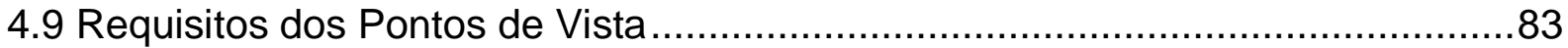

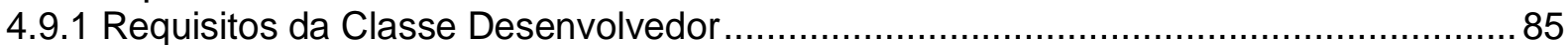

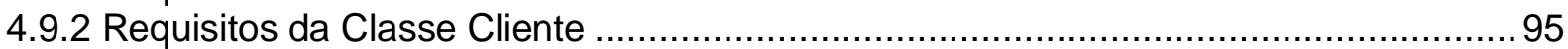

4.9.3 Requisitos da Classe Usuário Final................................................................ 100

4.10 Análise e Negociação dos Requisitos .......................................................105

5 DEFINIÇÃO DOS REQUISITOS PARA O SISTEMA PROPOSTO ......................106

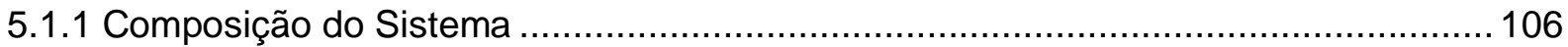

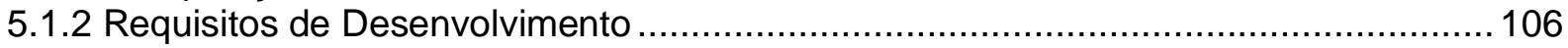

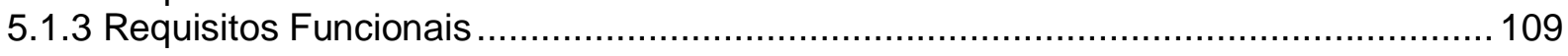

5.1.4 Requisitos de Apresentação, Usabilidade e Fatores Humanos................................113

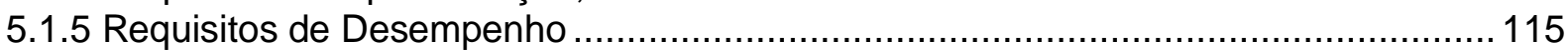

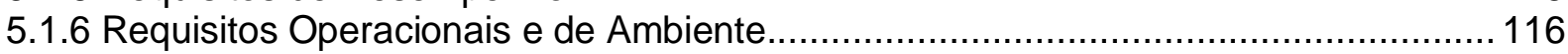

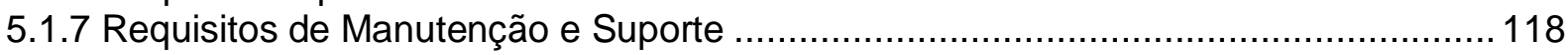

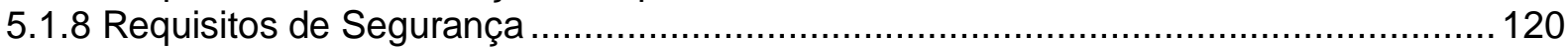

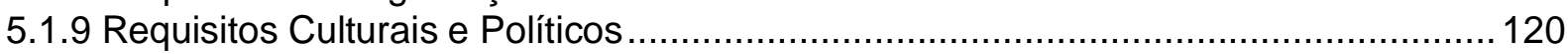

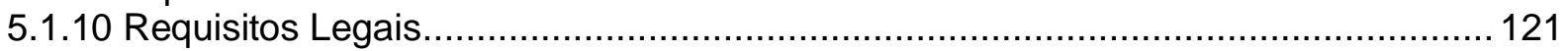

6 VALIDAÇÃO E ESPECIFICAÇÃO DOS REQUISTOS........................................122

7 CONSIDERAÇÕES FINAIS ......................................................................123

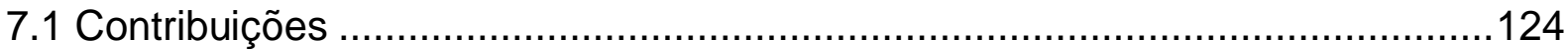

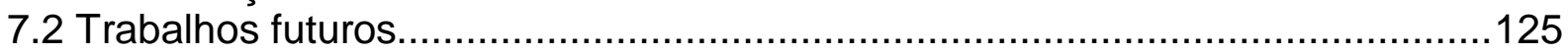

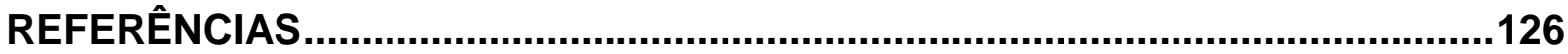

APÊNDICE A - ESPECIFICAÇÃO DE REQUISITOS PARA O SISTEMA DE TRANSPONDERS

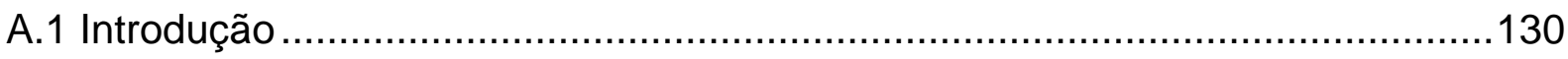

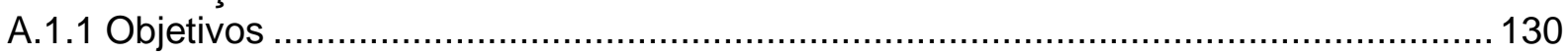

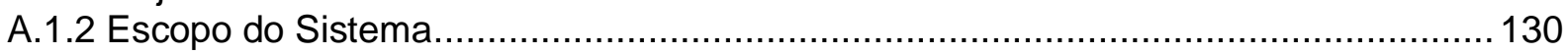

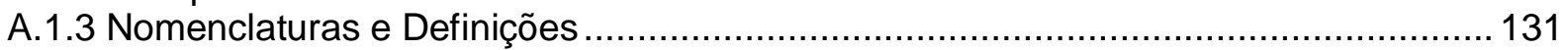

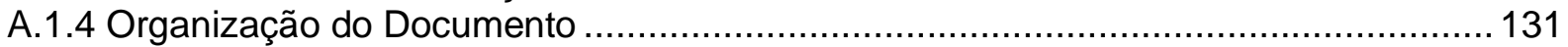

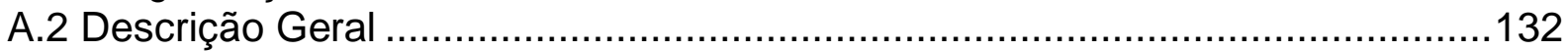

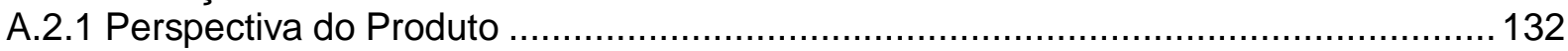

A.2.1.1 Interfaces .......................................................................................................... 133

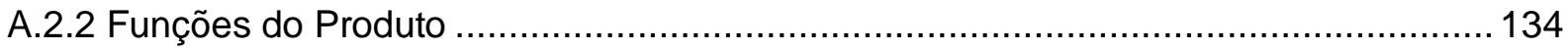

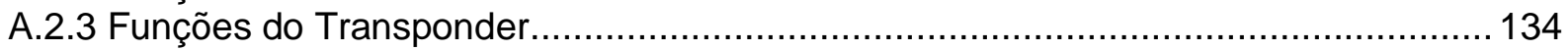

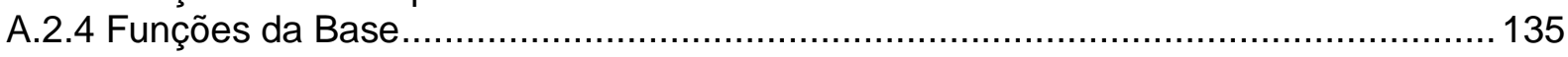

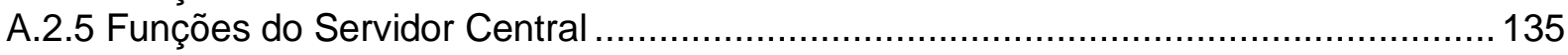

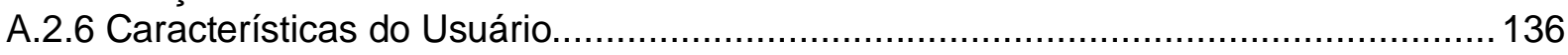

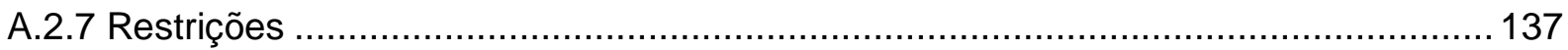




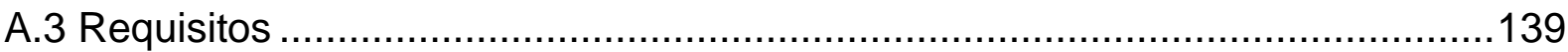

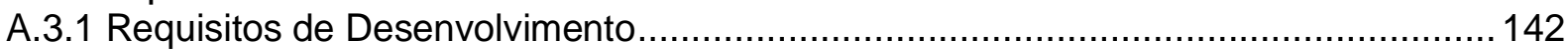

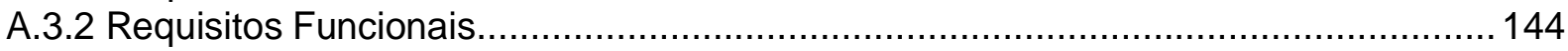

A.3.3 Requisitos de Apresentação, Usabilidade e Fatores Humanos................................. 147

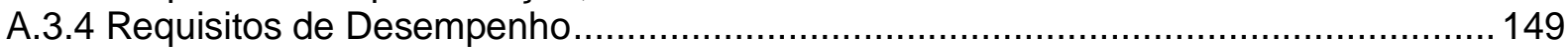

A.3.5 Requisitos Operacionais e de Ambiente ……………............................................ 150

A.3.6 Requisitos de Manutenção e Suporte .................................................................... 152

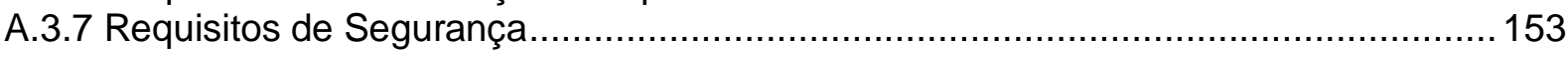

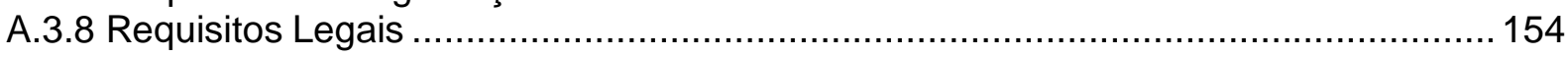

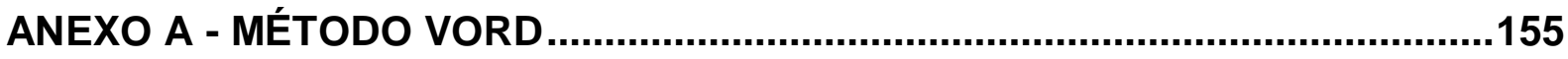

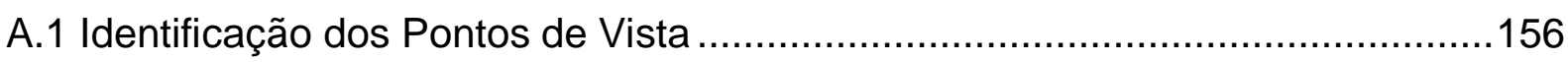

A.2 Documentação dos Pontos de Vista .......................................................156

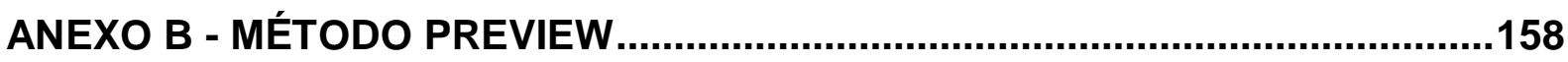

ANEXO C - MÉTODO VOLERE

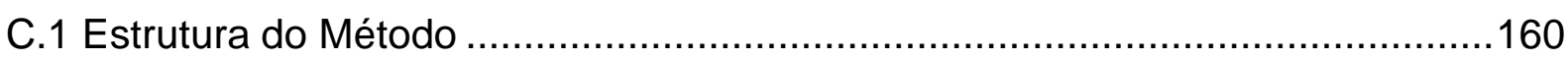

C.2 Identificação dos Eventos e Casos de Uso.................................................161

C.2.1 Casos de Uso do Negócio ............................................................................. 162

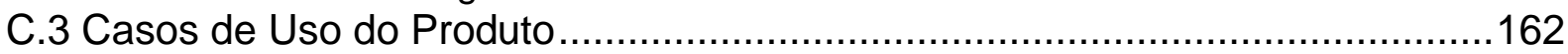

C.4 Levantamento e Definição dos Requisitos ..................................................162

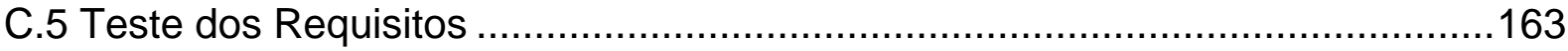




\section{INTRODUÇÃo}

O mercado brasileiro de transporte rodoviário de cargas apresenta cada vez mais competitividade, exigindo que as empresas transportadoras otimizem seus custos logísticos, e também ofereçam serviços de alta qualidade para seus usuários. Para isso, é imprescindível a utilização de ferramentas tecnológicas capazes de fornecer informações confiáveis sobre as operações realizadas pela sua de frota ${ }^{1}$ durante as viagens. O conhecimento do tempo real de deslocamento entre pontos, e de desvios da rota prevista, pode ajudar uma empresa a melhorar seus procedimentos logísticos e assim melhorar os seus resultados.

Sistemas sofisticados para gerenciamento de frotas que possibilitam desde a localização geográfica exata de um veículo, até o acionamento remoto de travas e dispositivos de segurança, são comercializados no Brasil. Atualmente, a maioria destes sistemas tem um custo muito elevado, o que inviabiliza sua utilização por grande parte da frota brasileira.

Um sistema que monitore e forneça dados sobre as viagens executadas por uma frota a um custo baixo, pode atender à grande maioria das empresas deste mercado. Este trabalho define os requisitos necessários para este sistema, através da aplicação de métodos e técnicas da Engenharia de Requisitos.

O escopo desta proposta é limitado ao estudo e aplicação dos processos e métodos apresentados na Engenharia de Requisitos, na elaboração de uma especificação de requisitos para um sistema de monitoramento de veículos no transporte rodoviário de cargas.

\footnotetext{
${ }^{1}$ O conjunto de veículos terrestres, aeronaves ou embarcações pertencentes a um mesmo país, companhia ou pessoa física, denomina-se frota (DICSEG 2006). Neste trabalho, o termo frota é utilizado para veículos terrestres rodoviários de transporte de carga.
} 


\subsection{Objetivos}

O objetivo desta dissertação é analisar os processos existentes para levantamento de requisitos de sistemas e definir um processo para o levantamento dos requisitos necessários para um sistema ${ }^{2}$ de monitoramento de veículos no transporte rodoviário de cargas. O processo escolhido é exercitado chegando a uma lista dos requisitos definidos.

Empresas pequenas e médias que necessitam de informações para o controle logístico de sua frota, mas que não tem justificativa financeira para um investimento pesado em sistemas de rastreamento desenvolvidos para grandes frotas poderão se beneficiar de uma especificação mais adequada a essa aplicação.

Para a elaboração deste trabalho, pretende-se aplicar algumas das técnicas e métodos definidos na Engenharia de Requisitos.

\subsection{Justificativa}

Atualmente, o custo de ferramentas tecnológicas para o monitoramento de veículos é elevado, e a grande maioria das pequenas e médias empresas não tem capacidade financeira para suportar este investimento.

Este trabalho descreve o levantamento e propõe uma lista de requisitos para um sistema de monitoramento de veículos que forneça informações sobre um veículo durante uma viagem. O custo de implantação deste sistema deverá ser muito inferior ao dos sistemas de rastreamento existentes no mercado. Para isso, não deverá utilizar tecnologias de comunicação via satélite, que elevam muito o custo do sistema.

\footnotetext{
${ }^{2}$ Sistema é uma coleção significativa de componentes inter-relacionados, que trabalham em conjunto para atingir um objetivo (SOMMERVILLE, 2004, p. 18).
} 


\subsection{Metodologia}

A metodologia utilizada para a condução deste trabalho, consistiu nas seguintes etapas:

1. Pesquisa Bibliográfica: caracterizada, basicamente, por pesquisas em livros técnicos, revistas, jornais, artigos especializados;

2. Definição da Proposta: através do levantamento dos sistemas disponíveis no mercado e dos problemas relatados por algumas empresas, foi definido o escopo deste trabalho;

3. Embasamento Teórico: esta etapa consistiu no estudo de métodos e técnicas da Engenharia de Requisitos, visando sua aplicação no levantamento e definição de requisitos para o sistema proposto;

4. Elaboração da Proposta: esta etapa consistiu em aplicar as metodologias pesquisadas para o levantamento e a elaboração da especificação de requisitos para o sistema de monitoramento de veículos.

\subsection{Terminologia}

Para uma melhor leitura e compreensão dos próximos capítulos, este item define os termos utilizados com freqüência neste trabalho:

- Levantamento de Requisitos: É a captura das necessidades e aspirações de todas as partes envolvidas (desenvolvedores, clientes e usuários) em relação ao sistema a ser desenvolvido. Utiliza diversas técnicas e metodologias para facilitar, ordenar e melhorar a coleta de informações. Faz parte da fase inicial do processo de Engenharia de Requisitos.

- Definição de Requisitos: Corresponde a uma listagem macro de informações e serviços que o sistema deve realizar e disponibilizar, escrita em linguagem natural (da forma como foram coletadas das 
partes envolvidas). Faz parte da fase intermediária do processo de Engenharia de Requisitos.

- Especificação de Requisitos: É um detalhamento dos requisitos já definidos para o sistema, descritos em um documento de forma clara e precisa. Faz parte da fase final do processo de Engenharia de Requisitos, e serve como fonte de informações para a especificação do sistema.

\subsection{Estrutura do trabalho}

Além do capítulo de Introdução, esta dissertação conta com mais sete capítulos.

O capítulo 2 descreve o panorama do transporte de cargas no Brasil, ressaltando a importância do transporte rodoviário no cenário brasileiro.

O capítulo 3 relata alguns conceitos, definições e métodos da Engenharia de Requisitos.

O capítulo 4 apresenta o levantamento dos requisitos de um sistema de monitoramento para veículos de transporte rodoviário de cargas.

O capítulo 5 detalha a definição dos requisitos para o sistema proposto.

O capítulo 6 valida os requisitos até então levantados e definidos.

O capítulo 7 apresenta as considerações finais deste trabalho. 


\section{TRANSPORTE DE CARGAS NO BRASIL}

O transporte de cargas é um mecanismo fundamental no processo produtivo de qualquer sociedade, pois sem ele os bens produzidos não poderiam chegar ao consumidor final.

Os principais sistemas utilizados para o transporte de cargas são:

- Terrestre: formado pelos transportes rodoviário, ferroviário e dutoviário;

- Aquaviário: composto dos transportes marítimo, fluvial e lacustre, realizados respectivamente em mares e oceanos, rios e lagos;

- Aeroviário.

O transporte terrestre é caracterizado quando o deslocamento acontece por terra firme, com as seguintes variações: rodoviária (sobre rodas), ferroviária (sobre trilhos) e dutoviária (através de condutos fechados). O transporte aquaviário acontece quando o veículo se desloca sobre o meio líquido, estando assim incluídos os transportes marítimo, fluvial e lacustre. Finalmente, o transporte aeroviário é a modalidade de transporte que acontece pelo ar.

Por questão de representatividade no cenário mundial, os seguintes tipos de transportes são chamados modais básicos do sistema de transporte: aéreo, aquaviário, dutoviário, ferroviário, rodoviário.

Nos países desenvolvidos, seja de grande ou pequena extensão territorial, o transporte de cargas é feito predominantemente por meio de ferrovias e hidrovias. Esses tipos de transporte proporcionam uma maior capacidade de carga e são muito mais econômicos.

Em países subdesenvolvidos, por influência da indústria automobilística e pela falta de investimento em infra-estrutura ferroviária e portuária, verifica-se o predomínio do transporte rodoviário.

No Brasil, na década de 50, com o novo modelo de industrialização no governo do presidente Juscelino Kubitschek, a indústria automobilística assumiu um papel importante no processo de industrialização. A construção de rodovias, de Brasília e a 
implantação da indústria automobilística viabilizam a criação do sistema de Transportes Rodoviário de Cargas (TRC), em substituição ao até então predominante sistema ferroviário (MACOHIN, 2001, p. 63).

O Transporte Rodoviário de Cargas é o modal mais utilizado no Brasil, representando mais de $60 \%$ das operações de transportes realizadas no território nacional.

A Tabela 1 mostra um comparativo entre as operações realizadas em cada um dos modais no Brasil e nos EUA.

Tabela 1 - Divisão dos modais de transporte no Brasil e nos EUA

\begin{tabular}{lll}
\hline \multicolumn{3}{c}{ Modais de Transporte $\left(\mathrm{TKm}^{3}\right)$} \\
\hline & Brasil & EUA \\
\hline Rodoviário & $62 \%$ & $26 \%$ \\
\hline Ferroviário & $19 \%$ & $38 \%$ \\
\hline Aquaviário & $14 \%$ & $16 \%$ \\
\hline Dutoviário & $5 \%$ & $20 \%$ \\
\hline Aeroviário & $<1 \%$ & $<1 \%$ \\
\hline
\end{tabular}

Fonte: ANTT (março 2006)

\footnotetext{
${ }^{3}$ TKm é uma unidade de medida para Toneladas por Quilômetro.
} 


\subsection{Transporte Rodoviário de Cargas no Brasil}

Pesquisas da Confederação Nacional do Transporte mostram que a participação do setor de transportes na economia brasileira é significativa (CNT, 2006):

- Valor adicionado pelo setor de transportes no PIB (\%): 4,4\%;

- Valor adicionado pelo setor de transportes no PIB (R\$:) R\$ 42 bilhões;

- Empregos diretos gerados: 1,2 milhões;

- Total de carga movimentada por ano (em TKU4): 746 bilhões.

Segundo a CNT, a atividade de transporte rodoviário de carga no Brasil envolve mais de 60 mil empresas, aproximadamente 700 mil transportadores autônomos registrados, totalizando 2,5 milhões de trabalhadores. A Tabela 2 apresenta alguns destes números.

Com uma frota estimada em 1,4 milhões de caminhões, o transporte rodoviário é responsável por $60,5 \%$ de toda movimentação de carga no Brasil, com faturamento anual de $\mathrm{R} \$ 21,5$ bilhões.

Tabela 2 - Quantidade de veículos por tipo de Transportador

Transportadores Habilitados por Tipo de Transportador

\begin{tabular}{lcc}
\hline Tipo do Transportador & Registros Emitidos & Veículos \\
\hline Autônomo & 669.733 & 858.915 \\
\hline Empresa & 122.528 & 649.117 \\
\hline Cooperativa & 593 & 7.765 \\
\hline Totais & 792.854 & 1.515 .797 \\
\hline
\end{tabular}

Fonte: ANTT (março 2006)

Além dos fatores históricos da influência da indústria automobilística, outros fatores colaboram para o predomínio e o avanço do transporte rodoviário no Brasil:

\footnotetext{
${ }^{4}$ TKU é uma unidade de medida para Toneladas por Quilômetro Útil.
} 
- Histórico de serviço e capacidade insuficiente dos outros modais;

- Prioridade nos investimentos governamentais em rodovias;

- Falta de regulação ou desrespeito à mesma, tais como: normas de trabalho, idade ou manutenção de veículos, peso máximo por eixo;

- Excesso de oferta e preços baixos.

Apesar do volume expressivo, o setor vem convivendo há vários anos com graves problemas que têm afetado o desempenho das empresas e a qualidade dos serviços oferecidos.

Circulando em vias deterioradas, às vezes sem condições mínimas para suportar os tráfegos pesados de cargas e passageiros, a frota nacional é submetida a um intenso processo de desgaste, com o conseqüente sucateamento de máquinas, veículos, equipamentos, e de todos os profissionais que utilizam e se relacionam direta ou indiretamente com este modal.

Em 2000, o Ministério dos Transportes e a Confederação Nacional do Transporte elaboraram um estudo sobre a atual situação do transporte rodoviário de cargas brasileiro. Alguns números significativos desta pesquisa:

- Existência de uma malha rodoviária de 1,5 milhões de km, dos quais apenas $10 \%$ pavimentados;

- Desaceleração da taxa de expansão da malha física pavimentada de $3200 \mathrm{~km} / \mathrm{ano}$, na década de 70, para 783 km/ano na década de 90;

- Situação precária das malhas federal e estadual em meio a um lento processo de privatização das rodovias;

- Rápida evolução da frota nacional de veículos entre os anos 60 e 80, registrando uma taxa média anual de 12,3\%, enquanto entre 80 e 90 foi apenas de 6,12\% ao ano. A frota total de veículos em 1994 era de 1.123 .428 divididos em $25,1 \%$ de veículos leves, $35,5 \%$ médios, $24,2 \%$ semi-pesados e $15,2 \%$ pesados;

- O envelhecimento da frota é preocupante: mais de $45 \%$ do total transportado é realizado por caminhões com idade superior a 8 anos, 
sendo que a frota mais envelhecida está nas mãos dos transportadores autônomos (62,8\% dos caminhões têm mais de 8 anos de fabricação).

O envelhecimento da frota é uma das principais conseqüências do aumento de custo decorrente da precariedade da infra-estrutura rodoviária. Ou seja, a precariedade da infra-estrutura para o transporte (principalmente estradas de boa qualidade) aumenta o custo do quilômetro rodado, e como conseqüência o transportador tem muito reduzida a sua capacidade de investimento na renovação da frota.

Historicamente, o governo federal do Brasil tem investido pouco em nossas estradas. Mais recentemente, o governo lançou a idéia da parceria público-privada, a fim de atrair investimento privado para essa área. Mas esse processo tem se mostrado lento, principalmente por causa da complexidade do mesmo. Portanto, no curto prazo, as perspectivas não devem mudar em relação à infra-estrutura para o setor.

Até aqui, identificamos um primeiro pano de fundo sobre o transporte rodoviário brasileiro. Problemas estruturais levam a um transporte de custo elevado.

Além desses problemas estruturais que levam a um aumento no custo do transporte, há ainda o problema do roubo de cargas, que tem se agravado a cada ano. Esta realidade leva a uma segmentação do mercado por tipo de carga, ditada pelas empresas de seguro, explicado a seguir. No mercado de seguros, uma carga com alto valor agregado (AVA) tem um alto risco de roubo, e uma carga com baixo valor agregado (BVA) tem baixo risco de roubo. A Figura 1 mostra um gráfico das porcentagens de roubo de acordo com o tipo da mercadoria.

Como conseqüência do crescente roubo de cargas, houve um aumento dos valores de seguro para cobertura de cargas, seguido de um movimento mitigador de risco liderado pelas empresas seguradoras. 


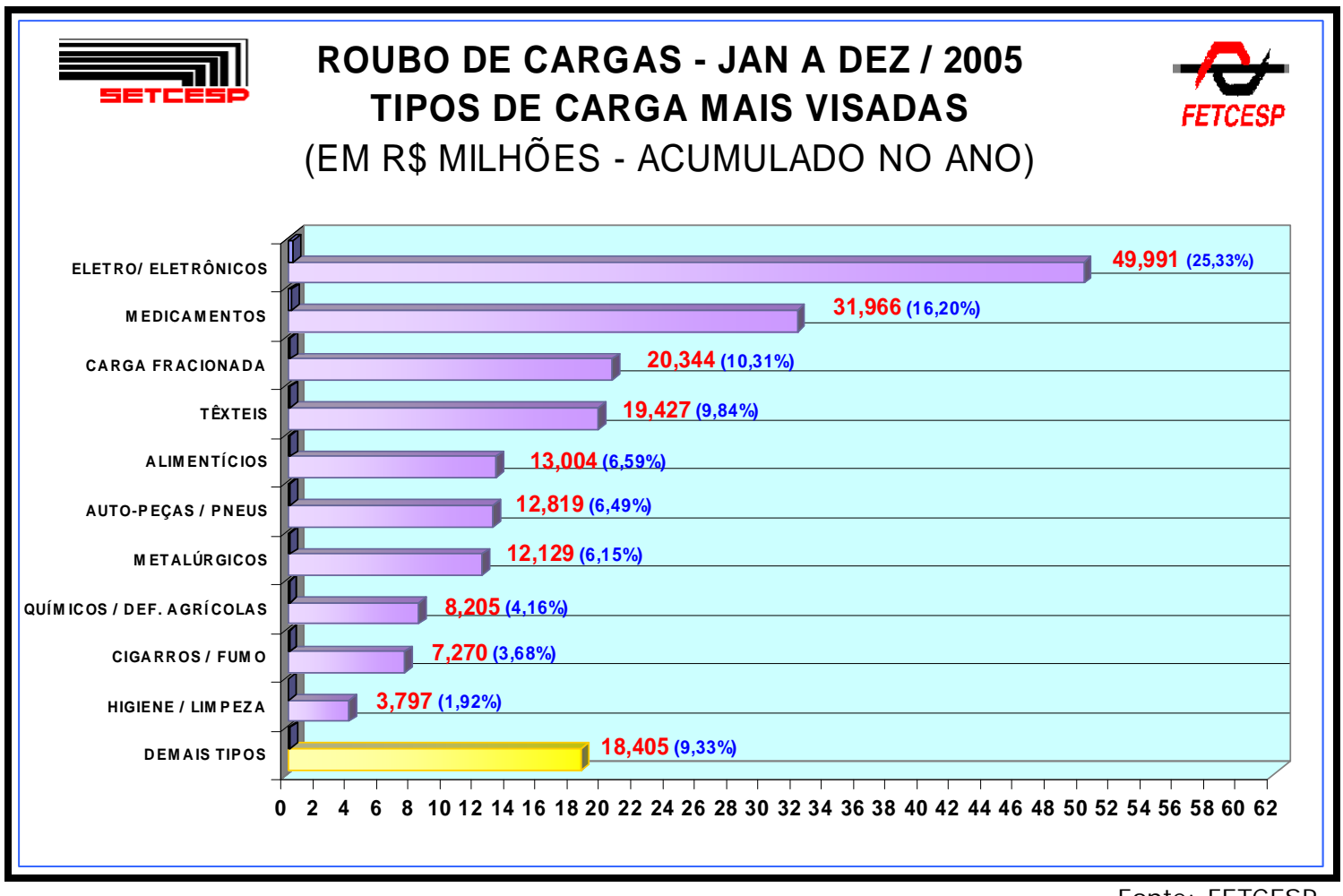

Figura 1 - Tipos de carga mais visadas para roubo

Esse movimento seguinte foi a exigência, por parte das seguradoras, de que as transportadoras passassem a rastrear o transporte de carga de alto valor agregado. Atualmente, para fazer o seguro desse tipo de transporte, as seguradoras exigem que o caminhão tenha os equipamentos de rastreamento por satélite (até com escolta particular, em alguns casos), e, além disso, como já explicado, cobram um prêmio maior pelo seguro.

Como efeito colateral e benéfico desse movimento, as empresas que participam do mercado de transporte de risco perceberam as vantagens logísticas de ter um sistema de rastreamento. Essas empresas passaram a usar esse sistema para otimizar rotas e controlar melhor a frota, racionalizando os custos de transporte.

Devido ao alto investimento necessário, somente empresas com boa estrutura financeira e capital disponível podem contar com esse tipo de sistema. Atualmente, estima-se que $85 \%$ da frota brasileira não possua sistema de rastreamento.

O custo de transporte no Brasil é elevado e o roubo de cargas piora ainda mais a situação. No entanto, por causa do roubo de cargas, empresas com melhor estrutura financeira investiram em sistemas de rastreamento, e conseguiram como benefício 
colateral a otimização dos custos logísticos. Isso tornou tais empresas ainda mais competitivas no mercado de transportes.

Mas ainda é uma realidade restrita a poucas empresas, apenas $15 \%$ dos participantes do mercado nacional. Do ponto de vista logístico, os transportadores que não tem acesso a sistemas de rastreamento precisam de algum tipo de solução tecnológica que forneça as informações básicas para a otimização dos transportes, tornando-as mais competitivas. Esse assunto será explorado a seguir.

\subsection{Tecnologia da Informação e o TRC}

$\mathrm{Na}$ era da informação e de alta competitividade no mercado, as organizações necessitam de produtos e sistemas que ofereçam soluções rápidas, de qualidade, e de um serviço de alto valor agregado a seus clientes. Investir na melhoria dos produtos e serviços promove a integração entre a empresa e o mercado consumidor, o que é de fundamental importância para a sustentação e o desenvolvimento das organizações.

Os avanços tecnológicos dos últimos anos têm garantido o recebimento de informações rápidas e precisas, o que tem norteado cada vez mais a tomada de decisões nas empresas que adotam estas tecnologias.

Diante da grande concorrência do mercado e visando uma melhora no atendimento das várias regiões do Brasil e do Mercosul, o setor de transporte rodoviário de cargas tem investido muito em sistemas de informação, que possibilitem uma melhora nos prazos e nas condições de conservação das mercadorias entregues. Estes sistemas vão desde controles de estoque dos armazéns até logísticas de coleta e distribuição das mercadorias.

O conceito de "logística" pode ser definido como:

O processo de gerenciar estrategicamente a aquisição, movimentação e armazenagem de materiais, peças e produtos acabados (e os fluxos de informações correlatas), através da organização e seus canais de marketing, de modo a poder maximizar as lucratividades presentes e futuras através do atendimento dos pedidos a baixo custo (CHRISTOPHER, 1997, p. 2). 
Para Christopher (1997, p.120), o gerenciamento logístico pode proporcionar uma fonte de vantagem competitiva, ou seja, uma posição de superioridade duradoura sobre os concorrentes, em termos de preferência do cliente, pode ser alcançada através da logística.

A utilização da tecnologia de informação no gerenciamento logístico de uma empresa é um componente fundamental que pode garantir sua competitividade no mercado. Podemos observar ganhos significativos na implementação de ferramentas tecnológicas que privilegiam as operações, e garantem assim um nível elevado de qualidade aos processos realizados.

Bowersox e Closs (1996, p. 186) ressaltam a necessidade de informações rápidas, em tempo real, e com alto grau precisão para uma gestão eficiente da logística e da cadeia de suprimentos, alegando as seguintes razões:

Primeiro, clientes entendem que informações do andamento de uma ordem, disponibilidade de produtos, programação da entrega e dados do faturamento são elementos fundamentais do serviço ao cliente. Segundo, com a meta de redução do estoque em toda a cadeia de suprimentos, os executivos percebem que com informações adequadas, eles podem, efetivamente, reduzir estoques e necessidades de recursos humanos. Se o planejamento de necessidades for feito com informações mais recentes, consegue-se reduzir estoques através da minimização das incertezas da demanda. Em terceiro, a disponibilidade de informações aumenta a flexibilidade com respeito, a saber, quanto, quando e onde os recursos podem ser utilizados para obtenção de vantagem estratégica.

Dessa forma, é de suma importância que o segmento de transporte rodoviário de cargas explore as possibilidades oferecidas a partir da aplicação da tecnologia de informação na busca de sua efetividade. A informação oferece a possibilidade de estabelecer a vantagem mercadológica através de processos decisórios mais precisos e velozes, disponibilizando dados corretos no momento e local exatos.

O posicionamento relativo de uma empresa aos demais concorrentes é uma questão fundamental em uma estratégia competitiva. É nesse contexto que o papel da informação torna-se ainda mais fundamental para o sucesso das organizações, pois, coletar os dados e gerar as informações necessárias para uma tomada de decisão estratégica pode ser o diferencial num mercado altamente competitivo.

Segundo Porter (1991, p. 22), "a essência da formulação de uma estratégia competitiva é relacionar uma companhia ao seu meio ambiente". Existem forças que 
conduzem as empresas a tomarem atitudes e decisões que minimizem os impactos que possam causar distúrbios no seu entorno. As forças externas, em geral, afetam todas as organizações. O ponto básico encontra-se nas diferentes habilidades dos gestores em lidar com elas. Porter (1991, p. 24) afirma que o estágio da competição em que se encontra uma empresa depende de cinco forças básicas:

1. Ameaça de entrada de novas empresas no setor;

2. Ameaça de produtos substitutos que possam ter impacto no negócio;

3. Poder de negociação dos compradores/clientes;

4. Poder de negociação dos fornecedores;

5. Rivalidade entre os atuais concorrentes.

O impacto destas forças no negócio pode ser minimizado através de uma estratégia competitiva efetiva, que identifique e gerencie rapidamente estas forças.

Através da tecnologia e dos sistemas de informação, as empresas de transporte estão transpondo barreiras tecnológicas antes compreendidas às indústrias de produção de bens tangíveis e inserem no serviço prestado, vetores tecnológicos de competitividade e confiabilidade. As transações podem ser assistidas por mecanismos informatizados e beneficiadas com a redução significativa dos tempos de processamento. O controle logístico da frota é mais preciso, e o risco do transporte atenuado quando são utilizadas ferramentas modernas de rastreamento.

Através dessas ferramentas, viabiliza-se a obtenção de informações sobre o andamento das viagens executadas por seus veículos, a fim de permitir que a transportadora aprimore os seus procedimentos logísticos.

A seguir, são exploradas as características de um sistema de rastreamento de veículos.

\subsubsection{Sistemas de Rastreamento}

Os sistemas de rastreamento utilizam tecnologias que permitem o rastreamento e monitoramento remoto de veículos, através da coleta de informações de 
posicionamento e dos sensores existentes nestes veículos. São muitas as aplicações destes sistemas no gerenciamento de frota de caminhões ou de veículos, públicos ou particulares.

Uma das informações mais importantes em um sistema de rastreamento é a posição geográfica atual do veículo. Na grande maioria dos sistemas, esta informação é obtida através de um equipamento chamado GPS.

No final da década de 70, o Departamento de Defesa dos Estados Unidos desenvolveu um sistema de radionavegação chamado Navstar GPS (NAVigation System for Timing And Ranging Global Positioning System), com o objetivo de ser o principal sistema de navegação das forças armadas americanas. Conhecido atualmente apenas pela sigla GPS (Global Positioning System), este sistema tornouse disponível para uso civil em $1983^{5}$.

O GPS é uma ferramenta extremamente útil para todas as atividades que necessitam de posicionamento, tais como, as relacionadas à cartografia, meio ambiente, controle de frota de veículos, navegação aérea e marítima, geodinâmica, agricultura, etc. É baseado em uma constelação de 24 satélites operacionais (Navstar), em órbita a 20.200 quilômetros da superfície da Terra. A Figura 2 dá uma noção da disposição desta constelação.

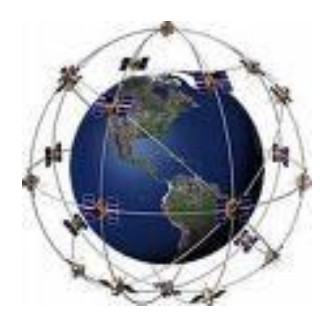

Figura 2 - Constelação Navstar

Estes satélites transmitem sinais que podem ser detectados por qualquer um que possua um receptor GPS, esteja ele na terra, no mar ou no ar. Através do processamento de sinais recebidos de vários satélites, o receptor GPS consegue calcular suas coordenadas geográficas naquele momento (latitude e longitude). Com

\footnotetext{
${ }^{5}$ Em 1983, quando um avião da companhia aérea Korean (vôo 007) foi derrubado pela defesa aérea, após ter se perdido sobre o território soviético, decidiu-se pela liberação da utilização do sistema GPS por civis.
} 
a disponibilização deste sistema para fins civis, começaram a surgir diversos produtos baseados nessa tecnologia, entre eles os sistemas de rastreamento.

Atualmente, os receptores de GPS são utilizados em todo o mundo nas mais diversas aplicações que necessitam monitorar posições: barcos, frotas de veículos, sistemas de transporte público, frotas de caminhões, etc. Durante a construção do túnel entre França e Inglaterra, os trabalhadores, que iniciaram as escavações simultaneamente nas duas extremidades, utilizavam aparelhos de GPS para obter a coordenada do ponto onde estavam escavando, para ter a certeza de que iriam se encontrar exatamente no meio (RAMADURAI, 2003, p. 8).

Os sistemas de rastreamento de veículos atuais consistem basicamente de um receptor GPS instalado no veículo, um computador de bordo e acessórios para o monitoramento e acionamento de travas e sensores. A cada informação sobre o veículo enviada para a central de gerenciamento, o computador de bordo informa as coordenadas geográficas atuais, calculadas através do processamento dos dados recebidos do GPS.

O meio de comunicação utilizado para troca de informações entre o veículo e a central de gerenciamento varia de acordo com o tipo de sistema de rastreamento. As tecnologias de comunicação mais utilizadas são: via satélite e via celular.

\subsubsection{Sistema de Rastreamento Via Satélite}

Este sistema transmite e recebe sinais, de forma bidirecional, através de satélites geoestacionários $^{6}$ ou de baixa órbita ${ }^{7}$. Seja qual for o tipo do satélite, sua utilização depende que o veículo tenha visada para o céu aberto, o que em alguns casos não é possível (dentro de garagens cobertas, túneis, etc.).

São vários os satélites utilizados atualmente no Brasil para estes sistemas:

\footnotetext{
${ }^{6}$ Um satélite do tipo geoestacionário é aquele que completa sua volta ao redor da Terra em 24 horas, ou seja, tem a mesma velocidade angular que a Terra. Portanto, ele está sempre sobre o mesmo ponto do planeta: para um observador à superfície é como se ele não se deslocasse.

7 Os satélites da baixa órbita (Low Earth Orbit) estão localizados a cerca de $830 \mathrm{Km}$ e $975 \mathrm{Km}$ de altitude (por isso são denominados de baixa órbita), e formam o sistema chamado Orbcomm®, composto por 42 satélites.
} 
- Geoestacionários: Brasilsat, Irmasat;

- Baixa Órbita: Orbcomm, Globalstar e Iridium.

O Brasilsat, por exemplo, é um satélite geoestacionário, cuja órbita está em 38.000 $\mathrm{km}$ de altitude. Trata-se do mesmo satélite que é utilizado para os sinais de televisão.

Qualquer que seja o tipo de satélite utilizado, um sistema de rastreamento via satélite proporciona a transmissão e recepção de dados, permitindo, inclusive, que o motorista envie textos para a sua central, informando ocorrências, rotas, e outras solicitações. Devido a sua cobertura nacional, a qualquer momento é possível obterse a posição geográfica de um veículo.

As desvantagens dos sistemas de rastreamento que utilizam comunicação via satélite são o alto custo e a dificuldade nas operações quando o veículo está embaixo de uma cobertura qualquer ou dentro de um túnel (sem visada para o satélite).

\subsubsection{Sistema de Rastreamento Via Celular}

Este sistema utiliza a tecnologia GSM/GPRS para a troca de informações com a central de gerenciamento. GSM (Global System for Mobile Communications) é o padrão de tecnologia móvel mais popular para telefones celulares do mundo. O GPRS (General Packet Radio Service) é uma tecnologia que aumenta as taxas de transferência de dados nas redes GSM existentes, permitindo o transporte de dados por pacotes (comutação por pacotes).

O computador de bordo instalado no veículo envia e recebe informações da central de gerenciamento através de pacotes de dados transmitidos através de uma conexão GPRS.

Este tipo de sistema tem um custo inferior ao que opera com satélite, e permite o rastreamento com boa precisão. Embora a transmissão de dados, em geral, não seja prejudicada em ambientes cobertos, sua utilização é mais indicada nas áreas 
urbanas, já que sua comunicação com a central de rastreamento fica restrita às áreas de cobertura das operadoras de telefonia celular.

Em geral, estes sistemas possuem um receptor GPS para a obtenção das coordenadas geográficas do veículo. Entretanto, alguns modelos não utilizam esta tecnologia, e utilizam as estações radio base para calcular esta posição.

As operadoras de telefonia celular distribuem, pelas regiões geográficas, antenas com rádios transmissores para o funcionamento dos celulares, que são conhecidas como Estações Rádio Base (ERB). O cálculo da posição geográfica aproximada do veículo é feito através de um referenciamento geográfico destas ERBs. Nesse caso, o posicionamento do veículo não é tão preciso quanto aquele utilizando o GPS, mas tem como atrativo seu custo reduzido.

\subsubsection{Características de um Sistema de Rastreamento}

Seja qual for a tecnologia de comunicação utilizada entre o sistema de rastreamento e a central de gerenciamento, a maior vantagem de qualquer sistema de rastreamento está, sem dúvida, relacionada às funcionalidades de segurança. $A$ maioria dos sistemas de rastreamento possui sensores e atuadores acoplados aos veículos, através dos quais obtêm-se informações importantes:

- Atualização da posição geográfica em curtos intervalos de tempo;

- Estado da ignição do veículo (ligada, desligada);

- Indicação de abertura de portas e da porta do baú;

- Alarme de botão de pânico acionado pelo motorista em caso de assalto;

- Possibilidade de envio e recepção de mensagens de texto para o motorista;

- Bloqueio de combustível e travamento das portas feito remotamente pela central.

Alguns sistemas de rastreamento têm funcionalidades de mais alto nível e podem fornecer também: 
- Indicação de desvio da rota prevista;

- Indicação de entrada e saída em uma zona considerada de alto risco de roubo;

- Indicação de parada em um ponto não previsto; e,

- Indicação de saída de um ponto em horário não previsto.

Pelas funcionalidades disponibilizadas para as transportadoras, pode-se perceber que, além do aumento da segurança, os sistemas de rastreamento trazem muitos benefícios para o gerenciamento logístico. Entretanto, os equipamentos e as tecnologias envolvidas nestes sistemas ainda despendem um investimento muito elevado $^{8}$, o que se justifica financeiramente somente para empresas que transportam produtos de alto valor agregado.

\subsubsection{Opções Existentes no Mercado Brasileiro}

No gerenciamento logístico do transporte rodoviário de carga, as principais informações são a data e hora de saída e chegada do veículo, e os horários e pontos onde ele fez alguma parada, prevista ou imprevista. Este controle é muito importante para que a empresa transportadora possa fornecer informações precisas aos seus clientes, e para que possam ser tomadas as devidas providências para a melhora do serviço (mudança da rota utilizada, troca de motorista, etc.).

Como alternativa ao rastreamento de veículos, que ainda representa alto custo para as empresas, já existem, no mercado, empresas que oferecem soluções alternativas, como, por exemplo, o monitoramento de viagens por cartão magnético.

O sistema de monitoramento por cartão é composto por terminais de coleta de dados instalados em postos de abastecimento ou postos de controle espalhados ao longo da rota utilizada pelos veículos. Ao parar em um destes pontos, o motorista do veículo passa o cartão magnético da empresa no terminal de coleta de dados, e

\footnotetext{
${ }^{8}$ De acordo com o tipo de comunicação utilizado, atualmente, a instalação de um sistema de rastreamento para um veículo varia de $R \$ 600,00$ à $R \$ 7.600,00$, além do custo mensal do serviço que pode variar de $R \$ 35,00$ a $R \$ 250,00$ (valores de junho/2006).
} 
digita o motivo de sua parada naquele ponto (abastecimento, refeição, carga, descarga, etc.). O terminal, conectado a rede telefônica, faz uma ligação para a central de monitoramento para enviar os dados, informando a identificação do motorista, data, hora e motivo da parada. Para efeito de controle logístico, essas são as mesmas informações que seriam enviadas através de um sistema de rastreamento por satélite ou celular, mas baseado em tecnologia mais acessível a transportadoras com capacidade de investimento limitada.

No entanto, mesmo com custo reduzido ${ }^{9}$, este tipo de ferramenta está muito sujeita a erros humanos no processo. Várias situações possíveis geram imperfeição no método, dentre elas as paradas em postos de abastecimento não previstos na rota ou esquecimento do motorista de passar o cartão ou ainda a digitação da função errada no terminal.

Existe uma lacuna em tecnologia de monitoramento a ser preenchida por um sistema que alie custo e qualidade da informação. Pode-se, desde já, prever que, qualquer que seja a arquitetura que se venha a adotar neste sistema, é conveniente que parte dele seja instalada no veículo e atue de forma autônoma das ações do motorista.

Equipamentos e sistemas instalados e operados em veículos têm características e necessidades específicas, cujo estudo é apresentado no próximo item.

\subsubsection{Sistemas Embarcados}

Segundo o site "Tech Dictionary" (TECH, 2007), um sistema embutido, do inglês “Embedded System”, é:

Um tipo de sistema computacional dedicado a um propósito específico, utilizado dentro de um dispositivo. Por exemplo, um forno de microondas contém um sistema embutido que recebe comandos de um painel, e executa as operações indicadas.

Diversos autores preferem chamá-los de sistemas embarcados, já que estes sistemas começaram a ser utilizados em maior escala em aplicações para veículos, como automóveis, barcos e aeronaves. Considerando que esta proposta trata de um

\footnotetext{
${ }^{9} \mathrm{O}$ custo mensal de cada terminal neste tipo de sistema é de aproximadamente $\mathrm{R} \$ 50,00$ (valor de junho/2006).
} 
sistema para veículos de transporte rodoviário de carga, adotar-se-á o termo sistemas embarcados.

Um sistema embarcado é uma combinação de hardware e software que formam juntos um componente de uma máquina maior, e cuja operação independe da intervenção humana. A maioria dos aparelhos eletrônicos, eletrodomésticos e dos carros fabricados atualmente, possui um ou mais programas de software embarcados.

A fabricação e distribuição destes produtos, em larga escala, exigem que o hardware e o software neles inseridos tenham um alto grau de confiabilidade e que o índice de falhas e manutenção tenda a zero (WOLF, 2001, p. 2).

O desenvolvimento de um sistema embarcado é complexo, pois envolve questões de portabilidade, confiabilidade, segurança, limite de tamanho (para o software, hardware e memória utilizada) e limite de consumo de potência sem perda de desempenho (WOLF, 2001, p. 5). Estas características especiais são detalhadas no próximo item.

\subsubsection{Características Principais}

Sistemas embarcados apresentam diversas características que os diferenciam de outros sistemas integrados. Dentre essas características pode-se destacar:

- Alta integração de os módulos de hardware e software;

- Voltados para uma aplicação específica;

- Interface com o mundo exterior bem definida;

- Restrições e requisitos fortes e bem definidos: tolerância à falhas, condições de ordem temporal (desempenho), segurança, robustez, custos, etc.

Uma falha é uma condição anômala, causada por erros de projeto, problemas de fabricação ou distúrbios externos. Tendo em mente que falhas são inevitáveis, procura-se atribuir aos sistemas a capacidade de tolerar a ocorrência de falhas apresentando o funcionamento desejado, ou pré-definido, evitando assim danos 
materiais ou a outras pessoas. A tolerância à falhas é uma característica importante para os sistemas embarcados e, se utilizada em sistemas com baixas taxas de falhas, ou alta confiabilidade, resulta em sistemas com maior dependabilidade.

A expressão dependabilidade é utilizada para indicar a qualidade do serviço fornecido por um dado sistema e a confiança depositada neste serviço. É uma medida de qualidade que abrange os conceitos de confiabilidade, disponibilidade, segurança, desempenho, mantenabilidade e testabilidade (PRADHAN, 1996, p. 2).

As regras e os requisitos para a garantia da dependabilidade de um produto são definidos na norma ABNT NBR 14857-2 (2002, p. 3). A Tabela 3 mostra a definição de cada um destes conceitos:

Tabela 3 - Medidas de dependabilidade

\begin{tabular}{|c|c|}
\hline CONCEITO & DESCRIÇÃO \\
\hline $\begin{array}{l}\text { Confiabilidade } \\
\text { (Reliability) }\end{array}$ & $\begin{array}{l}\text { É a probabilidade que um sistema continue operando } \\
\text { corretamente do início ao fim de um determinado intervalo de } \\
\text { tempo. }\end{array}$ \\
\hline $\begin{array}{l}\text { Disponibilidade } \\
\text { (Availability) }\end{array}$ & $\begin{array}{l}\text { É a probabilidade de um sistema estar operando corretamente } \\
\text { em um dado instante. }\end{array}$ \\
\hline $\begin{array}{l}\text { Segurança } \\
\text { (Safety) }\end{array}$ & $\begin{array}{l}\text { É a probabilidade de um sistema estar operando em uma } \\
\text { condição segura. Uma condição insegura é aquela onde o } \\
\text { sistema, em conjunto com outros fatores do ambiente onde está } \\
\text { sendo executado, causará um acidente. }\end{array}$ \\
\hline $\begin{array}{l}\text { Segurança } \\
\text { (Security) }\end{array}$ & $\begin{array}{l}\text { O sistema deve estar preparado contra falhas que afetem a } \\
\text { privacidade, autenticidade e a integridade dos dados. }\end{array}$ \\
\hline $\begin{array}{l}\text { Desempenho } \\
\text { (Performability) }\end{array}$ & $\begin{array}{l}\text { É a probabilidade do desempenho de um sistema ser maior ou } \\
\text { igual a um determinado nível em um dado intervalo de tempo. }\end{array}$ \\
\hline $\begin{array}{l}\text { Mantenabilidade } \\
\text { (Maintainability) }\end{array}$ & $\begin{array}{l}\text { É a probabilidade de que, após uma falha, um sistema volte a } \\
\text { operar em um determinado intervalo de tempo. Ela mede a } \\
\text { facilidade que um sistema pode ser reparado. }\end{array}$ \\
\hline $\begin{array}{l}\text { Testabilidade } \\
\text { (Testability) }\end{array}$ & $\begin{array}{l}\text { É uma medida da facilidade de se caracterizar um sistema } \\
\text { através dos testes. Inclui a facilidade de execução dos testes e } \\
\text { sua efetiva observação. }\end{array}$ \\
\hline
\end{tabular}


Os sistemas de defesa e controle de tráfego aéreo instalados nos aviões, são exemplos de sistemas embarcados que necessitam de um alto grau de confiabilidade e disponibilidade.

Alguns fatores que dificultam o desenvolvimento de um sistema embarcado:

- Restrição no ambiente de desenvolvimento: As ferramentas disponíveis para o desenvolvimento de software para sistemas embarcados são, geralmente, específicas e têm um custo elevado. A depuração do código é mais trabalhosa do que a de um programa que será utilizado em um microcomputador, por exemplo;

- Complexidade dos testes: Os testes iniciais de um sistema embarcado geralmente envolvem a criação de protótipos para geração de dados em quantidades e tempos variados;

- Interface com o usuário é limitada: Sistemas embarcados normalmente não têm teclado, nem monitor de vídeo. Isto implica na aplicação de conceitos e teorias de usabilidade na sua definição e implementação.

Projetar e implementar um sistema embarcado é um desafio, tendo em vista que seus requisitos incluem linhas críticas e diversas funcionalidades (WOLF 2001, p. 8). As características especiais descritas até aqui, aliadas às pressões mercadológicas como, por exemplo, tempo e custo de projeto, impõem a necessidade de uma análise de requisitos apropriada.

Devido as suas características, alguns autores ressaltam diversos requisitos que devem ser observados no projeto de um sistema embarcado.

Sistemas embarcados são essencialmente sistemas de tempo real. Um sistema é dito de Tempo Real quando ele responde a entradas, e fornece informações, rápido o suficiente para atender os requisitos do hardware ou do usuário (SCHULTZ, 1999, p. 23). Na definição dos requisitos do sistema deve-se fazer uma estimativa do seu comportamento no tratamento dos eventos internos e externos, síncronos e assíncronos, para que se mantenha um desempenho mínimo, mesmo nos piores casos. 
Um sistema embarcado deve ter proteções contra os ambientes inóspitos, tais como, aqueles em que esteja exposto ao excesso de calor, à vibração, à flutuação da energia elétrica, à corrosão, etc. Em tais ambientes, o risco de falha é maior, o que demanda um bom projeto. Além disso, os sistemas embarcados geralmente apresentam restrições de tamanho, peso e custo, que devem ser levadas em conta na definição da arquitetura do sistema.

No próximo capítulo são apresentadas algumas características da Engenharia de Requisitos como tem sido chamada a parte da engenharia de software responsável pela definição dos requisitos dos sistemas. 


\section{ENGENHARIA DE REQUISITOS}

Um sistema que atenda a grande maioria das necessidades dos usuários tem grandes chances de ser um sistema de sucesso. Estudos recentes comprovam que os problemas relacionados aos requisitos do sistema afetam boa parte das organizações que desenvolvem e utilizam sistemas de software (ESPITI, 1996, p. 6). Erros em requisitos detectados apenas depois do software implementado são até 20 vezes mais caros de se corrigir que qualquer outro tipo de erro, e até 200 vezes mais custosos do que seriam se corrigidos durante a fase de análise do sistema (BOEHM, 1981, p. 46).

Além do software, um sistema muitas vezes é composto por equipamentos de hardware, cujo desenvolvimento também necessita de um levantamento de requisitos preliminar.

A Engenharia de Requisitos (ER) é uma disciplina da Engenharia de Software que procura sistematizar o processo de definição das necessidades de um sistema, abordando um ponto fundamental do desenvolvimento de software e hardware: a definição do que se produzir. Tem sido identificada como uma fase crucial por tratar de conhecimentos não apenas técnicos, mas também gerenciais, organizacionais, econômicos e sociais (CASTRO, 1995, p. 2), e estar intimamente associada à qualidade do produto (LEE et al., 1998, p. 10).

A Engenharia de Requisitos está relacionada aos objetivos do mundo real, devidamente transformados em funções e regras nos sistemas de software, a fim de tornar mais precisas as especificações do comportamento do software, bem como sua evolução ao longo do tempo (ZAVE, 1997, p. 315). Esta afirmação também pode ser aplicada ao hardware de um sistema. Ela corresponde ao processo de aquisição, refinamento e verificação das necessidades do cliente para um sistema de software, objetivando-se ter uma especificação completa e correta dos requisitos deste software. Esta mesma definição pode ser aplicada ao hardware.

Ian Sommerville (2004, p. 82) define a Engenharia de Requisitos como o processo de descobrir, analisar, documentar e verificar as funções e restrições de um sistema de software. 
Lamsweerde (2000, p. 5) define a Engenharia de Requisitos como sendo a identificação das restrições e dos objetivos a serem atingidos pelo futuro sistema, e a atribuição de responsabilidades pelos requisitos resultantes a agentes humanos, dispositivos e software.

Alan Davis (1993, p. 22) relaciona as atividades da Engenharia de Requisitos à produção de uma descrição completa do comportamento externo de um sistema a ser construído.

\subsection{Definição de Requisitos}

Antes do detalhamento das etapas da Engenharia de Requisitos é importante a definição de requisitos de um sistema.

Um requisito é uma característica de um sistema, ou a descrição de algo que um sistema deve realizar para atingir seus objetivos (PFLEEGER, 2004, p. 111).

A norma IEEE Std 610.12-1990 (IEEE, 1990, p. 62), define requisitos como:

- Uma condição ou capacidade necessária para o usuário resolver um problema ou atingir um objetivo; ou

- Uma condição ou capacidade que precise ser atendida ou estar presente em um sistema ou componente, para satisfazer um contrato, uma norma, uma especificação ou outro documento imposto formalmente; ou

- Uma representação documentada de uma condição ou capacidade, conforme definidas nos itens anteriores.

Esta definição abrange tanto a visão do usuário quanto a visão do desenvolvedor, no que diz respeito aos requisitos.

Requisitos são definidos durante os estágios iniciais do desenvolvimento de um sistema, como uma especificação do que deverá ser implementado. Eles descrevem um comportamento, uma propriedade ou um atributo do sistema. Podem também definir restrições ao processo de desenvolvimento do sistema (SOMMERVILLE; SAWYER, 1997b, p. 4). 
Para Jackson (1995, p. 169), requisitos são fenômenos ou propriedades do domínio da aplicação que devem ser executados. Normalmente são expressos em linguagem natural, diagrama informal ou outra notação apropriada ao entendimento do cliente e da equipe de desenvolvimento.

Tradicionalmente, os requisitos de software são classificados em requisitos funcionais, não funcionais e organizacionais (SOMMERVILLE, 2004, p. 83).

- Requisitos Funcionais: são as declarações das funções que o sistema deve oferecer, como o sistema se comporta com entradas particulares e como o sistema deve se comportar em situações específicas. O termo função é usado no sentido genérico da operação que pode ser realizada pelo sistema, seja por meio de comandos dos usuários, seja pela ocorrência de eventos internos ou externos ao sistema. Em alguns casos, os requisitos funcionais podem também explicitamente definir o que o sistema não deve fazer;

- Requisitos Não-Funcionais: são as restrições nas funções oferecidas pelo sistema. Incluem restrições de tempo, restrições no processo de desenvolvimento, padrões, e qualidades globais de um sistema, como manutenibilidade, usabilidade, desempenho, custos e várias outras;

- Requisitos Organizacionais: são derivados diretamente de procedimentos e políticas organizacionais e relacionados com os objetivos e metas da organização.

Existem várias formas de se entender um sistema qualquer. Similarmente, existem vários tipos de requisitos, que são aplicáveis ou não, dependendo da visão necessária naquele instante:

- Um requisito do usuário é algum comportamento ou característica que o usuário deseja do software ou o sistema como um todo (o que o usuário quer do sistema). São escritos pelo próprio usuário ou 
definidos por outro profissional que analisa, entende ou consulta 0 usuário;

- Um requisito do sistema é algum comportamento ou característica exigido do sistema como um todo, incluindo hardware e software. É o comportamento desejado do sistema. São normalmente definidos por engenheiros ou analistas de sistemas, refinando os requisitos dos usuários, e os traduzindo em termos de engenharia;

- Um requisito do software é algum comportamento ou característica que é exigido do software, normalmente definido por analistas de sistemas.

\subsection{O Processo da Engenharia de Requisitos}

O processo de Engenharia de Requisitos é um conjunto estruturado de atividades que devem ser seguidas para derivar, validar e manter um documento de requisitos de sistemas (KOTONYA; SOMMERVILLE, 1998, p. 9).

Segundo a "International Standards Organization" (ISO), o termo processo é definido como: "um grupo de atividades inter-relacionadas que se caracterizam por uma série de entradas específicas que agregam valor e fornecem uma série de saídas específicas para clientes externos e internos".

O processo de Engenharia de Requisitos pode ser definido como um processo com entradas e saídas, como mostra a Tabela 4. 
Tabela 4 - Entradas e saídas do processo de Engenharia de Requisitos

\begin{tabular}{|c|c|c|}
\hline Entrada ou Saída & Tipo & Descrição \\
\hline $\begin{array}{l}\text { Informações de } \\
\text { sistemas existentes }\end{array}$ & Entrada & $\begin{array}{l}\text { Informação sobre as funcionalidades dos sistemas } \\
\text { que serão substituídos, ou sistemas com os quais o } \\
\text { novo sistema irá interagir. }\end{array}$ \\
\hline $\begin{array}{l}\text { Necessidades dos } \\
\text { stakeholders }\end{array}$ & Entrada & $\begin{array}{l}\text { Descrição do que os stakeholders precisam do } \\
\text { sistema para apoiar seu trabalho. }\end{array}$ \\
\hline $\begin{array}{l}\text { Normas } \\
\text { organizacionais }\end{array}$ & Entrada & $\begin{array}{l}\text { Normas utilizadas na empresa que devem ser } \\
\text { consideradas no desenvolvimento do sistema, no } \\
\text { gerenciamento da qualidade, etc. }\end{array}$ \\
\hline Regulamentos & Entrada & $\begin{array}{l}\text { Regulamentos externos, tais como, regulamentos } \\
\text { para saúde e segurança, que devem ser aplicados } \\
\text { no sistema. }\end{array}$ \\
\hline $\begin{array}{l}\text { Informação } \\
\text { domínio }\end{array}$ & Entrada & $\begin{array}{l}\text { Informações gerais sobre o domínio da aplicação } \\
\text { do sistema. }\end{array}$ \\
\hline $\begin{array}{l}\text { Definição } \\
\text { requisitos }\end{array}$ & Saída & $\begin{array}{l}\text { Uma descrição dos requisitos do sistema, avaliada } \\
\text { e aprovada pelos stakeholders. }\end{array}$ \\
\hline $\begin{array}{l}\text { Especificação } \\
\text { sistema }\end{array}$ & Saída & $\begin{array}{l}\text { Especificação mais detalhada das funcionalidades } \\
\text { do sistema a ser desenvolvido. }\end{array}$ \\
\hline Modelos do sistema & Saída & $\begin{array}{l}\text { Conjunto de modelos, tais como, fluxo de dados, } \\
\text { modelo de objeto, modelo de processo, etc., que } \\
\text { descrevam o sistema sob diferentes perspectivas. }\end{array}$ \\
\hline
\end{tabular}

Fonte: KOTONYA; SOMMERVILLE, 1988, p. 105

Uma descrição completa do processo de ER deve incluir:

- Quais atividades são executadas;

- A estruturação e o cronograma dessas atividades;

- Quem são os responsáveis pelas atividades;

- Suas entradas e saídas.

$\mathrm{Na}$ literatura encontramos uma grande variedade de modelos, cujo objetivo é orientar a execução do processo de ER.

Um modelo é uma abstração de algo com o objetivo de entendê-lo antes de construílo. A construção de modelos facilita o desenvolvimento de software, separando pendências conceituais daqueles detalhes mais simples de implementação. Modelos 
podem ser usados para esclarecer pontos conceituais antes do desenvolvimento do software, servindo também para projetá-lo através de uma visão mais profunda. Por meio de uma base conceitual do sistema, um modelo pode ser elaborado para ser base de uma posterior implementação (BLAHA; RUMBAUGH, 2004, p. 15).

Baseados no modelo espiral do processo de desenvolvimento de software de Barry Boehm (1988, p. 64), Kotonya e Sommerville (1998, p. 57) propõem um modelo para o processo de ER, onde o início ocorre com a execução de atividades de levantamento de requisitos, seguidas pela análise e negociação desses requisitos, sua documentação e posterior validação (Figura 3).

Estas atividades se repetem ao longo dos ciclos de uma espiral, tantas vezes quantas sejam necessárias, até que se atinja um documento final de requisitos. Esse modelo espiral pode ser definido como sendo um conjunto de processos interativos, inter-relacionados e com re-alimentação de informações ("feedback'), que podem cobrir todo o ciclo de vida do projeto de software.

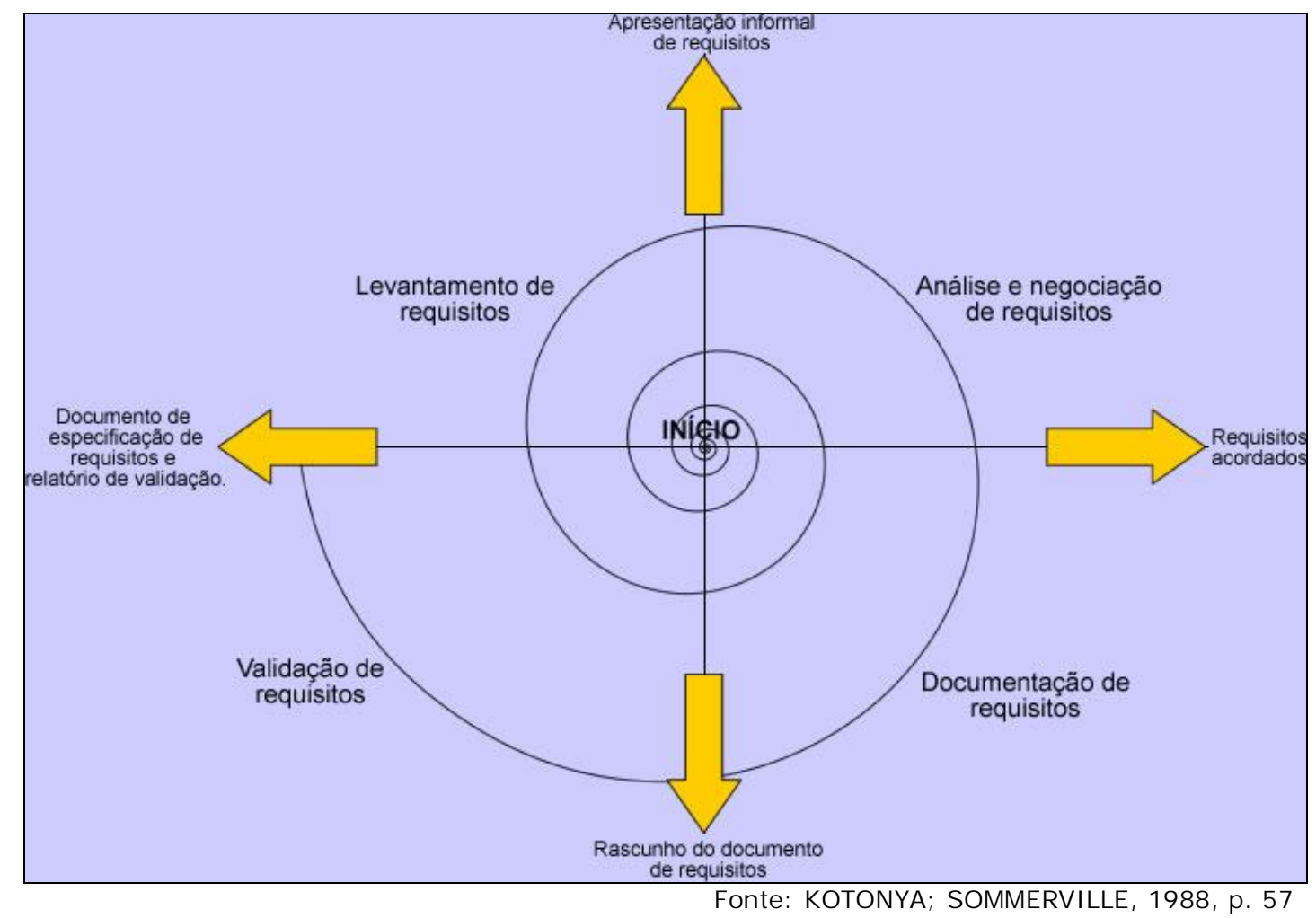

Figura 3 - Modelo espiral para o processo de Engenharia de Requisitos. 
Descobrir e definir os requisitos de um sistema é uma tarefa investigativa, da qual devem participar todos os envolvidos neste sistema. Sendo assim, antes de se prosseguir com a definição das atividades do processo de Engenharia de Requisitos, é importante identificarem-se os papéis de cada participante deste processo.

Existe uma grande diversidade de interesses das pessoas envolvidas em um sistema.

Denominam-se Stakeholders todos os indivíduos ou organizações envolvidos ativamente em um projeto de software, ou cujos interesses afetam este projeto: clientes, usuários, gerentes de projeto, analistas, desenvolvedores, financiadores, e outros (HOFMANN; LEHNER, 2001, p. 58).

Um tipo de Stakeholder que é muitas vezes esquecido é composto por aquelas pessoas que são afetadas pelo funcionamento do sistema, mesmo sem saber que ele existe ou está funcionando. Dizemos que essas pessoas estão "na sombra do sistema".

Antes de iniciar o processo de Engenharia de Requisitos de um sistema, é fundamental que se faça o levantamento de todos os Stakeholders e mapear, de alguma forma, seus interesses e interações com o mesmo.

As atividades que devem ser executadas em cada uma das fases do modelo Espiral são descritas nos itens a seguir.

\subsubsection{Levantamento}

Levantamento de requisitos é a atividade relacionada com a identificação dos requisitos do sistema, a partir de consulta aos representantes de cada grupo de usuários; da análise de documentos do domínio em questão; do conhecimento desse domínio; de pesquisas de mercado. A finalidade geral do processo de levantamento é identificar os fatos que compõem os requisitos do sistema, de forma a prover o mais correto entendimento do que dele é esperado. Um levantamento de requisitos consistente requer também uma criteriosa análise da organização, do domínio da aplicação e dos processos organizacionais. 
Existem quatro dimensões na atividade de levantamento de requisitos: o entendimento do domínio da aplicação, o entendimento do problema, o entendimento do negócio, e o entendimento das necessidades e das restrições dos Stakeholders.

O levantamento envolve todo um conjunto de ações, que ocorrem no universo de informações, visando capturar e registrar as informações que subsidiarão o entendimento do domínio do problema e a conseqüente especificação dos requisitos. A captura é um processo de descoberta no qual procura-se obter o máximo de informações para o conhecimento do objeto em questão. Requer uma habilidade em trabalhar com especialistas humanos e com o conhecimento tácito, que é trivial para quem conhece a informação, mas não é trivial para quem procura obtê-la, de forma que dificilmente é lembrado e, portanto, não é transmitido (GOGUEN; JIROTKA, 1994, p. 170).

Não é uma tarefa fácil obter esse conhecimento, pois os envolvidos têm experiências, conhecimentos, preconceitos e terminologias diferentes. Além disso, os geradores das informações podem não comentar algo que, para eles, parece óbvio, podendo gerar informações incompletas. Para isso, existem inúmeras técnicas propostas, dentre as quais podemos citar: análise de documentos, entrevistas, reuniões e observações.

- Análise de Documentos: É uma técnica usualmente aplicada na qual explora-se o conhecimento escrito encontrado no universo de informações. $\mathrm{Na}$ modelagem dos requisitos, segundo o modelo proposto, essa técnica é muito útil para a definição dos objetos que compõem o modelo. A análise dos documentos permite um contato com o vocabulário utilizado no domínio do problema e auxilia na construção do glossário de termos especializados, que tem por objetivo definir os objetos e igualar o conhecimento dos Stakeholders em relação ao sistema.

- Entrevista: É uma técnica de interação entre entrevistado (especialista do conhecimento) e entrevistador (engenheiro de requisitos) buscando revelar conceitos, objetos e a organização do domínio do problema, além de buscar soluções ou projeções de soluções que comporão o domínio da solução. As 
entrevistas mais usuais são as tutoriais, informais e estruturadas. Nas entrevistas tutoriais, o entrevistado fica no comando, praticamente lecionando sobre um determinado assunto. Nas entrevistas informais ou não estruturadas, o entrevistador age espontaneamente, perguntando ao entrevistado sem obedecer a nenhuma organização. Esse tipo de entrevista oferece flexibilidade ao entrevistador e, normalmente, é utilizado no início do processo de levantamento. Já as entrevistas estruturadas são preparadas pelo entrevistador, que define previamente o andamento do procedimento de aquisição de conhecimento. Um fator importante a ser considerado nas entrevistas é o registro das informações coletadas, que pode ser realizado através de anotações ou gravações de áudio ou vídeo. O material produzido deve ser organizado e serve como base para a preparação da próxima entrevista.

- Reunião: É uma técnica que prevê a participação coletiva dos envolvidos para discutir questões do domínio do problema. Esta prática permite uma interação mais natural entre os participantes e dispor de múltiplas visões sobre a questão abordada.

- Observação: É uma técnica na qual o engenheiro de requisitos procura ter uma posição passiva no domínio do problema, observando seus elementos e comportamentos. Esta estratégia visa obter um entendimento inicial sobre o contexto em estudo. As observações consistem em observar alguém no momento da realização de suas tarefas rotineiras no ambiente real. $O$ observador procura familiarizar-se com o domínio do problema e levantar as informações necessárias para o seu entendimento. A aquisição desse conhecimento pode ocorrer com interrupção ou não das atividades do observador. Na simples observação, ele pode acompanhar o raciocínio sem interromper o processo, enquanto que na análise por interrupção o observador pode suspender o processo a fim de esclarecer o raciocínio das atividades e operações realizadas. 


\subsubsection{Análise e Negociação}

A análise e a negociação de requisitos envolvem atividades que visam descobrir problemas com os requisitos de sistema e estabelecer um acordo de mudanças que satisfaça a todos os afetados. O processo de análise e negociação é caro e demorado porque requer pessoas qualificadas e experientes para dedicar tempo à leitura cuidadosa de documentos e identificar conflitos e inconsistências. Na maioria das vezes, as atividades de análise e de negociação de requisitos são executadas de forma paralela ou intercaladas em conjunto com atividades de levantamento de requisitos.

Durante o processo de análise, os requisitos são examinados a fim de se detectar omissões, redundâncias, inconsistências e/ou requisitos irreais. A preocupação está em identificar os requisitos que são realmente necessários ao desenvolvimento do sistema e ao atendimento das necessidades dos clientes.

A negociação envolve a discussão dos conflitos encontrados entre requisitos e a busca por uma solução de comum acordo que debele o conflito e atenda aos anseios de todas as partes envolvidas. Os requisitos finais devem exprimir um compromisso que comas necessidades da organização em geral, os requisitos específicos de diferentes partes interessadas, e com as restrições de projeto, implementação, prazo e orçamento para o desenvolvimento do sistema. Para tanto, os modelos de negociação geralmente identificam as principais necessidades dos usuários, priorizando-as a fim de assegurar que os requisitos mais críticos a elas relacionados sejam atendidos o quanto antes. Isso envolve a interação entre gerente de projeto e clientes para o planejamento e organização das versões intermediárias do sistema final.

A seguir são apresentadas as técnicas mais comumente utilizadas no processo de análise e negociação.

- Listas de Verificação: Correspondem a listas de questões que o analista pode fazer uso para avaliar cada requisito. Também chamadas de Checklists, são úteis já que provêem uma referência sobre o que procurar e reduzem as chances de que requisitos importantes deixem de ser checados. Ao final da checagem, pode-se disponibilizar uma lista de inconsistências encontradas, 
que podem ser solucionadas por meio de negociação ou, caso necessário, novo levantamento de requisitos.

- Matrizes de Interação: São utilizadas para denotar a interação entre requisitos e facilitar o processo de análise de possíveis conflitos entre estes. A forma mais simples de construção dessas matrizes é usar uma tabela e rotular suas linhas e colunas com identificadores de requisitos. Valores numéricos indicam a relação entre cada um dos requisitos mapeados, evidenciando conflitos ou sobreposições. Requisitos com altos valores correlacionados devem ser cuidadosamente analisados para avaliar o impacto que essas relações, e eventuais mudanças nas mesmas, possam ter no desenvolvimento do sistema.

- Prototipação: Os protótipos criados na etapa de levantamento podem ser aperfeiçoados na etapa de análise e negociação, possibilitando uma análise mais rica dos requisitos do sistema. Além disso, protótipos contribuem para um maior envolvimento entre as partes interessadas durante as atividades de levantamento, análise e negociação de requisitos.

- Reunião: É uma das técnicas mais utilizadas para a resolução de conflitos entre requisitos. Nela pode-se contar com a participação coletiva dos envolvidos, que podem ter uma interação mais natural e dispor de múltiplas visões sobre a questão abordada. Numa reunião de negociação podem ser seguidos os seguintes passos:

1. Explicação sobre a natureza dos problemas de requisitos;

2. Discussão entre as partes de como resolver os problemas, observando as prioridades estabelecidas;

3. Resolução dos conflitos pela tomada de ações corretivas. 


\subsubsection{Documentação}

Nesta fase, os requisitos acordados são anotados num documento que reúne, num nível apropriado de detalhe, o escopo de requisitos que servirá como base para o processo de desenvolvimento do sistema. O documento de requisitos serve como um contrato entre usuários e desenvolvedores, e deve ser formatado e estruturado de forma clara para todos os envolvidos.

Pfleeger (2004, p. 139) sugere esta documentação em dois tipos de documento: um para que o cliente possa ler, chamado de definição de requisitos, e outro com os requisitos para ser utilizado como base para o desenvolvimento do sistema, chamado de especificação de requisitos.

\subsubsection{Documento de Definição de Requisitos}

A utilização de uma linguagem natural facilita a compreensão do processo de requisitos por todas as pessoas envolvidas com o sistema, o que leva as organizações, muitas vezes, a definirem seus próprios padrões de documentação de requisitos. Entretanto, deve-se tomar cuidado para que as definições registradas desta forma sejam claras e não ambíguas.

Davis (1993, p. 181) alerta que a linguagem natural, apesar da vantagem de ser entendida por todos os participantes do processo de requisitos, apresenta um alto grau de ambigüidade, o que favorece o aparecimento de inconsistências. Segundo ele, isso acontece quando nos comunicamos verbalmente, pois parte dos elementos utilizados em nossa expressão oral na linguagem natural - a expressão corporal - é perdida. Dessa forma, conseguimos registrar apenas parte das informações que expressamos.

\subsubsection{Documento de Especificação de Requisitos}

Depois de fechado, o documento de definição de requisitos deve ser reestruturado em uma linguagem técnica adequada ao desenvolvimento do sistema, originando o documento de especificação de requisitos (PFLEEGER, 2004, p.114). 
Uma especificação de requisitos de software é um documento contendo a descrição completa do que o software fará, independente dos detalhes de implementação (DORFMAN; THAYER, 1990, p. 325).

A norma IEEE Std 830-1998 é uma recomendação prática para a elaboração de especificações de requisitos de software, aceita internacionalmente. Ela descreve o conteúdo e as qualidades de uma boa especificação de requisitos de software, e apresenta alguns exemplos (IEEE, 1998b, p. 1).

De acordo com a norma IEEE Std 830-1998 (IEEE, 1998b, p. 4), o documento de especificação de requisitos deve possuir declarações não-ambíguas, ser completo, verificável, consistente, modificável, rastreável e utilizável durante todas as fases do ciclo de vida do projeto a ser desenvolvido. Alguns autores conceituam este documento como sendo o meio utilizado para descrever as restrições quanto às características do produto e ao processo de desenvolvimento, a interface com outras aplicações, a informação sobre o domínio da aplicação e informações de suporte ao conhecimento do problema.

Nesse sentido, a especificação de requisitos deve promover a redução do tempo total e esforço dedicado ao processo de criação do sistema, evitando o re-trabalho quanto à especificação, codificação e testes do sistema.

Existem muitas maneiras diferentes de estruturar um documento de especificação de requisitos. Este pode ser definido como um único artefato, ou ser formado pela associação de diferentes artefatos que provêem visões de requisitos específicas para cada faceta do desenvolvimento, uma abordagem comum nos modernos documentos de requisitos de software (LEFFINGWELL, 1999, p. 262).

\subsubsection{Validação}

A validação de requisitos é definida como o processo que certifica que o modelo de requisitos gerado esteja consistente com as necessidades e intenções de clientes e usuários. Nesta etapa deve-se verificar se o documento de requisitos atende as necessidades dos clientes e usuários finais.

É importante que se faça uma distinção entre análise de requisitos e validação de requisitos. Apesar de ambas as atividades terem muito em comum - ambas 
envolvem analisar os requisitos, julgar se são uma descrição apropriada das necessidades dos Stakeholders e verificar os requisitos com relação à presença de problemas - existem diferenças importantes que justificam o tratamento de ambas em separado.

Validação não é uma tarefa fácil e pode requerer várias sessões de trabalho até que todos encontrem não somente pontos de concordância a respeito dos requisitos, mas principalmente visualizem as implicações futuras de suas decisões. Nesse sentido, a participação de especialistas de domínio contribui sobremaneira para a orientação de clientes, usuários e desenvolvedores na resolução de possíveis impasses.

$\mathrm{Na}$ Engenharia de Requisitos existe uma variedade de técnicas que podem ser aplicadas para apoiar o processo de validação. Algumas dessas técnicas são descritas nos itens a seguir.

- Revisões: Dentre as técnicas mais utilizadas para validação de requisitos, as revisões envolvem um grupo de pessoas lendo e analisando a documentação de requisitos à procura de possíveis problemas. A revisão de requisitos constitui-se de uma reunião formal na qual é apresentado cada um dos requisitos para crítica e identificação de inconsistências pela equipe. Cada problema encontrado deve ser discutido até que se defina uma solução. De acordo com o número de requisitos de um sistema, estas revisões podem representar muitas horas de trabalho. A escolha das pessoas que irão compor a equipe de revisão também deve ser cuidadosa. $O$ ideal é que a equipe contenha pelo menos um representante de cada uma das áreas envolvidas no sistema (desde o usuário final até o programador).

- Prototipação: Se na etapa de levantamento de requisitos foi desenvolvido um protótipo, pode-se utilizá-lo posteriormente para a validação desses requisitos. Por outro lado, se um protótipo não estiver disponível, construí-lo apenas para a validação dos requisitos não será economicamente atraente. Os protótipos para validação devem ser mais completos e conter requisitos suficientes para garantir que facilidades projetadas para o sistema estão de acordo com o uso prático esperado por seus usuários. Protótipos feitos 
durante o levantamento normalmente não apresentam todas as funcionalidades incluídas durante o processo de análise dos requisitos. Normalmente, é necessário complementar o desenvolvimento do protótipo para a etapa de validação.

- Testes de Requisitos: Uma das qualidades de um requisito bem elaborado é que ele possa ser testado. Uma boa maneira de identificar problemas nos requisitos tais como, falta de completitude ou ambigüidade, é tentar propor casos de teste para um requisito. A construção de cenários auxilia na definição do contexto no qual o teste deve ser aplicado. Kotonya e Sommerville (1998, p. 106) afirmam que, se a definição de casos de teste para um dado requisito for difícil, isso indica que pode existir algum tipo de problema com a definição do requisito. Pode estar faltando alguma informação no requisito, ou sua descrição pode estar incorreta.

\subsection{Técnicas e Métodos da Engenharia de Requisitos}

O objetivo do processo de ER é definir um documento de especificação de requisitos para o sistema a ser desenvolvido, com o maior grau de qualidade nas informações. Esta não é uma tarefa fácil, uma vez que muitos erros e omissões de requisitos são identificados, mesmo após terem sua validação. Por estas razões, diversas técnicas e métodos que orientam, estruturam e organizam as atividades deste processo, têm sido cada vez mais adotados.

Nesse contexto, a palavra "técnicas" envolve tanto procedimentos técnicos quanto gerenciais que ajudam na avaliação e melhoria do processo de desenvolvimento de software (IEEE, 1990, p. 74).

Métodos geralmente são compostos por uma ou mais técnicas individuais, e definem detalhadamente os procedimentos para a construção de um produto, que na Engenharia de Requisitos trata-se do documento de especificação de requisitos.

Para NUSEIBEH e EASTERBROOK (2000, p. 37), os métodos exercem um papel importante no processo de Engenharia de Requisitos, fornecendo uma sistemática de como executar um conjunto de atividades, combinando e integrando diferentes 
técnicas e notações. Eles orientam o processo de engenharia de requisitos para o desenvolvimento de uma notação apropriada ou técnica de modelamento, nos diferentes estágios deste processo.

Algumas técnicas e métodos se aplicam somente a uma fase do processo de engenharia de requisitos, enquanto que outros são recomendados para diversas delas. A escolha das técnicas e métodos a serem utilizados em cada fase, deve ser feita de acordo com o tipo de sistema a ser desenvolvido e com o perfil das pessoas envolvidas (desenvolvedores, clientes, usuários, etc.).

Nos itens a seguir, são detalhados alguns dos principais métodos e técnicas que podem ser aplicados em um processo de Engenharia de Requisitos.

\subsubsection{Joint Application Design (JAD)}

A Joint Application Design, mais conhecida como JAD, é uma metodologia de reunião que enfatiza a participação coletiva no levantamento de requisitos. É uma prática bem conhecida de negociação de requisitos, que promove a cooperação, entendimento e formação de equipes de trabalho entre os envolvidos no universo de informações.

Esta técnica baseia-se em sessões estruturadas e disciplinadas, onde os envolvidos reúnem-se para desenvolver o sistema de software. Em linhas gerais, nessas sessões faz-se uso da técnica brainstorming, onde é solicitado a todos os participantes que contribuam com o maior número de idéias possíveis. Uma reunião de JAD deve possuir uma agenda detalhada, recursos visuais para auxilio na exposição de idéias, e um mediador para conduzir as discussões e administrar os conflitos durante a sessão.

Uma JAD oferece um ambiente apropriado para os desenvolvedores e usuários trabalharem em equipe, com o objetivo de compartilhar informações e idéias sobre os domínios do problema e da solução. Este processo auxilia a comunicação entre os envolvidos, que se empenham em identificar necessidades, refinar requisitos, tomar decisões conjuntas, explorar possíveis soluções e selecionar alternativas apropriadas. 
Outra técnica semelhante a JAD é a Participatory Design (PD), cuja abordagem se concentra mais fortemente no envolvimento dos usuários, em relação ao JAD, por facilitar o processo de aprendizado entre desenvolvedores e usuários através de experiências conjuntas em situações de trabalho simuladas. Em linhas gerais, os usuários são introduzidos no ambiente dos desenvolvedores, conhecendo possibilidades técnicas e, da mesma maneira, os desenvolvedores colaboram com os usuários em suas tarefas. Ocorre um aprendizado que contribui no processo de definição dos requisitos.

JAD representa um movimento em direção a práticas mais colaborativas procurando viabilizar objetivos, enquanto que PD representa um movimento em direção a práticas mais técnicas, procurando viabilizar os objetivos. Ambas as metodologias são bem conhecidas por acentuar um alto grau de envolvimento dos usuários como imperioso para o desenvolvimento de um bom projeto de software. Como resultado, os desenvolvedores aumentam seus conhecimentos sobre o domínio da aplicação e os usuários tornam-se mais envolvidos no processo de desenvolvimento.

\subsubsection{Cenários}

O desenvolvimento de um novo sistema implica na transformação das tarefas e práticas atuais dos usuários e da organização. Conhecer a situação atual e antecipar o impacto que um novo sistema deve ter é fundamental para o seu sucesso. Uma das formas de se fazer um levantamento destas informações, é através da construção de cenários.

Segundo Leite (2000, p. 41), um cenário é uma descrição parcial do comportamento da aplicação, que ocorre em um dado momento, em uma situação específica. Os métodos baseados em cenários consistem de uma coleção de narrativas de situações no domínio, que favorecem o levantamento de informações, a identificação de problemas e a antecipação das soluções.

A elaboração dos cenários deve ser feita através de informações obtidas em reuniões realizadas com os usuários do futuro sistema, onde estes possam explicar suas atividades e solicitar os dados que necessitam. Muitas das informações e requisitos fornecidos pelos usuários nesta etapa podem parecer desnecessários. 
Assim como ocorre em outras técnicas, o usuário raramente sabe exatamente o que quer, pois não consegue ter uma visão clara do sistema a ser desenvolvido e, muitas vezes, solicita itens dispensáveis. Mesmo assim, é importante que todas as informações coletadas sejam consideradas na construção dos cenários, cuja análise poderá facilitar a definição dos requisitos a serem definidos.

A estrutura definida por Leite (2000, p. 44) para uma descrição de um cenário é composta pelos seguintes itens:

- Título: identifica o cenário;

- Objetivo: estabelece a finalidade de um cenário. O cenário deve descrever o modo em que este objetivo deve ser alcançado;

- Contexto: descreve o estado inicial de um cenário, suas précondições, o local (físico) e tempo;

- Recursos: identificam os objetos passivos com os quais lidam os atores;

- Atores: pessoas ou estruturas organizacionais que têm um papel no cenário;

- Episódios: cada episódio representa uma ação realizada por um ator onde participam outros atores utilizando recursos disponíveis. Um episódio também pode se referir a outro cenário. Episódios podem conter restrições e exceções. Uma restrição é qualquer imposição que restrinja um episódio de um cenário;

- Exceções: tratamentos para uma situação excepcional ou de erro.

\subsubsection{Casos de Uso}

Mesmo com a aplicação das técnicas de levantamento descritas anteriormente, a identificação de todos os requisitos do sistema não é uma tarefa trivial. A elaboração de casos de uso a partir destas informações é uma metodologia que auxilia a definição dos requisitos funcionais de um sistema. 
Segundo Jacobson (1992, p. 127), um caso de uso é um documento narrativo que descreve uma seqüência de transações realizadas por um ator. Um caso de uso é uma técnica de modelagem usada para descrever o que um novo sistema deve fazer, sem se preocupar em como ele vai fazer. Segundo o autor, cada caso de uso define um requisito funcional do sistema.

Os casos de uso definem um conjunto orientado de interações entre atores e o sistema em questão. Os atores são agentes externos ao sistema, que interagem com ele (GRADY; RUMBAUGH; JACOBSON, 1998, p. 222).

Os casos de uso descrevem seqüências de ações que o sistema desempenha para produzir um resultado esperado pelo usuário. Cada seqüência representa a interação de entidades externas e o sistema. Estas entidades são chamadas de atores e que podem ser usuários ou outros sistemas. Um ator representa na verdade uma função de usuários. Pode-se dizer que os componentes de um modelo de casos de uso são:

- Ator - é um papel que tipicamente estimula ou solicita ações do sistema e recebe reações. Cada ator pode participar de vários casos de uso;

- Casos de uso - é um documento narrativo que descreve a seqüência de eventos feitos por um ator no uso do sistema;

- Sistema - é o sistema a ser modelado.

Na UML (Unified Modeling Language), o modelo de casos de uso consiste de diagramas de casos de uso que mostram os atores, os casos de uso e seus relacionamentos. Os elementos gráficos que representam atores, casos de uso e sistema são mostrados na Figura 4. 


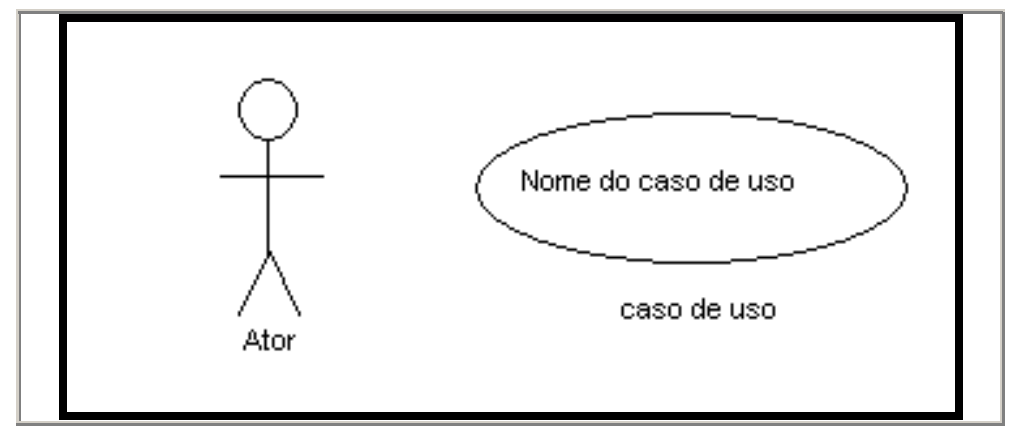

Figura 4 - Elementos de um caso de uso

Os casos de uso podem ser aplicados no levantamento e análise de requisitos, para estabelecer os cenários operacionais do sistema. Além de representar os requisitos, os casos de uso também descrevem uma solução em alto nível, o que facilita o entendimento e a comunicação das diversas pessoas envolvidas.

\subsubsection{Pontos de Vista (Viewpoints)}

As técnicas de levantamento de requisitos baseadas em pontos de vista (viewpoints) se baseiam no fato de que os requisitos de um sistema devem ser obtidos através de várias perspectivas deste sistema, ou seja, de diferentes pontos de vista.

Um ponto de vista é um encapsulamento de uma informação parcial sobre os requisitos de um sistema. Informações de diferentes pontos de vista devem ser integradas para gerar-se a especificação final do sistema (SOMMERVILLE; SAWYER, 1997a, p. 103).

Os principais argumentos a favor desta técnica são (SOMMERVILLE; SAWYER, 1997a, p. 104):

- A utilização de um sistema é heterogênea. Através de pontos de vista, pode-se organizar os requisitos de diferentes classes de usuários e stakeholders;

- Diferentes tipos de informações são necessários para especificar um sistema, incluindo o domínio da aplicação, ambiente de desenvolvimento e de execução do sistema. Os pontos de vista podem ser utilizados para coletar e classificar estas informações; 
- Pontos de vista podem ser utilizados como um meio para estruturar o processo de levantamento de requisitos, e expor os conflitos entre os diferentes requisitos;

- Pontos de vista podem ser utilizados para encapsular diferentes modelos de um sistema, o que fornece mais informações para a especificação do sistema.

O levantamento de requisitos através de pontos de vista é proposto em diversos métodos, dentre os quais pode-se citar: Vord (Viewpoint-Oriented Requirements Definition), Preview (Process and Requirements Engineering Viewpoints), SADT (Structured Analysis and Design Technique), VOSE (Viewpoint-Oriented System Engineering), e CORE (Controlled Requirements Expression). Cada um destes adota uma definição particular dos pontos de vista. Exemplo: No método CORE os pontos de vista representam processos, enquanto que no SADT são fontes geradoras de dados.

Dos métodos baseados em pontos de vista, são detalhados neste documento apenas o Vord e o Preview.

\subsubsection{Vord}

O método chamado Vord (Viewpoint-Oriented Requirements Definition) foi projetado por Gerald Kotonya e lan Sommerville (1996, p. 11), para o levantamento de requisitos orientado a pontos de vista.

No Vord, inicialmente os pontos de vista relevantes são identificados e separados em subgrupos. Depois, os requisitos dos pontos de vista são coletados, classificados por importância, documentados, analisados e especificados.

Uma das atividades propostas neste método é o cruzamento dos requisitos dos diversos pontos de vista, para que sejam detectados conflitos, inconsistências ou omissões nestes requisitos. A forma de documentação dos requisitos no Vord é livre, ou seja, a linguagem utilizada pode ser: formal, informal ou estruturada.

O Anexo A contém uma tradução resumida do Vord. 


\subsubsection{Preview}

O método Preview - Process and Requirements Engineering Viewpoints foi proposto por lan Sommerville e Pete Sawyer (1997a, p. 114) como uma evolução do método Vord.

Este método também é voltado à elicitação e documentação de requisitos e propõe que a análise seja baseada nos objetivos organizacionais, limitando assim o escopo dos pontos de vista. Este limite facilita as etapas de descoberta e análise dos requisitos.

O Anexo B contém uma tradução resumida do Preview.

\subsubsection{Volere}

Desenvolvido em 1995, por Suzanne Robertson e James Robertson (1999, p. 277), - Volere é um método baseado na utilização de casos de uso, e que abrange todas as etapas definidas na Engenharia de Requisitos. Através de um modelo padrão de especificação de requisitos, define passo a passo, como os requisitos do sistema devem ser levantados, analisados, validados e documentados, para que se obtenha no final, um documento de especificação de requisitos do sistema a ser desenvolvido. Devido à sua utilização por milhares de desenvolvedores de software ao redor do mundo, muitas sugestões e observações são recebidas, analisadas e incorporadas pelos autores a cada ano.

O Anexo $\mathrm{C}$ contém uma tradução resumida do Volere.

No próximo capítulo é detalhado o levantamento e definição de requisitos para o sistema proposto, utilizando como base algumas das técnicas e métodos apresentados neste capítulo. 


\section{LEVANTAMENTO DE REQUISITOS PARA O SISTEMA PROPOSTO}

Este capítulo descreve todos os procedimentos realizados para o levantamento dos requisitos para o Sistema de Transponders.

Das diversas técnicas e métodos definidos na Engenharia de Requisitos, o método Volere detalha, de forma clara e abrangente, todas as etapas do processo de levantamento e definição dos requisitos de um sistema. Além disso, este método permite que se acrescente ou suprima etapas de sua estrutura, de acordo com a necessidade do sistema, o que é fundamental em projetos onde tempo e custo são fatores limitantes na definição dos requisitos.

Este trabalho aplica o método Volere, cuja estrutura, adaptada às necessidades deste projeto, é composta pelas seguintes etapas:

- Objetivos do Sistema;

- Stakeholders do Sistema;

- Usuários do Sistema;

- Pontos de Vista;

- Restrições do Sistema;

- Nomenclaturas e Definições;

- Escopo do Negócio;

- Escopo do Sistema;

- Requisitos dos Pontos de Vista;

- Análise e Negociação dos Requisitos;

- Definição dos Requisitos;

- Validação dos Requisitos. 


\subsection{Objetivos do Sistema}

No mercado brasileiro de transporte rodoviário de cargas, o monitoramento das viagens executadas pelos veículos tem se tornado cada vez mais importante. Atualmente, os produtos e sistemas disponíveis para este tipo de operação, têm um custo muito elevado para a grande maioria das empresas.

Diante desta lacuna do mercado, o desenvolvimento de um sistema que monitore e forneça dados sobre as viagens executadas por uma frota, a um baixo custo de implantação e manutenção, parece ser perfeitamente viável. Este desenvolvimento, no entanto, deve partir de uma especificação de requisitos bem elaborada.

O objetivo principal deste projeto é elaborar esta especificação de requisitos para o Sistema de Transponders, aplicando as técnicas e métodos definidos na Engenharia de Requisitos.

Devido às limitações de tempo e investimento, é importante que, durante as diversas etapas, as técnicas e atividades propostas nos métodos utilizados, sejam adequadas à estas restrições.

\subsection{Stakeholders do Sistema}

Nos próximos itens serão listados os clientes, consumidores e outros stakeholders importantes no levantamento de requisitos para o Sistema de Transponders.

\subsubsection{Cliente e Consumidores}

Os clientes e consumidores deste sistema deverão ser as empresas de logística e de gerenciamento de riscos, que necessitam monitorar viagens de diversas empresas, e possuem toda a estrutura para o gerenciamento das informações. Além disso, estas empresas definem o valor do seguro a ser pago em cada viagem de transporte de carga, e podem associar descontos neste valor para veículos que possuam o Sistema de Transponders (isto já é feito para veículos que possuem sistemas de rastreamento). 
Duas importantes empresas de gerenciamento logístico e de riscos do mercado brasileiro de transporte de cargas firmaram um acordo para testes "piloto" deste projeto. Destas empresas, que passarão a ser tratadas neste trabalho por empresas de monitoramento, as pessoas envolvidas direta ou indiretamente com o sistema serão:

- Gerente de Logística;

- Analista de Riscos;

- Operador do Sistema de Gerenciamento de Riscos;

- Operador do Sistema de Gerenciamento Logístico;

- Analista de Sistemas.

\subsubsection{Outros Stakeholders}

A definição dos requisitos de um sistema não pode ser feita apenas considerando-se o cliente e os usuários finais. Um grupo muito importante a ser considerado, são os profissionais da empresa que desenvolverá o produto:

- Gerente do Projeto;

- Gerente Comercial;

- Analistas de Sistemas;

- Engenheiros Eletrônicos;

- Engenheiros de Produção;

- Eletricistas Automotivos;

- Técnicos de Suporte;

- Técnicos de Manutenção;

- Homologadores do Sistema. 


\subsection{Usuários do Sistema}

O Sistema de Transponders deverá ser ter como usuários finais as seguintes entidades:

- Transportadoras de pequeno porte;

- Transportadoras de grande porte, que transportem mercadorias de baixo valor agregado;

- Motoristas autônomos.

Um outro grupo importante de usuários deste sistema serão os setores de logística dos embarcadores. O nome embarcador é dado para a empresa que contratou o transporte da carga, geralmente o fabricante ou distribuidor da mercadoria embarcada no veículo.

Alguns fabricantes e distribuidores possuem frota de veículos própria para a distribuição de suas mercadorias, atuando como uma Transportadora na visão deste sistema.

Destas entidades, as pessoas envolvidas direta ou indiretamente com o sistema serão:

\section{Transportadora:}

- Analista de Sistemas;

- Analista de Logística;

- Gerente de Logística;

- Operador do Sistema;

- Eletricista Automotivo;

- Motorista do Veículo (funcionário da empresa). 


\section{Embarcador:}

- Gerente de Logística;

- Operador do Sistema;

- Motorista de Veículo (funcionário da empresa).

\section{Autônomos:}

- Motorista Autônomo de Veículo. 


\subsection{Pontos de Vista}

Um ponto de vista é a perspectiva que um determinado stakeholder tem sobre o projeto a ser desenvolvido ou sobre o produto a ser gerado por ele.

O próximo passo definido no método Volere é o levantamento e definição das restrições do sistema. Antes disso, no entanto, será elaborada uma estrutura hierárquica das classes de pontos de vista, da qual serão selecionados os pontos de vista relevantes ao sistema.

A inclusão desta etapa no método Volere é justificada pelo fato de que, segundo (ALEXANDER, 2005, p. 37), a análise dos pontos de vista ajuda na descoberta de diversos grupos de requisitos, e pode indicar possíveis conflitos, ajudando na criação de uma especificação mais estável e completa.

Sendo assim, o processo de levantamento e análise de requisitos do sistema proposto será feito com base nos pontos de vista.

\subsubsection{Classes de Ponto de Vista}

Esta estrutura permite que sejam identificados os diversos pontos de vista relevantes ao sistema, os quais podem ser separados em dois conjuntos de pontos de vista:

- os associados aos stakeholders do sistema;

- os associados às regras e restrições que o sistema deverá seguir.

Segundo Sommerville e Sawyer (1997a, p. 104), o primeiro conjunto facilita a identificação de todos os stakeholders importantes para o levantamento de requisitos. O segundo conjunto não pode ser associado a nenhum tipo de stakeholder, mas inclui informações coletadas de muitas fontes diferentes (pessoas, documentos, outros sistemas, etc.).

Portanto, pretende-se com a utilização dos pontos de vista, complementar a etapa de levantamento de requisitos do método Volere. 
De acordo com os métodos Vord e Preview, os pontos de vista (diretos ou indiretos) podem ser representados em um conjunto de classes, cada uma delas podendo ter subclasses, e assim sucessivamente.

As Figuras 5, 6, 7 e 8 representam a estrutura das classes de pontos de vista relevantes para o Sistema de Transponders, e suas respectivas subclasses. Cada um destes pontos de vista serão descritos posteriormente:

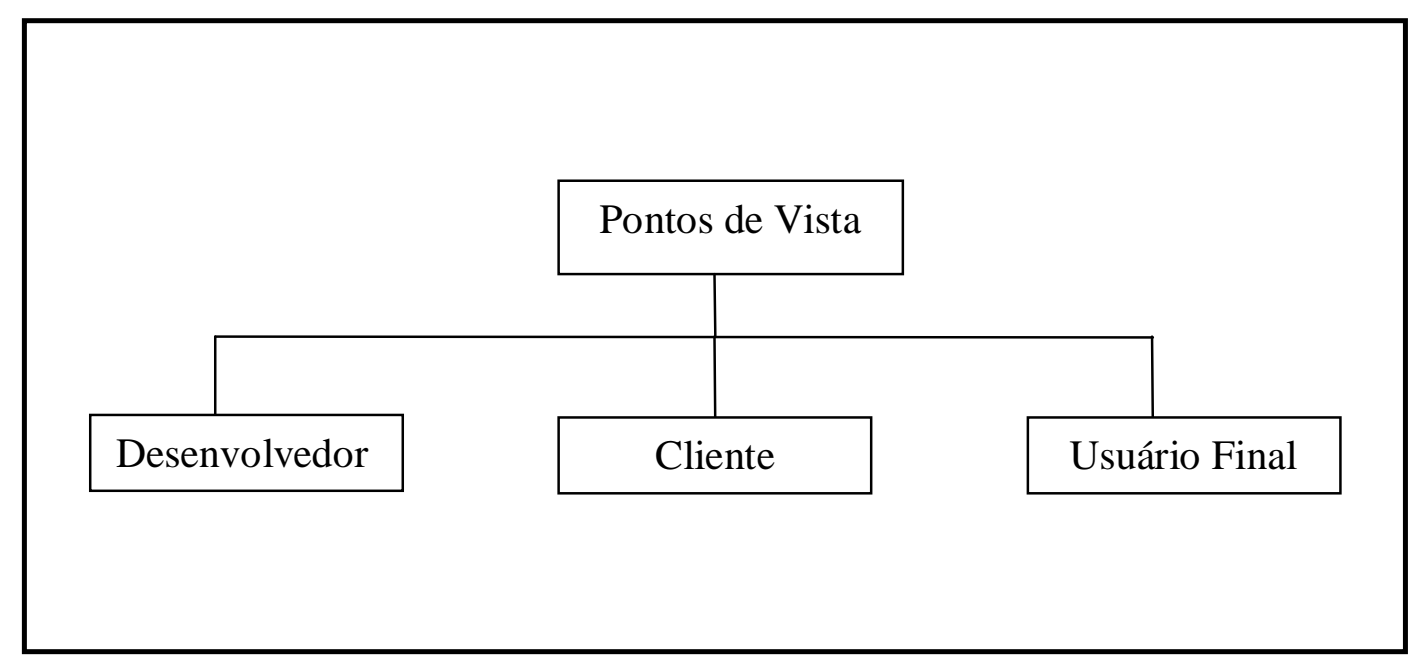

Figura 5 - Estrutura de classes dos pontos de vista 
Subdivisões das classes:

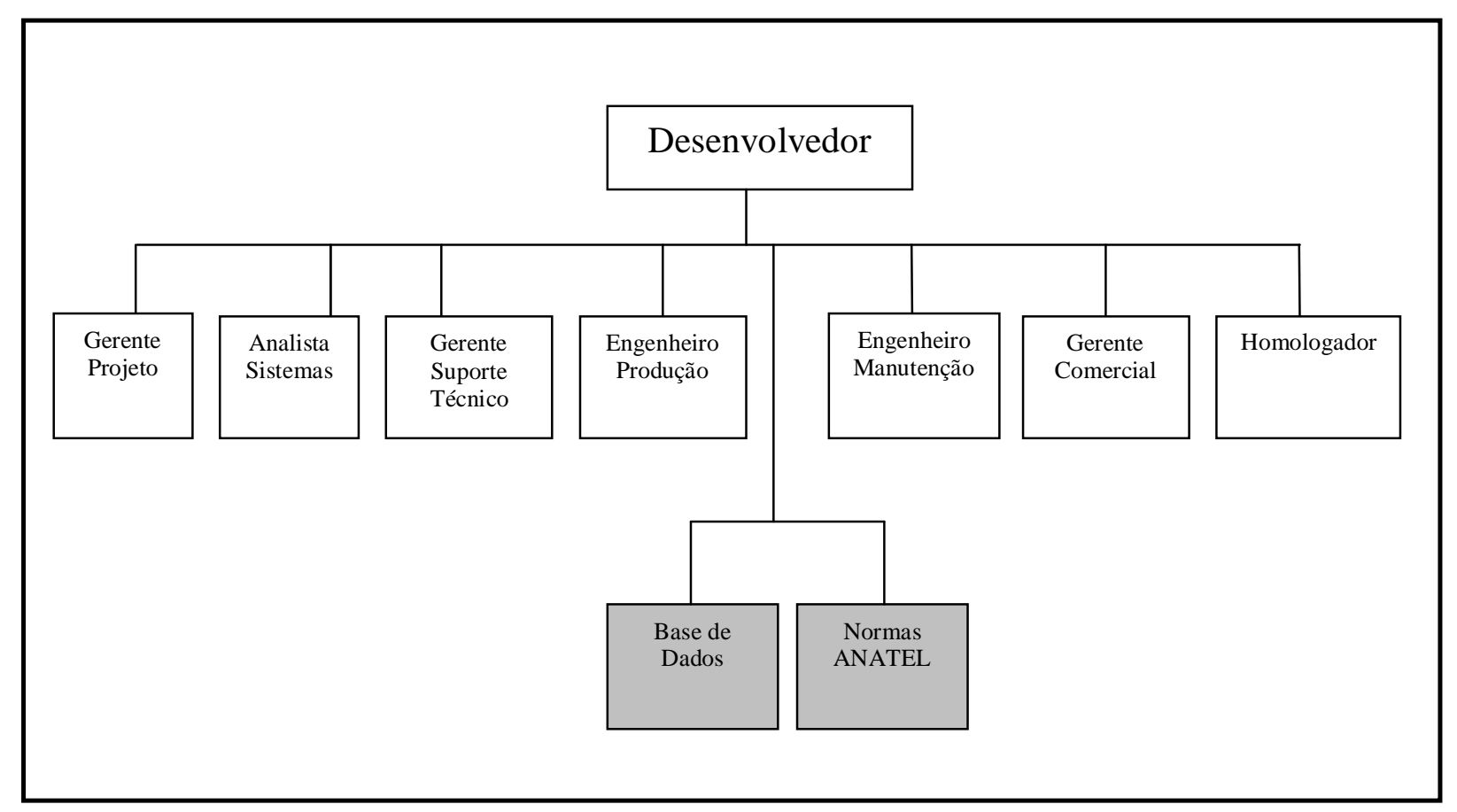

Figura 6 - Estrutura da subdivisão da classe Desenvolvedor

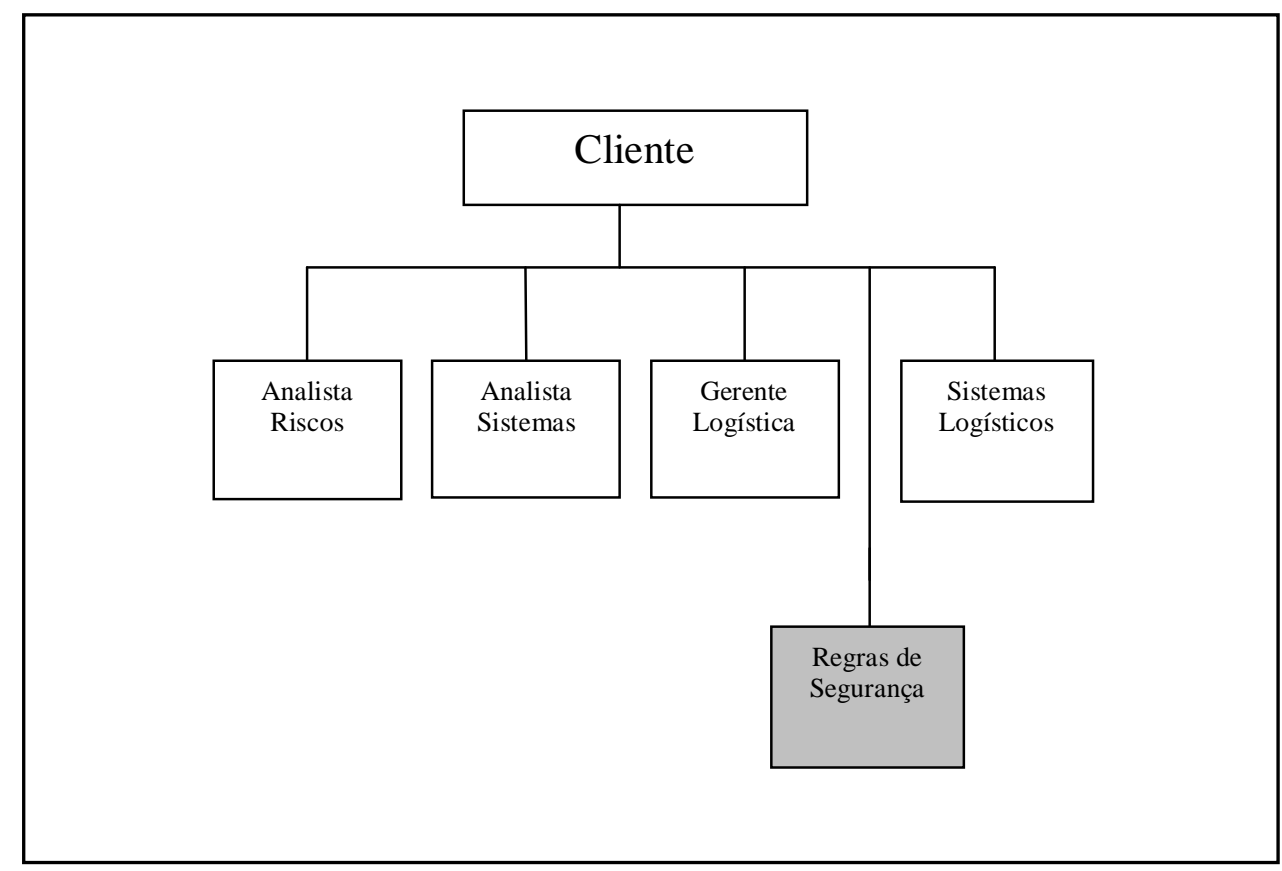

Figura 7 - Estrutura da subdivisão da classe Cliente 


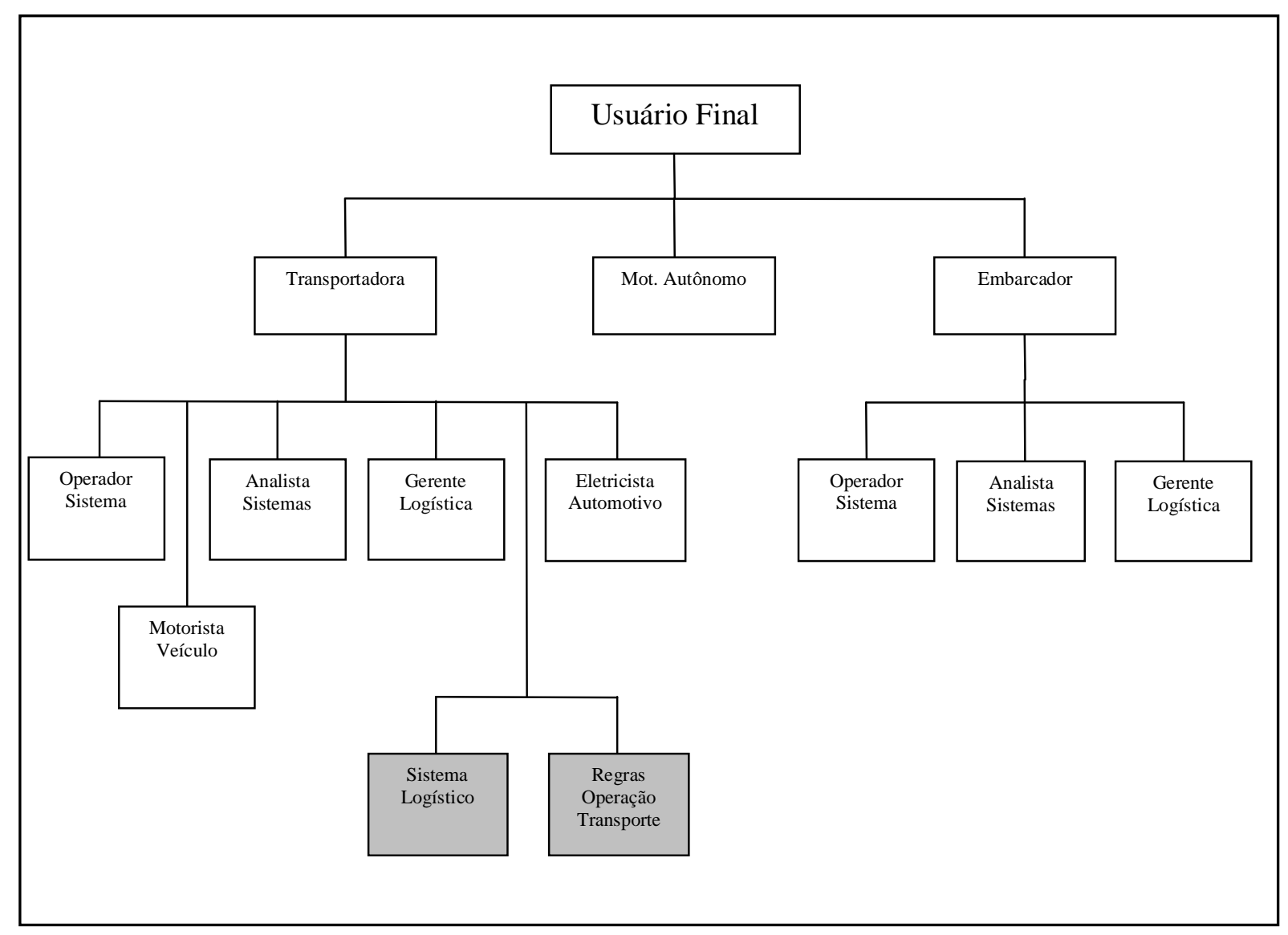

Figura 8 - Estrutura da subdivisão da classe Usuário Final

Legenda: 


\subsubsection{Pontos de Vista Selecionados}

A identificação de muitos pontos de vista para um sistema, implica em um grande número de informações e prioridades a serem gerenciadas. Dependendo da empresa e do tipo de sistema a ser desenvolvido, isso por ser um grande problema.

Com o objetivo de reduzir o tempo gasto na etapa de levantamento e definição de requisitos do Sistema de Transponders, fez-se uma análise da estrutura de classes de pontos de vista apresentada anteriormente, para exclusão de alguns pontos de vista irrelevantes para esta proposta ou que possuíssem foco e objetivos semelhantes aos demais.

Os pontos de vista a seguir foram considerados importantes e serão utilizados no levantamento de requisitos:

\section{Classe Desenvolvedor:}

- Gerente do Projeto;

- Gerente Comercial;

- Gerente de Suporte Técnico;

- Analista de Sistemas;

- Engenheiro de Produção;

- Engenheiro de Manutenção;

- Homologador.

\section{Classe Cliente:}

- Gerente de Logística;

- Analista de Riscos;

- Analista de Sistemas. 


\section{Classe Usuário Final (Transportadora ou Embarcador):}

- Analista de Sistemas;

- Gerente de Logística;

- Eletricista Automotivo;

- Motorista do Veículo.

Alguns dos pontos de vista apresentados na estrutura de classes não serão utilizados nas demais etapas deste trabalho, por não serem considerados relevantes ao sistema, ou por possuírem foco e objetivos semelhantes aos demais.

\subsection{Restrições do Sistema}

Antes de levantarmos os requisitos de um produto, é importante que algumas restrições e premissas sejam definidas. Diferentemente da grande maioria dos requisitos, estas devem, obrigatoriamente, ser atendidas pelo produto.

Devido ao segmento de mercado que se deseja atingir com este sistema, as definições prévias e restrições a seguir deverão ser obrigatoriamente atendidas. Cada uma destas definições ou restrições tem uma razão, e um ou mais critérios a serem seguidos:

a) Deverá haver um equipamento de pequeno porte, a ser instalado nos veículos que serão monitorados pelo sistema.

Razão: Para que os veículos possam ser monitorados, eles precisam ter algum tipo de equipamento que troque informações com as demais partes do sistema.

Critério: O equipamento deverá ser facilmente instalado no painel do veículo a ser monitorado. Suas dimensões não poderão exceder 12 centímetros de comprimento por 6 centímetros de largura e 2 centímetros de altura. 
b) O equipamento a ser instalado no veículo deverá ser de fácil instalação.

Razão: Não deverão existir oficinas de instalação do produto. Os usuários finais deverão ser capazes de instalar o equipamento somente com o auxílio de um manual.

Critério: Os fios para a instalação do equipamento deverão ser conectados à caixa de fusíveis do veículo, cujo acesso é fácil em todos os tipos de veículo.

c) A tecnologia utilizada para a troca de informações entre o equipamento instalado no veículo e as demais partes do sistema deverá ser economicamente viável.

Razão: O alto custo da comunicação de dados pode inviabilizar um sistema.

Critério: De acordo com o tipo de comunicação definido, deverão existir equipamentos fixos, instalados ao longo das principais rodovias brasileiras, capazes de receber executar esta troca de informações com os veículos.

d) Se algum dos equipamentos do sistema utilizar comunicação por Radiofreqüência (RF) ou por Telefonia Celular, estes deverão ser homologados e certificados pela Anatel (Agência Nacional de Telecomunicações).

Razão: Para a comercialização de equipamentos que utilizem comunicação por RF ou Telefonia Celular, é necessário que estes possuam uma etiqueta adesiva de certificação da Anatel. A Anatel é uma empresa governamental que define regras de utilização e de comportamento para equipamentos de telecomunicações no Brasil.

Critério: Os projetos de hardware e de software dos equipamentos que utilizarem RF ou Telefonia Celular deverão seguir as regras e procedimentos regulamentados e padronizados pela Anatel. Os primeiros protótipos deverão ser enviados para homologação e certificação na Anatel. 
e) Deverá existir um servidor central (computador) instalado no CPD da empresa que desenvolverá o sistema, e conectado à rede internet 24 horas por dia. Este servidor receberá as informações dos pontos instalados ao logo das rodovias, e deverá disponibilizá-las também via internet aos clientes e usuários do sistema.

Razão: A operação de monitoramento deve ser feita 24 horas por dia, e a troca de informações através da internet é mais barata.

Critério: O servidor central deverá ter grande capacidade de memória e processamento.

f) O hardware dos equipamentos instalados nos veículos e nas rodovias deverá ter pouca memória para gravação de programas e dados.

Razão: Os componentes de memória devem ser reduzidos para diminuição do custo de produção do equipamento.

Critério: Deverá ser previsto o mínimo de memória possível para a gravação dos programas e dos dados necessários.

g) O software dos equipamentos a serem instalados nos veículos e nas rodovias deverá ser desenvolvido na linguagem $\mathrm{C}$.

Razão: A empresa que desenvolverá o sistema já possui ferramentas e profissionais especializados, além desta linguagem ser indicada para equipamentos a serem embarcados.

Critério: Deverá ser utilizada a linguagem C para o desenvolvimento deste software.

h) O software do servidor central deverá ser desenvolvido na linguagem Java.

Razão: A empresa que desenvolverá o sistema já possui ferramentas e profissionais especializados, além desta linguagem ser indicada para sistemas que utilizam a internet. 
Critério: Deverá ser utilizada a linguagem Java para o desenvolvimento deste software.

\subsection{Nomenclaturas e Definições}

A estrutura geral do Sistema de Transponders será formada por: equipamentos instalados nos veículos, equipamentos instalados ao logo das principais rodovias do país e um servidor central. Cada uma destas partes receberá os seguintes nomes:

Transponder - equipamento instalado nos veículos.

Base - equipamento instalado em pontos fixos das rodovias.

Servidor Central - servidor (computador) central do sistema.

Os seguintes nomes serão utilizados nesta proposta:

Leds - abreviação para "Light Emmiting Diodes", que significa "Diodos Emissores de Luz". São indicadores colocados nos painéis de alguns equipamentos, e que podem ser de diversas cores (vermelho, verde, amarelo, etc.).

Logs - informações gravadas em memória pelos equipamentos durante sua execução, cuja análise permite diagnosticar todas as operações realizadas.

\subsection{Escopo do Negócio}

Para a obtenção de dados sobre as operações realizadas pelas empresas de transporte rodoviário de cargas no Brasil, foram realizadas reuniões com representantes de empresas de monitoramento. Destas reuniões participaram representantes dos departamentos de: sistemas, gerenciamento de riscos, gerenciamento logístico e marketing, o que resultou em uma coleta de material ampla e detalhada. 
Nas primeiras reuniões procurou-se relacionar em detalhes cada uma das operações realizadas atualmente pelas transportadoras, embarcadores e motoristas autônomos. Muitos requisitos para o novo sistema já começaram a ser observados nesta etapa.

\subsubsection{Situação Atual}

Atualmente, o monitoramento das viagens de transporte de cargas realizadas por veículos que não possuem algum tipo de sistema de rastreamento é precário. Esta é a realidade da grande maioria que compõe o mercado de transporte rodoviário de cargas brasileiro.

Informações sobre a situação de uma viagem, cujo veículo não possui sistema de rastreamento, são normalmente obtidas através de contatos telefônicos feitos pelos motoristas.

As empresas deste setor necessitam de soluções mais acessíveis do que os sistemas de rastreamento, que viabilizem 0 acompanhamento das viagens executadas por suas frotas.

\subsubsection{Diagrama de Contexto}

A Figura 9 mostra o diagrama de contexto de um sistema de monitoramento de viagem por cartão, utilizado atualmente por algumas empresas de transporte rodoviário de cargas: 


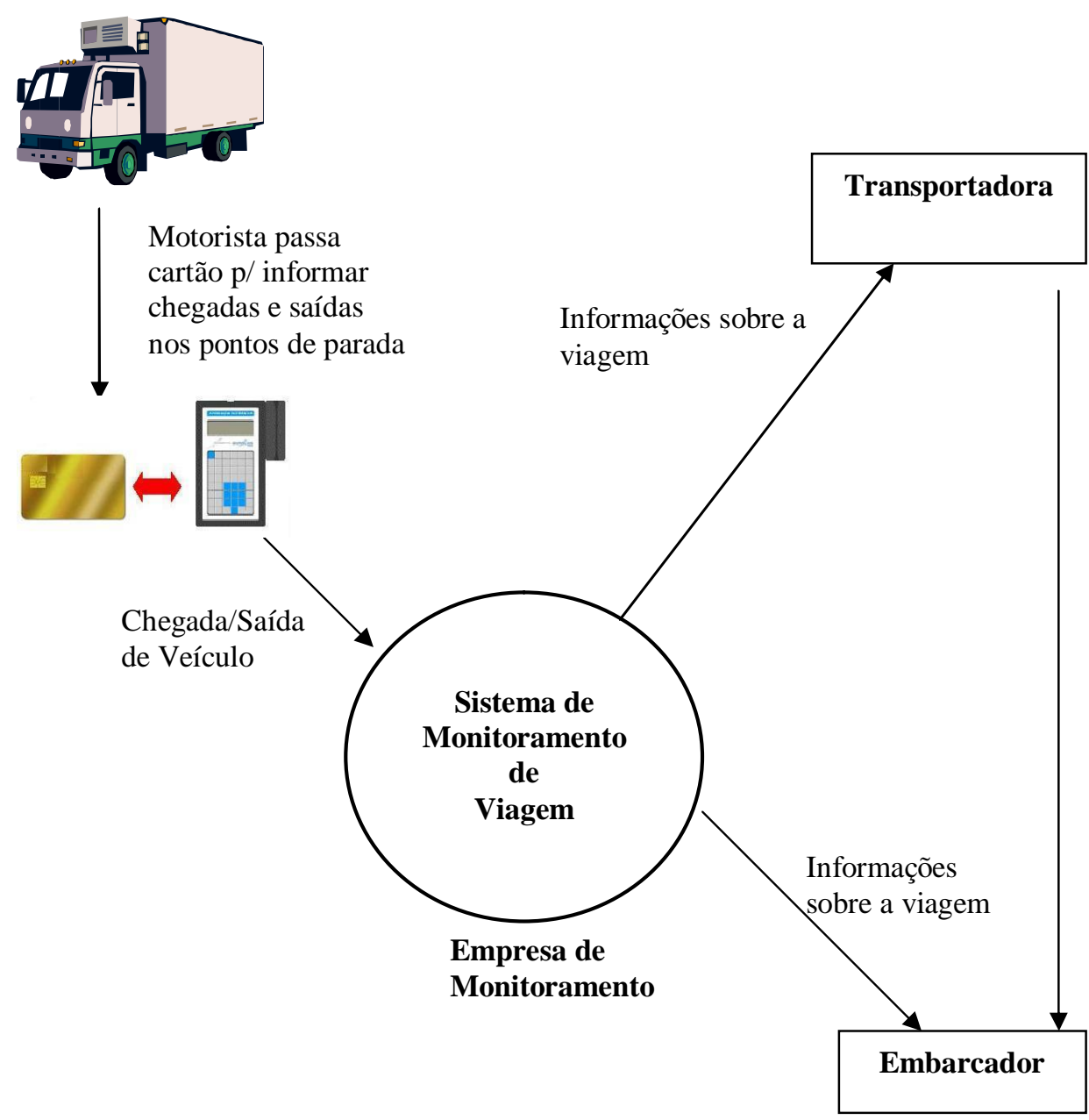

Figura 9 - Diagrama de contexto - monitoramento por cartão 


\subsubsection{Casos de Uso do Negócio}

Conforme mencionado anteriormente, o Sistema de Transponders terá como meta atender o segmento de transporte rodoviário de cargas, cujos veículos não possuem nenhum tipo de equipamento para rastreamento ou monitoramento à distância. Este item descreve os casos de negócio relacionados ao monitoramento de viagens deste tipo de veículo, cujas operações atuais são controladas através da passagem do cartão magnético do motorista em terminais dedicados.

$\mathrm{Na}$ Tabela 5 a seguir estão descritos todos os eventos que atualmente ocorrem em uma viagem "monitorada por cartão magnético" no transporte rodoviário de cargas:

Tabela 5 - Casos de uso do negócio

\begin{tabular}{ll}
\hline \multicolumn{1}{c}{ Nome do Evento } & \multicolumn{1}{c}{ Entrada (E) / Saída (S) } \\
\hline Veículo inicia uma viagem & Saída do veículo da origem (E) \\
\hline $\begin{array}{l}\text { Veículo chega a um ponto de } \\
\text { parada }\end{array}$ & $\begin{array}{l}\text { Chegada de veículo em um ponto de } \\
\text { parada (E) }\end{array}$ \\
\hline $\begin{array}{l}\text { Veículo sai de um ponto de } \\
\text { parada }\end{array}$ & $\begin{array}{l}\text { Saída de veículo de um ponto de } \\
\text { parada (E) }\end{array}$ \\
\hline Veículo finaliza uma viagem & Chegada do veículo no destino (E) \\
\hline Problemas em um terminal & $\begin{array}{l}\text { Relatório de Terminal com Problemas } \\
\text { (S) }\end{array}$ \\
\hline
\end{tabular}

A descrição dos passos a serem realizados em cada um dos eventos acima será feita através de casos de uso. Para facilitar, o nome de cada caso de uso será o nome do evento a ele associado:

1) Nome: Veículo inicia uma viagem.

Atores: Motorista, terminal, sistema da empresa de monitoramento. 
Descrição: Este caso de uso começa quando um veículo sai do pátio de uma empresa (transportadora ou embarcador), iniciando uma viagem.

O motorista passa seu cartão magnético em um terminal da portaria do pátio, informando sua saída.

O terminal envia uma mensagem para o sistema da empresa de monitoramento, informando uma saída de veículo associado ao cartão magnético lido. Nestes casos, as viagens são associadas ao número do cartão magnético do motorista.

Ao receber esta mensagem, o sistema considera que a viagem teve início.

2) Nome: Chegada de veículo em um ponto de parada.

Atores: Motorista, Terminal, Sistema da Empresa de Monitoramento.

Descrição: Este caso de uso começa quando um veículo faz uma parada em um ponto previsto de sua viagem.

O motorista passa seu cartão magnético em um terminal instalado neste ponto de parada, informando o motivo da mesma.

O terminal envia uma mensagem para o sistema da empresa de monitoramento, informando uma parada de veículo associado ao cartão magnético lido.

Ao receber esta mensagem, o sistema registra a parada do veículo no ponto associado àquele terminal.

3) Nome: Saída de veículo de um ponto de parada.

Atores: Motorista, Terminal, Sistema da Empresa de Monitoramento.

Descrição: Este caso de uso começa quando um veículo vai sair de um ponto de parada.

O motorista passa seu cartão magnético no terminal, informando que está saindo do local. 
O terminal envia uma mensagem para o sistema da empresa de monitoramento, informando uma saída de veículo associado ao cartão magnético lido.

Ao receber esta mensagem, o sistema registra que o veículo saiu do ponto associado àquele terminal e está prosseguindo sua viagem.

4) Nome: Veículo termina uma viagem.

Atores: Motorista, Terminal, Sistema da Empresa de Monitoramento.

Descrição: Este caso de uso começa quando um veículo chega ao ponto final de sua viagem, que normalmente é o pátio de uma transportadora ou embarcador.

O motorista passa seu cartão magnético em um terminal instalado neste ponto, informando o final da viagem.

O terminal envia uma mensagem para o sistema da empresa de monitoramento, indicando o final da viagem associada ao cartão magnético lido.

Ao receber esta mensagem, o sistema registra que a viagem foi finalizada.

5) Nome: Problemas em um terminal.

Atores: Terminal, Suporte Técnico e Sistema da Empresa de Monitoramento.

Descrição: Este caso de uso começa quando o sistema da empresa de monitoramento detectar que um terminal não tem enviado mensagens indicando seu estado operacional (de tempos em tempos o terminal deve enviar ao sistema uma mensagem indicando seu estado de operação).

O sistema da empresa de monitoramento gera um relatório de "Terminal com Problema".

O responsável pelo sistema no suporte técnico da empresa de monitoramento inicia os procedimentos de verificação e, se necessário, de troca do terminal com suspeita de problemas. 


\subsection{Escopo do Sistema}

Uma vez conhecidos os detalhes das operações atuais para o monitoramento de uma viagem através de cartões magnéticos, foi iniciada a etapa de definição das interfaces, dos eventos e casos de uso do sistema a ser desenvolvido - Sistema de Transponders.

\subsubsection{Interfaces do Sistema}

As interfaces do Sistema de Transponders com os demais sistemas estão representadas no diagrama da Figura 10:

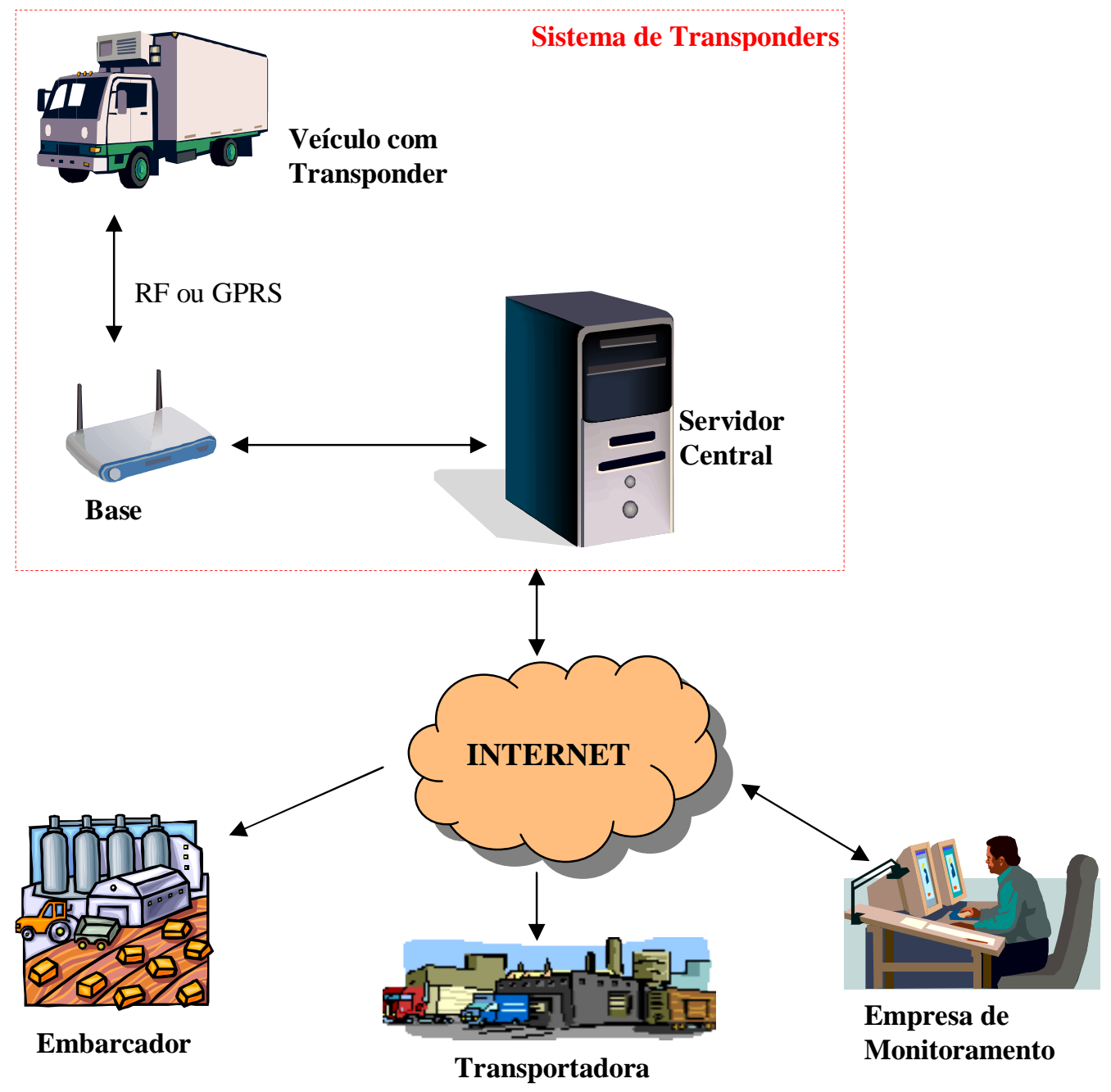

Figura 10 - Interfaces do sistema 


\subsubsection{Casos de Uso do Sistema}

Na Tabela 6 a seguir estão os eventos identificados até o momento, e que deverão ser recebidos (entradas) ou gerados (saídas) pelo Sistema de Transponders:

Tabela 6 - Casos de uso do sistema

\begin{tabular}{ll}
\hline \multicolumn{1}{c}{ Nome do Evento } & \multicolumn{1}{c}{ Entrada (E) / Saída (S) } \\
\hline Cadastro de Transponder & Novo Transponder (E) \\
\hline Cadastro de Base & Nova Base (E) \\
\hline Problema em uma Base & Relatório de Base Suspeita (S) \\
\hline Problema em um Transponder & $\begin{array}{l}\text { Relatório de Transponder Suspeito } \\
(\text { S) }\end{array}$ \\
\hline Veículo inicia uma viagem & Saída do veículo da origem (E) \\
\hline Veículo passa por uma Base & $\begin{array}{l}\text { Passagem de veículo por uma Base } \\
\text { (E) }\end{array}$ \\
\hline Veículo termina uma viagem & Chegada do veículo no destino (E) \\
\hline
\end{tabular}

A descrição dos passos a serem realizados em cada um dos eventos acima será feita através de casos de uso. Para facilitar o entendimento desses casos de uso, serão adotadas as seguintes definições:

- O nome de cada caso de uso será o nome do evento a ele associado;

- O nome Clientes indicará empresas de monitoramento;

- O nome Usuários indicará empresas transportadoras ou embarcadores.

1) Nome: Cadastro de Transponder.

Atores: Servidor Central, Operador de Sistemas do Usuário, Sistema do Usuário. 
Descrição: Este caso de uso começa quando o operador de sistemas de um usuário for cadastrar um novo Transponder instalado.

Ele registra no sistema da sua empresa os dados do Transponder e do veículo no qual foi feita a instalação.

O sistema do usuário envia estes dados para o Servidor Central do Sistema de Transponders, para a atualização da base de dados.

2) Nome: Cadastro de Base.

Atores: Servidor Central, Técnico de Instalação, Gerente de Suporte Técnico (ambos da empresa que desenvolverá o produto).

Descrição: Este caso de uso começa quando um técnico telefona para o gerente de suporte técnico, informando a instalação de uma nova Base.

O gerente registra no banco de dados do Servidor Central os dados da Base e do ponto onde ela foi instalada, tornando-a operacional.

O Servidor Central envia estes dados para os diversos sistemas de clientes autorizados (transportadoras, embarcadores, gerenciadores de riscos).

3) Nome: Problema em uma Base.

Atores: Servidor Central, Gerente de Suporte Técnico.

Descrição: Este caso de uso começa quando o Servidor Central detectar que uma Base não está se comunicando, ou não tem enviando eventos de Transponders.

O Servidor Central gera um relatório de "Base Suspeita".

O Gerente de Suporte Técnico inicia os procedimentos de verificação e, se necessário, de manutenção da Base com suspeita de problemas.

4) Nome: Problema em um Transponder.

Atores: Servidor Central, Gerente de Suporte Técnico. 
Descrição: Este caso de uso começa quando o Servidor Central detectar que um Transponder não tem se comunicado com as Bases.

O Servidor Central gera um relatório de "Transponder Suspeito".

O Gerente de Suporte Técnico inicia os procedimentos de verificação e, se necessário, de manutenção do Transponder com suspeita de problemas.

5) Nome: Veículo inicia uma viagem.

Atores: Transponder, Base, Servidor Central, Sistemas dos Clientes e dos Usuários.

Descrição: Este caso de uso começa quando um veículo equipado com o Transponder sai de um pátio que possua uma Base instalada, iniciando uma viagem.

A Base envia uma mensagem para o Servidor Central, indicando o horário em que o Transponder saiu do pátio.

O Servidor Central envia uma mensagem de aviso desta saída aos diversos sistemas de clientes e usuários associados a este Transponder.

6) Nome: Passagem de veículo por uma Base.

Atores: Transponder, Base, Servidor Central, Sistemas dos Clientes e Usuários.

Descrição: Este caso de uso começa quando um Transponder passa por uma Base e comunica-se com ela.

O Transponder envia sua identificação e os dados obtidos do veículo para a Base.

A Base envia estes dados para o Servidor Central.

O Servidor Central envia uma mensagem de aviso desta passagem aos diversos sistemas de clientes e usuários associados a este Transponder. 
7) Nome: Veículo termina uma viagem.

Atores: Transponder, Base, Servidor Central, Sistemas dos Clientes e Usuários.

Descrição: Este caso de uso começa quando um veículo equipado com o Transponder chega a um pátio que possua uma Base instalada, terminando uma viagem.

A Base envia uma mensagem para o Servidor Central, indicando o horário em que o Transponder chegou ao pátio.

O Servidor Central envia uma mensagem de aviso desta chegada aos diversos sistemas de clientes e usuários associados a este Transponder.

O conjunto de casos de uso definido nesta etapa será utilizado como ponto de partida para a identificação dos requisitos funcionais e não funcionais para o Sistema de Transponders.

\subsection{Requisitos dos Pontos de Vista}

Após a identificação das interfaces e a definição dos casos de uso do sistema, o método Volere sugere que sejam levantados e relacionados os requisitos funcionais e os não funcionais de todos os stakeholders. Devido à heterogeneidade destes stakeholders, optou-se por fazer este levantamento, baseado em pontos de vista, segundo as recomendações dos métodos Vord e Preview. Esta decisão foi baseada no fato de que as reuniões de levantamento de requisitos seriam mais produtivas se os participantes tivessem um foco e objetivos em comum.

Sendo assim, antes do início das reuniões com os stakeholders, foram definidos e separados os objetivos e o foco de cada um dos pontos de vista.

Posteriormente, iniciaram-se os ciclos de reuniões com cada um dos grupos de pontos de vista. Em cada uma destas reuniões eram apresentados o foco e os objetivos organizacionais definidos para aquele ponto de vista, o que direcionou e facilitou o processo de obtenção dos requisitos das diversas fontes presentes. 
Para o registro dos requisitos obtidos nestas reuniões, definiu-se um formulário cujo formato resulta de uma combinação dos padrões sugeridos nos métodos Volere, Vord e Preview.

A Figura 11 mostra o formulário de registro dos requisitos dos pontos de vista, adaptado do Volere:

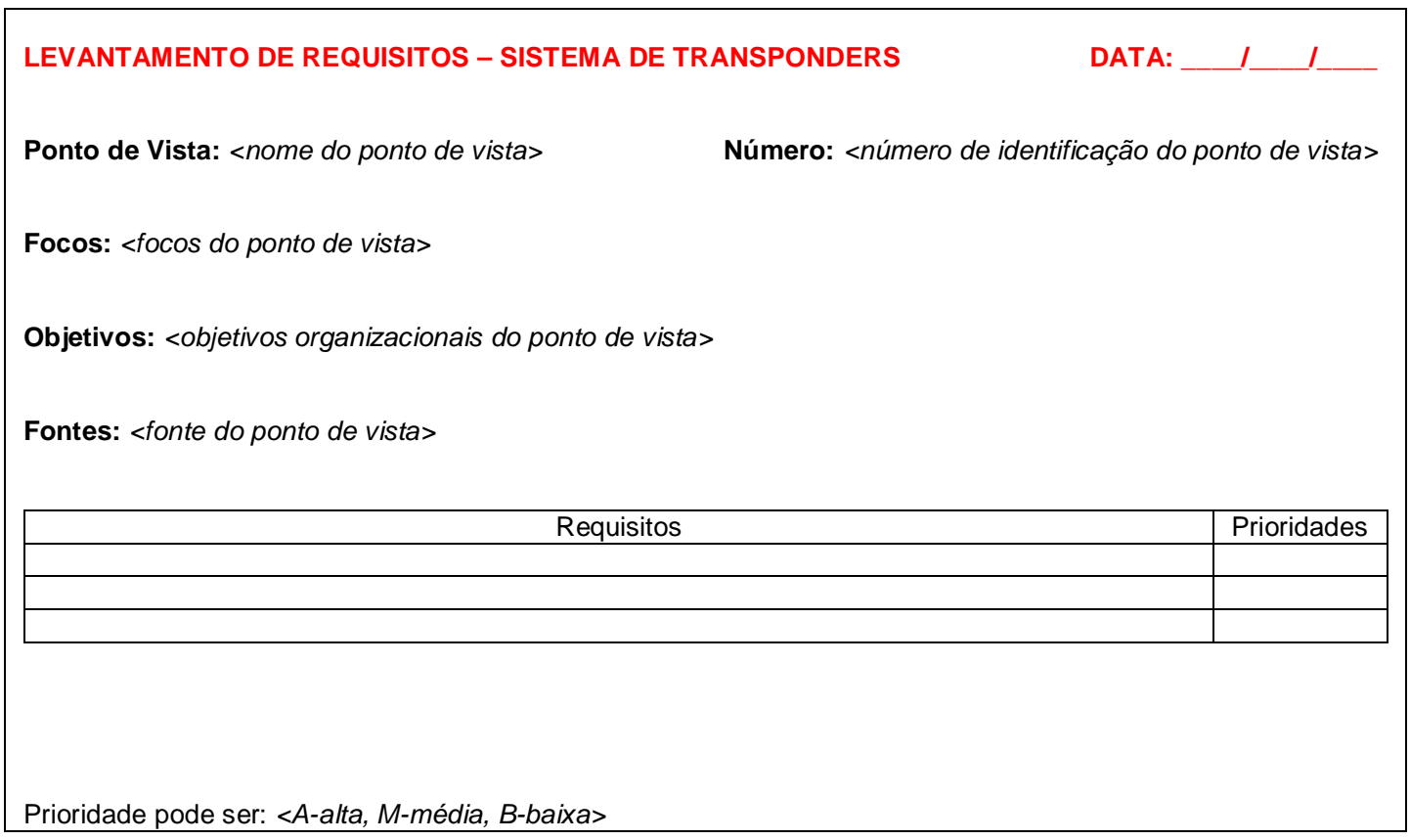

Figura 11 - Formulário de registro de requisitos do sistema

O número de identificação do ponto de vista foi inserido no formulário acima para facilitar o rastreamento dos requisitos quando houver a necessidade.

A etapa de reuniões para levantamento de requisitos estendeu-se por aproximadamente 6 semanas. Em cada reunião eram reunidos os representantes de uma determinada classe de ponto de vista, que após algumas discussões preenchiam o formulário acima com os requisitos de sua categoria.

Este item apresenta a seguir, apenas a relação parcial dos requisitos solicitados por cada um dos pontos de vista deste sistema. 


\title{
4.9.1 Requisitos da Classe Desenvolvedor
}

\begin{abstract}
Ponto de Vista: Gerente do Projeto
Número: 001

Foco: Estabelecer e organizar a equipe de desenvolvimento, convocar e liderar reuniões, planejar o projeto, controlar metas e linhas críticas do projeto, elaborar os manuais de operação do sistema.

Objetivos: Coordenar e finalizar o desenvolvimento do Sistema de Transponders segundo as metas estabelecidas.

Fontes: Normas, definições e metas de negócio da empresa que desenvolverá o sistema.
\end{abstract}

\begin{tabular}{|l|c|}
\hline \multicolumn{1}{|c|}{ Requisitos } & Prioridades \\
\hline $\begin{array}{l}\text { Disponibilidade de todos os recursos alocados para este } \\
\text { projeto. }\end{array}$ & $\mathrm{M}$ \\
\hline $\begin{array}{l}\text { Facilidade de comunicação com a equipe de desenvolvimento } \\
\text { e com os usuários. }\end{array}$ & $\mathrm{A}$ \\
\hline $\begin{array}{l}\text { O software desenvolvido tem que ser de ótima qualidade. } \\
\text { ser registradas em ata. }\end{array}$ & $\mathrm{M}$ \\
\hline $\begin{array}{l}\text { O desenvolvimento do software deve ser iniciado somente } \\
\text { após a conclusão e a aprovação das especificações de } \\
\text { implementação dos programas. }\end{array}$ & $\mathrm{A}$ \\
\hline $\begin{array}{l}\text { A especificação de requisitos do sistema deve atender ao } \\
\text { maior número possível de stakeholders. }\end{array}$ & $\mathrm{A}$ \\
\hline $\begin{array}{l}\text { As especificações de implementação dos programas devem } \\
\text { ser iniciadas somente após a conclusão e a aprovação das } \\
\text { especificaçes funcional e de interfaces do sistema. }\end{array}$ & $\mathrm{A}$ \\
\hline
\end{tabular}


continuação

\begin{tabular}{|l|c|}
\hline \multicolumn{1}{|c|}{ Requisitos } & Prioridades \\
\hline $\begin{array}{l}\text { O desenvolvimento do software deve seguir os padrões de } \\
\text { codificação e nomenclaturas definidos pela empresa que os } \\
\text { desenvolverá. }\end{array}$ & $\mathrm{M}$ \\
\hline $\begin{array}{l}\text { Deve ser definido um padrão para todas as especificações e } \\
\text { documentações do projeto. }\end{array}$ & $\mathrm{M}$ \\
\hline
\end{tabular}

Quadro 1 - Requisitos do ponto de vista número 001

\begin{tabular}{|c|c|}
\hline Ponto de Vista: Analista de Sistemas & lúmero: 002 \\
\hline \multicolumn{2}{|c|}{$\begin{array}{l}\text { Foco: Elaborar as especificações do sistema (funcional, interfaces e de } \\
\text { implementação), implementar e testar o sistema. } \\
\text { Objetivos: Desenvolver o Sistema de Transponders obedecendo à } \\
\text { especificação de requisitos do sistema. } \\
\text { Fontes: Especificação de requisitos, especificações dos sistemas atuais. }\end{array}$} \\
\hline Requisitos & Prioridades \\
\hline $\begin{array}{l}\text { Especificação de requisitos deve estar consistente e sem } \\
\text { ambigüidades. }\end{array}$ & A \\
\hline $\begin{array}{l}\text { Ferramentas para desenvolvimento, depuração e gravação } \\
\text { dos programas nos respectivos equipamentos. }\end{array}$ & $\mathrm{M}$ \\
\hline $\begin{array}{l}\text { Programas de Teste para simulação dos Transponders, Bases } \\
\text { e Servidor Central. }\end{array}$ & $\mathrm{B}$ \\
\hline Banco de Dados SQL Server. & M \\
\hline Analisador de protocolos. & $\mathrm{M}$ \\
\hline Protótipo dos equipamentos Transponder e Base. & $\mathrm{M}$ \\
\hline $\begin{array}{l}\text { Definição do modelo a ser adotado nas especificações e } \\
\text { codificação dos programas. }\end{array}$ & $\mathrm{M}$ \\
\hline
\end{tabular}


continuação

\begin{tabular}{|l|c|}
\hline \multicolumn{1}{|c|}{ Requisitos } & Prioridades \\
\hline $\begin{array}{l}\text { O software desenvolvido para o Transponder e para a Base } \\
\text { deve ser desenvolvido na linguagem de programação "C". }\end{array}$ & $\mathrm{M}$ \\
\hline $\begin{array}{l}\text { O software desenvolvido para o Servidor Central deve ser feito } \\
\text { na linguagem de programação JAVA. }\end{array}$ & $\mathrm{M}$ \\
\hline $\begin{array}{l}\text { O software desenvolvido para o Transponder e para a Base } \\
\text { deve ser tolerante a falhas, ou seja, deve executar } \\
\text { procedimentos de recuperação de erros, voltando ao estado } \\
\text { operacional, sem que haja intervenção humana. }\end{array}$ & $\mathrm{A}$ \\
\hline $\begin{array}{l}\text { O acesso aos relatórios e cadastros do sistema deve ser } \\
\text { controlado. Apenas usuários devidamente autorizados podem } \\
\text { ter acesso às informações. }\end{array}$ & $\mathrm{A}$ \\
\hline $\begin{array}{l}\text { Devem ser definidas categorias de acesso aos usuários do } \\
\text { sistema. Algumas operações somente poderão ser realizadas } \\
\text { pelo usuário "administrador do sistema". }\end{array}$ & $\mathrm{M}$ \\
\hline
\end{tabular}

Quadro 2 - Requisitos do ponto de vista número 002 
Ponto de Vista: Gerente de Suporte Técnico

Número: 003

Foco: Atender chamados de clientes e usuários, solucionando suas dúvidas, e sempre que possível fornecer uma solução para seus problemas.

Objetivos: Fornecer aos clientes e usuários um atendimento rápido e de qualidade.

Fontes: Especificação funcional do sistema, manuais de instalação e operação do sistema.

\begin{tabular}{|c|c|}
\hline Requisitos & Prioridades \\
\hline $\begin{array}{l}\text { Aumento da equipe para atendimento } 24 \text { horas, } 7 \text { dias por } \\
\text { semana. }\end{array}$ & $\mathrm{M}$ \\
\hline $\begin{array}{l}\text { Os manuais de instalação e operação dos equipamentos } \\
\text { devem ser claros e de linguagem simples. }\end{array}$ & $\mathrm{M}$ \\
\hline $\begin{array}{l}\text { A instalação dos equipamentos deve ser simples para } \\
\text { minimizar as chamadas ao suporte técnico. }\end{array}$ & $B$ \\
\hline $\begin{array}{l}\text { O Transponder deve ter leds com cores distintas, indicando } \\
\text { seu estado de operação. }\end{array}$ & $\mathrm{M}$ \\
\hline $\begin{array}{l}\text { Uma Base deve sair de fábrica com todas as configurações } \\
\text { necessárias para sua operação. O instalador deverá precisar } \\
\text { apenas conectá-la à rede elétrica (tomada } 110 \mathrm{~V} \text { ou } 220 \mathrm{~V} \text { ). }\end{array}$ & $\mathrm{M}$ \\
\hline $\begin{array}{l}\text { A Base deve ter leds com cores distintas, para indicar seu } \\
\text { estado de operação. }\end{array}$ & $\mathrm{M}$ \\
\hline $\begin{array}{l}\text { O Servidor Central deve disponibilizar ao suporte técnico, } \\
\text { comandos e relatórios para o envio e recepção de dados das } \\
\text { Bases, a qualquer momento. }\end{array}$ & $A$ \\
\hline $\begin{array}{l}\text { Atualização remota dos programas e configurações dos } \\
\text { Transponders e Bases. }\end{array}$ & $A$ \\
\hline
\end{tabular}


continuação

\begin{tabular}{|c|c|}
\hline Requisitos & Prioridades \\
\hline $\begin{array}{l}\text { Funções para verificação remota do status de uma Base ou } \\
\text { Transponder. }\end{array}$ & $\mathrm{M}$ \\
\hline $\begin{array}{l}\text { Extração remota de logs das operações realizadas por uma } \\
\text { Base ou Transponder. }\end{array}$ & $\mathrm{B}$ \\
\hline $\begin{array}{l}\text { Detalhamento de todas as versões do sistema na } \\
\text { especificação funcional. }\end{array}$ & $\mathrm{M}$ \\
\hline $\begin{array}{l}\text { Emissão automática pelo sistema de relatórios de Bases e } \\
\text { Transponders com possíveis problemas. }\end{array}$ & $A$ \\
\hline $\begin{array}{l}\text { O Servidor Central deverá ter estrutura duplicada de } \\
\text { hardware. }\end{array}$ & $A$ \\
\hline $\begin{array}{l}\text { Acesso rápido e fácil ao cadastro das Bases e Transponders } \\
\text { no sistema. }\end{array}$ & $A$ \\
\hline $\begin{array}{l}\text { Mesmo que não existam eventos de Transponder para enviar, } \\
\text { a Base deverá enviar, de tempos em tempos, uma mensagem } \\
\text { com seu estado operacional ao Servidor Central. }\end{array}$ & $A$ \\
\hline $\begin{array}{l}\text { O sistema de monitoramento deve informar ao Sistema de } \\
\text { Transponders quando não receber a passagem de um veículo } \\
\text { por uma Base, localizada entre duas outras que reportaram a } \\
\text { passagem deste veículo (isto pode indicar que a Base está } \\
\text { inoperante). Ao receber este aviso, o sistema deverá emitir um } \\
\text { alerta de Base com suspeita de problemas. }\end{array}$ & $\mathrm{M}$ \\
\hline
\end{tabular}

Quadro 3 - Requisitos do ponto de vista número 003 


\begin{abstract}
\begin{tabular}{|l|l|}
\hline Ponto de Vista: Engenheiro de Produção & Número: 004
\end{tabular}
Foco: Projetar e definir os componentes dos equipamentos, desenvolver protótipos dos equipamentos, gerenciar o processo de produção em larga escala dos equipamentos, elaborar os manuais de instalação das Bases e Transponders.
\end{abstract}

Objetivos: Produzir equipamentos de qualidade, que obedeçam as normas da Anatel e que atendam os requisitos dos clientes, dos usuários e da empresa.

Fontes: Especificação de requisitos, normas ISO 9000, normas da Anatel.

\begin{tabular}{|l|c|}
\hline \multicolumn{1}{|c|}{ Requisitos } & Prioridades \\
\hline $\begin{array}{l}\text { A escolha definitiva dos componentes do Transponder e da } \\
\text { Base deve ser feita após a conclusão dos testes com os } \\
\text { protótipos. }\end{array}$ & M \\
\hline Programas de teste para linha de produção. & A \\
\hline $\begin{array}{l}\text { As embalagens para transporte do Transponder e da Base } \\
\text { devem ser projetadas para comportar o manual de instalação } \\
\text { e o de operação, além dos respectivos acessórios. }\end{array}$ & A \\
\hline $\begin{array}{l}\text { Os procedimentos de fabricação e manutenção dos } \\
\text { equipamentos devem seguir as normas ISO 9000, para } \\
\text { obtenção da certificação correspondente. }\end{array}$ & M \\
\hline $\begin{array}{l}\text { Deve ser definido um local apropriado para os testes das } \\
\text { Bases e dos Transponders fabricados. }\end{array}$ & B \\
\hline $\begin{array}{l}\text { No Servidor Central devem existir relatórios para análise e } \\
\text { aprovação dos testes dos equipamentos. }\end{array}$ & \\
\hline $\begin{array}{l}\text { As Bases devem operar tanto na voltagem 110V quanto na } \\
\text { instador). }\end{array}$ & \\
\hline
\end{tabular}


continuação

\begin{tabular}{|l|c|}
\hline \multicolumn{1}{|c|}{ Requisitos } & Prioridades \\
\hline $\begin{array}{l}\text { Os Transponders devem ser alimentados pela bateria do } \\
\text { veículo onde forem instalados. Portanto devem operar com } \\
\text { voltagens de 12V ou 24V. }\end{array}$ & $\mathrm{A}$ \\
\hline $\begin{array}{l}\text { O consumo de energia de uma Base deve ser igual ou inferior } \\
\text { ao de uma lâmpada de 5W. }\end{array}$ & $\mathrm{M}$ \\
\hline $\begin{array}{l}\text { Receber dos departamentos de Suporte Técnico e de } \\
\text { Manutenção relatórios de problemas e dificuldades com o } \\
\text { sistema, que sejam relacionadas ao hardware dos } \\
\text { equipamentos. }\end{array}$ & $\mathrm{M}$ \\
\hline
\end{tabular}

Quadro 4 - Requisitos do ponto de vista número 004

\begin{tabular}{|l|l|}
\hline Ponto de Vista: Engenheiro de Manutenção & Número: 005 \\
\hline
\end{tabular}

Foco: Receber equipamentos enviados para a assistência técnica, identificar e solucionar os problemas dos equipamentos, desenvolver os equipamentos revisados aos usuários.

Objetivos: Consertar os equipamentos recebidos no menor tempo possível, garantindo a qualidade do serviço realizado.

Fontes: Especificações técnicas dos equipamentos e de seus componentes, manual de operação dos equipamentos.

\begin{tabular}{|l|c|}
\hline \multicolumn{1}{|c|}{ Requisitos } & Prioridades \\
\hline $\begin{array}{l}\text { Quando uma Base ou um Transponder for enviado para } \\
\text { manutenção, deverá ser enviado junto, um relatório sobre o } \\
\text { ocorrido. }\end{array}$ & $\mathrm{M}$ \\
\hline $\begin{array}{l}\text { As Bases devem operar conectadas a redes elétricas com } \\
\text { voltagens de 110V e 220V. }\end{array}$ & $\mathrm{A}$ \\
\hline
\end{tabular}


continuação

\begin{tabular}{|l|c|}
\hline \multicolumn{1}{|c|}{ Requisitos } & Prioridades \\
\hline $\begin{array}{l}\text { Laboratório com ferramentas necessárias para a avaliação e } \\
\text { reparo dos equipamentos recebidos para manutenção. }\end{array}$ & $\mathrm{A}$ \\
\hline $\begin{array}{l}\text { Para a troca de componentes defeituosos, deverá existir um } \\
\text { estoque de reposição completo no departamento de } \\
\text { manutenção. }\end{array}$ & $\mathrm{M}$ \\
\hline $\begin{array}{l}\text { Deverão existir documentações claras e completas sobre os } \\
\text { procedimentos de teste e homologação dos equipamentos } \\
\text { recebidos para manutenção. }\end{array}$ & $\mathrm{A}$ \\
\hline
\end{tabular}

Quadro 5 - Requisitos do ponto de vista número 005

\begin{tabular}{|l|l|}
\hline Ponto de Vista: Gerente Comercial & Número: 006 \\
\hline
\end{tabular}

Foco: Definir o perfil dos clientes e usuários finais que o sistema deverá atender, definir a faixa de preço desejada para o sistema, divulgar e vender o sistema.

Objetivos: Vender a maior quantidade de equipamentos e serviços do novo sistema.

Fontes: Necessidades do mercado de transporte rodoviário de cargas, produtos já existentes no mercado.

\begin{tabular}{|l|c|}
\hline \multicolumn{1}{|c|}{ Requisitos } & Prioridades \\
\hline $\begin{array}{l}\text { O preço final do Sistema de Transponders deve ser muito } \\
\text { inferior ao de um sistema de rastreamento. }\end{array}$ & $\mathrm{A}$ \\
\hline $\begin{array}{l}\text { O hardware do Transponder e da Base deve ser resistente e } \\
\text { robusto, evitando gastos com manutenção para o usuário. }\end{array}$ & $\mathrm{A}$ \\
\hline $\begin{array}{l}\text { Para redução de custo, o hardware dos equipamentos deve } \\
\text { ser projetado com o mínimo de memória para gravação de } \\
\text { dados. }\end{array}$ & $\mathrm{A}$ \\
\hline
\end{tabular}


continuação

\begin{tabular}{|c|c|}
\hline Requisitos & Prioridades \\
\hline $\begin{array}{l}\text { O Transponder deve ser instalado em veículos que não } \\
\text { tenham sistema de rastreamento, e que necessitem do } \\
\text { produto para o monitoramento logístico de suas viagens. }\end{array}$ & $\mathrm{M}$ \\
\hline $\begin{array}{l}\text { O Transponder deve ser um equipamento de pequeno porte. } \\
\text { Suas dimensões não devem exceder } 12 \text { centímetros de } \\
\text { comprimento por } 6 \text { centímetros de largura e } 2 \text { centímetros de } \\
\text { altura, pois deverá ser instalado no painel do veículo. }\end{array}$ & $B$ \\
\hline $\begin{array}{l}\text { A caixa externa do Transponder deve ser confeccionada em } \\
\text { material plástico e leve, para que não emita ruídos de } \\
\text { trepidação no painel do veículo. }\end{array}$ & B \\
\hline $\begin{array}{l}\text { Caso o Transponder seja alimentado pela bateria do veículo, } \\
\text { seu consumo deve ser mínimo. }\end{array}$ & $A$ \\
\hline $\begin{array}{l}\text { Qualquer eletricista automotivo deve ser capaz de instalar o } \\
\text { Transponder, apenas com o auxílio do manual de instalação. }\end{array}$ & $A$ \\
\hline $\begin{array}{l}\text { O Servidor Central deve disponibilizar aos usuários, relatórios } \\
\text { que forneçam o maior número de informações sobre os } \\
\text { Transponders em utilização. }\end{array}$ & $A$ \\
\hline $\begin{array}{l}\text { Os usuários devem ter acesso às informações do Servidor } \\
\text { Central através da internet, } 24 \text { horas por dia. }\end{array}$ & A \\
\hline $\begin{array}{l}\text { As Bases devem operar ininterruptamente ( } 24 \text { horas, } 365 \text { dias } \\
\text { por ano). }\end{array}$ & $A$ \\
\hline $\begin{array}{l}\text { Nas localidades onde for possível, a comunicação entre as } \\
\text { Bases e o Servidor Central deve ser feita através de uma } \\
\text { conexão GPRS. }\end{array}$ & $B$ \\
\hline $\begin{array}{l}\text { O Servidor Central deve ser dimensionado para receber dados } \\
\text { de até } 500 \text { Bases simultaneamente. Nesta situação, o tempo } \\
\text { de resposta não pode aumentar muito. }\end{array}$ & $\mathrm{M}$ \\
\hline
\end{tabular}


continuação

\begin{tabular}{|l|c|}
\hline \multicolumn{1}{|c|}{ Requisitos } & Prioridades \\
\hline $\begin{array}{l}\text { A base de dados do Servidor Central deve ser dimensionada } \\
\text { para armazenar os dados recebidos e enviados nos últimos } 2 \\
\text { anos. }\end{array}$ & $\mathrm{M}$ \\
\hline
\end{tabular}

Quadro 6 - Requisitos do ponto de vista número 006

\begin{tabular}{|c|c|}
\hline $\begin{array}{l}\text { Ponto de Vista: Homologador (responsável pela } \\
\text { homologação do produto) }\end{array}$ & Número: 007 \\
\hline \multicolumn{2}{|c|}{$\begin{array}{l}\text { Foco: Testar o sistema, verificar se o sistema desenvolvido está consistente } \\
\text { com as especificações funcional e de requisitos. } \\
\text { Objetivos: Melhorar a qualidade do sistema através da detecção e } \\
\text { notificação de erros e inconsistências. } \\
\text { Fontes: Especificações de requisitos e funcional do sistema, normas da } \\
\text { Anatel. }\end{array}$} \\
\hline Requisitos & Prioridades \\
\hline $\begin{array}{l}\text { Especificação de requisitos deve estar consistente e sem } \\
\text { ambigüidades. }\end{array}$ & A \\
\hline Especificação funcional do sistema. & A \\
\hline $\begin{array}{l}\text { Especificação da interface do Servidor Central com os } \\
\text { usuários. }\end{array}$ & A \\
\hline Programas de teste. & M \\
\hline Equipamentos (Transponders e Bases) para teste. & A \\
\hline Acesso a todas as funções disponíveis no Servidor Central. & A \\
\hline $\begin{array}{l}\text { Todo software e hardware desenvolvido para a comunicação } \\
\text { entre os equipamentos devem obedecer às normas da Anatel } \\
\text { para equipamentos de radiação restrita. }\end{array}$ & A \\
\hline
\end{tabular}


continuação

\begin{tabular}{|l|c|}
\hline \multicolumn{1}{|c|}{ Requisitos } & Prioridades \\
\hline Se alguma parte do sistema necessitar de software de & $\mathrm{A}$ \\
terceiros, devem ser adquiridas junto ao fornecedor deste \\
software, tantas cópias quantas forem necessárias.
\end{tabular}

Quadro 7 - Requisitos do ponto de vista número 007

\subsubsection{Requisitos da Classe Cliente}

Ponto de Vista: Analista de Riscos

Número: 008

Foco: Receber detalhes das rotas das viagens, receber avisos de passagem de um veículo pelas Bases, identificar situações de roubo ou acidente em uma viagem e tomar as providências necessárias.

Objetivos: Acompanhar passagens dos veículos pelas Bases, identificando e prevenindo situações de risco (sinistros).

Fontes: Mapas de ruas e estradas, roteiro planejado das viagens dos veículos.

\begin{tabular}{|l|c|}
\hline \multicolumn{1}{|c|}{ Requisitos } & Prioridades \\
\hline Acesso ao cadastro de todas as Bases instaladas. & $\mathrm{A}$ \\
\hline $\begin{array}{l}\text { O cadastro das Bases deve conter o endereço completo, } \\
\text { nome da empresa, nome do responsável e as coordenadas } \\
\text { geográficas (latitude e longitude) do ponto onde a Base está } \\
\text { instalada. }\end{array}$ & $\mathrm{A}$ \\
\hline $\begin{array}{l}\text { A área de cobertura da rede de Bases instaladas deve } \\
\text { abranger todas as principais rotas de transporte de cargas. }\end{array}$ & $\mathrm{A}$ \\
\hline $\begin{array}{l}\text { As Bases deverão permanecer operacionais 24 horas por dia, } \\
7 \text { dias por semana, captando informações de todos os } \\
\text { Transponders que passarem por sua área de cobertura. }\end{array}$ & $\mathrm{A}$ \\
\hline
\end{tabular}


continuação

\begin{tabular}{|c|c|}
\hline Requisitos & Prioridades \\
\hline $\begin{array}{l}\text { As Bases deverão informar a passagem de um veículo ao } \\
\text { Servidor Central no menor tempo possível (ideal: }<15 \\
\text { minutos). }\end{array}$ & $A$ \\
\hline $\begin{array}{l}\text { Em caso de roubo de veículo com Transponder, deve ser } \\
\text { possível informar as Bases para que estas dêem prioridade ao } \\
\text { envio da passagem deste veículo na sua área de cobertura. }\end{array}$ & $\mathrm{M}$ \\
\hline $\begin{array}{l}\text { Algumas estradas não fazem parte das principais rotas de } \\
\text { transporte de carga, porém são freqüentemente utilizadas } \\
\text { como "rota de fuga", em caso de roubo do veículo. Sendo } \\
\text { assim, devem ser previstas instalações de Bases em alguns } \\
\text { pontos destas estradas. }\end{array}$ & $\mathrm{B}$ \\
\hline $\begin{array}{l}\text { O sistema de monitoramento deve emitir um alerta caso } \\
\text { receba uma passagem de veículo por uma Base instalada em } \\
\text { uma possível "rota de fuga", ou fora da rota prevista. }\end{array}$ & $\mathrm{M}$ \\
\hline $\begin{array}{l}\text { Em caso de perda de alimentação (queda de energia), a Base } \\
\text { não poderá perder os dados armazenados e ainda não } \\
\text { transmitidos para o Servidor Central. }\end{array}$ & $A$ \\
\hline $\begin{array}{l}\text { Em caso de perda de alimentação, o Transponder não poderá } \\
\text { perder os dados armazenados e nem suas configurações. }\end{array}$ & $\mathrm{M}$ \\
\hline $\begin{array}{l}\text { As Bases devem ser instaladas em locais seguros para que } \\
\text { não tenham risco de roubo ou depredações. }\end{array}$ & $\mathrm{M}$ \\
\hline $\begin{array}{l}\text { Os Transponders devem ser instalados na parte interna dos } \\
\text { veículos para evitar roubo ou depredações. }\end{array}$ & $\mathrm{M}$ \\
\hline
\end{tabular}

Quadro 8 - Requisitos do ponto de vista número 008 


\begin{abstract}
Ponto de Vista: Analista de Sistemas
Número: 009

Foco: Especificar e implementar alterações no sistema atual para a integração com o Sistema de Transponders, especificar novos programas que utilizem as informações recebidas para melhorar os processos da empresa.
\end{abstract}

Objetivos: Adaptar e aperfeiçoar os sistemas atuais da empresa.

Fontes: Especificação funcional do sistema, especificações dos sistemas atuais.

\begin{tabular}{|l|c|}
\hline \multicolumn{1}{|c|}{ Requisitos } & Prioridades \\
\hline $\begin{array}{l}\text { Definição de um formato para a troca de informações entre o } \\
\text { sistema de monitoramento e o Sistema de Transponders. }\end{array}$ & $\mathrm{A}$ \\
\hline $\begin{array}{l}\text { A troca de informações entre os sistemas deve ser feita } \\
\text { através da web (Internet). }\end{array}$ & $\mathrm{M}$ \\
\hline $\begin{array}{l}\text { O protocolo utilizado para troca de informações entre os } \\
\text { sistemas deve ser o XML, e os dados devem estar } \\
\text { criptografados. }\end{array}$ & $\mathrm{M}$ \\
\hline $\begin{array}{l}\text { O Servidor Central deve estar disponível 24 horas por dia, 7 } \\
\text { dias por semana. }\end{array}$ & $\mathrm{A}$ \\
\hline $\begin{array}{l}\text { O Servidor Central deve informar aos demais sistemas, as } \\
\text { alterações no cadastro de Bases e Transponders. }\end{array}$ & $\mathrm{M}$ \\
\hline $\begin{array}{l}\text { Receber avisos do Servidor Central, quando uma Base } \\
\text { apresentar problemas de comunicação, assim como quando } \\
\text { ela voltar a sua operação normal. }\end{array}$ & $\mathrm{A}$ \\
\hline
\end{tabular}

Quadro 9 - Requisitos do ponto de vista número 009 
Ponto de Vista: Gerente de Logística

Número: 010

Foco: Receber detalhes das rotas das viagens, receber avisos de passagem de um veículo pelas Bases, fornecer aos usuários o status atual de cada viagem.

Objetivos: Acompanhar passagens dos veículos pelas Bases, fornecendo o status da viagem aos usuários.

Fontes: Mapas de ruas e estradas, roteiro planejado das viagens.

\begin{tabular}{|l|c|}
\hline \multicolumn{1}{|c|}{ Requisitos } & Prioridades \\
\hline $\begin{array}{l}\text { O cadastro das Bases deve conter o endereço completo, } \\
\text { nome da empresa e as coordenadas geográficas (latitude e } \\
\text { longitude), do ponto onde cada Base está instalada. }\end{array}$ & A \\
\hline $\begin{array}{l}\text { A área de cobertura da rede de Bases instaladas deverá } \\
\text { cobrir todas as principais rotas de transporte de carga. }\end{array}$ & $\mathrm{A}$ \\
\hline $\begin{array}{l}\text { Além das estradas, deverão ser instaladas Bases nos pátios } \\
\text { das transportadoras e grandes embarcadores. }\end{array}$ & $\mathrm{M}$ \\
\hline $\begin{array}{l}\text { O Transponder deve ser capaz de trocar informações com } \\
\text { uma Base, mesmo que existam outros Transponders } \\
\text { operando na mesma área (um não pode atrapalhar o outro). }\end{array}$ & $\mathrm{A}$ \\
\hline $\begin{array}{l}\text { As Bases instaladas em pátios de transportadoras e grandes } \\
\text { embarcadores devem suportar a troca de informações com } \\
\text { centenas de veículos, simultaneamente (um pátio pode ter até } \\
\text { 300 veículos estacionados). }\end{array}$ & $\mathrm{M}$ \\
\hline $\begin{array}{l}\text { Uma Base deve ter a capacidade de armazenar informações } \\
\text { recebidas dos Transponders durante vários dias, prevendo-se } \\
\text { o caso de problemas na comunicação com o Servidor Central. }\end{array}$ & $\mathrm{M}$ \\
\hline
\end{tabular}


continuação

\begin{tabular}{|l|c|}
\hline \multicolumn{1}{|c|}{ Requisitos } & Prioridades \\
\hline $\begin{array}{l}\text { Toda vez que estabelecer comunicação com um Transponder, } \\
\text { a Base deverá enviar um evento de "passagem" para o } \\
\text { Servidor Central, informando todos os dados obtidos. Nestes } \\
\text { dados devem constar também a data e o horário que o veículo } \\
\text { chegou e saiu da área de cobertura desta Base. }\end{array}$ & \\
\hline $\begin{array}{l}\text { O sistema de monitoramento deve conhecer as Bases que um } \\
\text { veículo deve passar em uma viagem, assim como o tempo } \\
\text { gasto estimado entre elas. Em caso de atraso, ou passagem } \\
\text { por uma base fora da rota, deve ser emitido um alerta ao } \\
\text { operador deste sistema. }\end{array}$ & A \\
\hline $\begin{array}{l}\text { O Transponder deve monitorar e armazenar informações } \\
\text { sobre o veículo, tais como: situação atual do motor (ligado ou } \\
\text { desligado), tempo total que o motor está ligado ou desligado, } \\
\text { etc. }\end{array}$ & $\mathrm{M}$ \\
\hline $\begin{array}{l}\text { Ao conectar-se à uma Base, o Transponder deve transmitir } \\
\text { todas as informações armazenadas sobre o veículo (se o } \\
\text { motor do veículo está ligado ou desligado, etc.). }\end{array}$ & $\mathrm{M}$ \\
visualização será mais clara se estas informações forem \\
exibidas em um mapa (graficamente).
\end{tabular}

Quadro 10 - Requisitos do ponto de vista número 010 


\subsubsection{Requisitos da Classe Usuário Final}

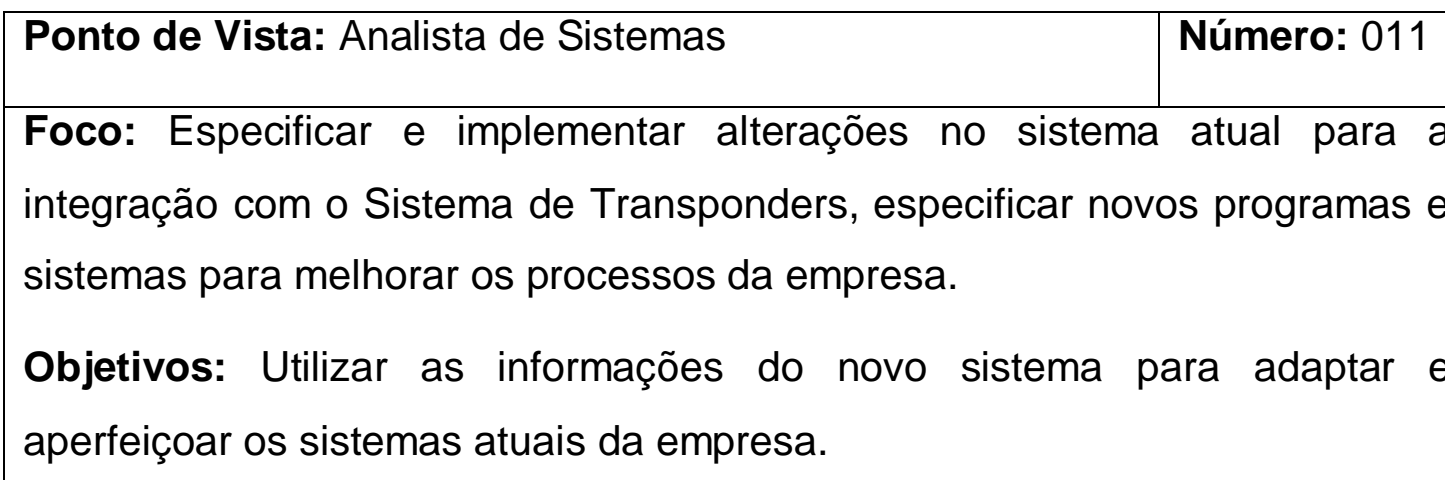

Fontes: Especificação funcional do sistema, especificações dos sistemas atuais.

\begin{tabular}{|l|c|}
\hline \multicolumn{1}{|c|}{ Requisitos } & Prioridades \\
\hline $\begin{array}{l}\text { Ferramenta para o cadastro de novos Transponders } \\
\text { instalados, integrada ao sistema atual (da transportadora ou } \\
\text { embarcador). }\end{array}$ & $\mathrm{A}$ \\
\hline $\begin{array}{l}\text { O cadastro de um Transponder deve conter todos os dados } \\
\text { do veículo no qual ele foi instalado. }\end{array}$ & $\mathrm{A}$ \\
\hline $\begin{array}{l}\text { Definição de um formato para troca de informações com o } \\
\text { Servidor Central. }\end{array}$ & $\mathrm{A}$ \\
\hline $\begin{array}{l}\text { A troca de informações entre os sistemas deve ser feita } \\
\text { através da web (Internet), de preferência, utilizando o } \\
\text { protocolo XML. }\end{array}$ & $\mathrm{M}$ \\
\hline $\begin{array}{l}\text { As Bases e Transponders devem ser identificadas nos } \\
\text { sistemas por um número de identificação único. Todas as } \\
\text { informações sobre eles devem conter este número. }\end{array}$ & $\mathrm{A}$ \\
\hline $\begin{array}{l}\text { Receber todas as alterações cadastrais das Bases. } \\
\text { visualização das rotas dos veículos em mapas. }\end{array}$ & $\mathrm{M}$ \\
\hline $\begin{array}{l}\text { Ferramenta gráfica para a criação de programas de cadastro e } \\
\text { (n) }\end{array}$ & \\
\hline
\end{tabular}

Quadro 11 - Requisitos do ponto de vista número 011 
Ponto de Vista: Gerente de Logística

Número: 012

Foco: Definir as rotas das viagens, receber avisos de passagem dos veículos pelas Bases, fornecer aos usuários posições sobre entregas de cargas.

Objetivos: Aprimorar as operações de entrega de cargas e as informações disponibilizadas aos usuários.

Fontes: Mapas de ruas e estradas, relação da rede de Bases, pedidos de coleta e entrega de cargas.

\begin{tabular}{|l|c|}
\hline \multicolumn{1}{|c|}{ Requisitos } & Prioridades \\
\hline A interface do sistema do usuário deve ser simples e clara. & $\mathrm{M}$ \\
\hline $\begin{array}{l}\text { O cadastro dos Transponders (instalação ou troca) deve ser } \\
\text { feito no sistema do usuário, e este deve enviar as informações } \\
\text { ao Sistema de Transponders. }\end{array}$ & $\mathrm{A}$ \\
\hline $\begin{array}{l}\text { Funções de acompanhamento, relatórios e consultas devem } \\
\text { ser associadas aos veículos e as viagens. O usuário não } \\
\text { precisará utilizar a identificação do Transponder em suas } \\
\text { operações diárias. }\end{array}$ & $\mathrm{M}$ \\
\hline $\begin{array}{l}\text { O sistema da empresa (transportadora ou embarcador) deve } \\
\text { permitir o cadastro diário da rota de cada veículo, assim como } \\
\text { os horários previstos de chegada em cada ponto. }\end{array}$ & $\mathrm{A}$ \\
\hline $\begin{array}{l}\text { Receber a data e a hora exatas da passagem de um veículo } \\
\text { por uma Base. }\end{array}$ & $\mathrm{A}$ \\
\hline $\begin{array}{l}\text { Se o veículo permanecer por um tempo nesta Base, o Sistema } \\
\text { de } \begin{array}{l}\text { Transponders deve informar também o } \\
\text { permanência no local. } \\
\text { que voltarem a operar. }\end{array}\end{array}$ \\
\hline
\end{tabular}


continuação

\begin{tabular}{|l|c|}
\hline \multicolumn{1}{|c|}{ Requisitos } & Prioridades \\
\hline $\begin{array}{l}\text { Possibilidade de consultar o andamento de uma viagem em } \\
\text { um mapa (em que Bases o veículo já passou e quais ainda } \\
\text { faltam). }\end{array}$ & $\mathrm{M}$ \\
\hline $\begin{array}{l}\text { Possibilidade de extrair relatórios de passagens em Bases, } \\
\text { selecionados por: período de tempo, por Transponder ou por } \\
\text { viagem. }\end{array}$ & $\mathrm{M}$ \\
\hline $\begin{array}{l}\text { Apesar do motorista do veículo ter acesso ao Transponder, } \\
\text { não deverão existir operações para ele executar. }\end{array}$ & $\mathrm{B}$ \\
\hline $\begin{array}{l}\text { O sistema do usuário deve emitir um alerta sempre que } \\
\text { receber uma passagem de um veículo por uma Base que } \\
\text { esteja fora da rota prevista, ou foram do tempo estimado. }\end{array}$ & $\mathrm{M}$ \\
\hline $\begin{array}{l}\text { A informação de passagem de um veículo por uma Base deve } \\
\text { conter dados sobre o motor naquele momento. }\end{array}$ & B \\
\hline
\end{tabular}

Quadro 12 - Requisitos do ponto de vista número 012

Ponto de Vista: Motorista do Veículo

Número: 013

Foco: Seguir o roteiro da viagem, fazer entregas e coletas, verificar se 0 equipamento Transponder está ligado antes de iniciar uma viagem.

Objetivos: Executar o roteiro programado para a viagem, sem se preocupar com passagem de cartão ou telefonemas para a transportadora.

Fontes: Roteiro de viagem, manual de operação do Transponder.

\begin{tabular}{|l|c|}
\hline \multicolumn{1}{|c|}{ Requisitos } & Prioridades \\
\hline O Transponder deve possuir indicações sonoras ou & B \\
luminosas, para indicação de status de operação. Estas & \\
indicações não podem incomodar o motorista, principalmente \\
a noite.
\end{tabular}


continuação

\begin{tabular}{|l|c|}
\hline \multicolumn{1}{|c|}{ Requisitos } & Prioridades \\
\hline O Transponder não pode atrapalhar o motorista. & A \\
\hline $\begin{array}{l}\text { Caso o Transponder esteja instalado dentro do painel do } \\
\text { veículo (não visível), deve de tempos em tempos emitir um } \\
\text { som específico, informando ao motorista que está operando } \\
\text { sem problemas. }\end{array}$ & B \\
\hline $\begin{array}{l}\text { O motorista não deve ter que executar nenhuma operação no } \\
\text { Transponder. Caso detecte algum comportamento } \\
\text { inadequado do equipamento (através das luzes e sons), deve } \\
\text { informar ao suporte técnico da empresa responsável, que } \\
\text { tomará as providências necessárias. }\end{array}$ & A \\
\hline $\begin{array}{l}\text { A instalação do Transponder não pode causar nenhum tipo de } \\
\text { dano ao veículo. }\end{array}$ & A \\
\hline $\begin{array}{l}\text { O consumo de energia do Transponder deve ser baixo para } \\
\text { não consumir em excesso a bateria do veículo. }\end{array}$ & \\
\hline
\end{tabular}

Quadro 13 - Requisitos do ponto de vista número 013

Ponto de Vista: Eletricista Automotivo

Número: 014

Foco: Instalar Transponder nos veículos, substituir Transponders com problema.

Objetivos: Instalar o Transponder em um veículo, somente com a ajuda do manual de instalação do mesmo.

Fontes: Manual de instalação do Transponder, manual do veículo.

\begin{tabular}{|l|c|}
\hline \multicolumn{1}{|c|}{ Requisitos } & Prioridades \\
\hline O manual de instalação deve conter todos os passos de \\
instalação detalhados e com fotos ilustrativas.
\end{tabular}


continuação

\begin{tabular}{|l|c|}
\hline \multicolumn{1}{|c|}{ Requisitos } & Prioridades \\
\hline $\begin{array}{l}\text { A instalação do Transponder deve ser simples e rápida, sem } \\
\text { que haja necessidade de um treinamento específico. Qualquer } \\
\text { eletricista automotivo deve conseguir instalá-lo. }\end{array}$ & $\mathrm{M}$ \\
\hline $\begin{array}{l}\text { Uma instalação de Transponder não deve consumir mais de 1 } \\
\text { hora de um eletricista. }\end{array}$ & $\mathrm{A}$ \\
\hline $\begin{array}{l}\text { O Transponder deve vir de fábrica com fitas adesivas e } \\
\text { demais acessórios, para fixação no veículo. }\end{array}$ & $\mathrm{B}$ \\
\hline $\begin{array}{l}\text { Após uma instalação, deve existir um procedimento simples } \\
\text { para que o eletricista possa verificar se o Transponder está } \\
\text { operando corretamente. }\end{array}$ & $\mathrm{M}$ \\
\hline
\end{tabular}

Quadro 14 - Requisitos do ponto de vista número 014 


\subsection{Análise e Negociação dos Requisitos}

Dentre as técnicas sugeridas na ER para esta etapa do processo, opto-se pela aplicação de reuniões como ferramenta básica para a análise e negociação dos requisitos até então levantados.

A análise e a negociação de requisitos pode ser uma etapa demorada, que pode implicar no aumento do custo do projeto. Visando minimizar o tempo gasto nesta atividade, e aproveitar as múltiplas visões dos participantes, no início de cada reunião de levantamento, o gerente do projeto apresentava ao grupo os requisitos obtidos na reunião anterior, propondo uma análise de cada item. Os problemas com requisitos identificados nesta análise eram então discutidos, e o grupo chegava a um consenso sobre as mudanças necessárias em cada requisito.

Ao final da série de reuniões de análise dos requisitos, foram realizadas mais duas reuniões com os principais representantes de cada classe de ponto de vista, para que todos os requisitos já levantados e analisados fossem novamente apresentados para uma validação final do grupo.

A atividade mais trabalhosa destas últimas reuniões foi a negociação dos requisitos conflitantes. Como em quase todos os tipos de sistema, as diversas partes interessadas têm visões e interesses diferentes, que podem entrar em conflito. Para chegarmos a um acordo, em cada um dos casos, foram discutidas diversas alternativas, optando-se pela solução que atendesse ao maior número de interessados, e que não inviabilizasse as premissas e restrições do projeto.

Requisitos duplicados, ambíguos, conflitantes e inconsistentes foram alterados ou eliminados durante as reuniões de análise e negociação, obtendo-se uma lista de requisitos para o sistema proposto. O próximo item apresenta a definição destes requisitos. 


\section{DEFINIÇÃO DOS REQUISITOS PARA O SISTEMA PROPOSTO}

Conforme os métodos seguidos por esta proposta, este item apresenta a definição dos requisitos para o Sistema de Transponders, cujo conteúdo é o resultado da ponderação das informações obtidas nas etapas anteriores.

Seguindo o método Volere, os requisitos identificados e validados para o sistema proposto foram agrupados em funcionais e não funcionais do sistema. Os requisitos não funcionais estão separados por categoria.

Para efeito de controle e rastreabilidade destes requisitos, o número de identificação do ponto de vista que os originou (NPV) está indicado ao lado de cada um.

\subsubsection{Composição do Sistema}

O Sistema de Transponders será composto pelos seguintes equipamentos:

Transponder - instalado nos veículos.

Base - instalada em pontos fixos das rodovias.

Servidor Central - instalado na sede da empresa desenvolvedora do produto.

Cada uma das partes deverá obedecer aos requisitos definidos nos itens a seguir.

\subsubsection{Requisitos de Desenvolvimento}

Esta categoria foi incluída nesta proposta, visando agrupar requisitos que dizem respeito às regras e procedimentos executados durante o desenvolvimento do sistema. 


\begin{tabular}{|c|c|}
\hline Requisitos & NPV \\
\hline $\begin{array}{l}\text { 1. Disponibilidade de todos os recursos alocados para este } \\
\text { projeto. }\end{array}$ & 001 \\
\hline $\begin{array}{l}\text { 2. Facilidade de comunicação com a equipe de } \\
\text { desenvolvimento e com os usuários. }\end{array}$ & 001 \\
\hline 3. O software desenvolvido tem que ser de ótima qualidade. & 001 \\
\hline $\begin{array}{l}\text { 4. Todas as decisões tomadas nas reuniões de projeto } \\
\text { deverão ser registradas em ata. }\end{array}$ & 001 \\
\hline $\begin{array}{l}\text { 5. O desenvolvimento do software deve ser iniciado somente } \\
\text { após a conclusão e a aprovação das especificações de } \\
\text { implementação dos programas. }\end{array}$ & 001 \\
\hline $\begin{array}{l}\text { 6. A especificação de requisitos do sistema deve atender ao } \\
\text { maior número possível de stakeholders. }\end{array}$ & 001 \\
\hline $\begin{array}{l}\text { 7. As especificações de implementação dos programas } \\
\text { devem ser iniciadas somente após a conclusão e a } \\
\text { aprovação das especificações funcional e de interfaces do } \\
\text { sistema. }\end{array}$ & 001 \\
\hline $\begin{array}{l}\text { 8. O desenvolvimento do software deve seguir os padrões de } \\
\text { codificação e nomenclaturas definidos pela empresa que } \\
\text { os desenvolverá. }\end{array}$ & 001 \\
\hline $\begin{array}{l}\text { 9. Deve ser definido um padrão para todas as especificações } \\
\text { e documentações do projeto. }\end{array}$ & 001 \\
\hline $\begin{array}{l}\text { 10. Especificação de requisitos deve estar consistente e sem } \\
\text { ambigüidades. }\end{array}$ & $\begin{array}{l}002 \\
007\end{array}$ \\
\hline $\begin{array}{l}\text { 11. Ferramentas para desenvolvimento, depuração e gravação } \\
\text { dos programas nos respectivos equipamentos. }\end{array}$ & 002 \\
\hline $\begin{array}{l}\text { 12. Programas de Teste para simulação dos Transponders, } \\
\text { Bases e Servidor Central. }\end{array}$ & 002 \\
\hline
\end{tabular}




\begin{tabular}{|c|c|}
\hline Requisitos & NPV \\
\hline 13. Banco de Dados SQL Server. & 002 \\
\hline 14. Analisador de protocolos. & 002 \\
\hline 15. Protótipo dos equipamentos Transponder e Base. & 002 \\
\hline $\begin{array}{l}\text { 16. Definição do modelo a ser adotado nas especificações e } \\
\text { codificação dos programas. }\end{array}$ & 002 \\
\hline $\begin{array}{l}\text { 17. O software desenvolvido para o Transponder e para a Base } \\
\text { deve ser desenvolvido na linguagem de programação " } \mathrm{C} \text { ". }\end{array}$ & 002 \\
\hline $\begin{array}{l}\text { 18. O software desenvolvido para o Servidor Central deve ser } \\
\text { feito na linguagem de programação JAVA. }\end{array}$ & 002 \\
\hline $\begin{array}{l}\text { 19. O software desenvolvido para o Transponder e para a Base } \\
\text { deve ser tolerante a falhas, ou seja, deve executar } \\
\text { procedimentos de recuperação de erros, voltando ao } \\
\text { estado operacional, sem que haja intervenção humana. }\end{array}$ & 002 \\
\hline $\begin{array}{l}\text { 20. A escolha definitiva dos componentes do Transponder e da } \\
\text { Base deve ser feita após a conclusão dos testes com os } \\
\text { protótipos. }\end{array}$ & 004 \\
\hline $\begin{array}{l}\text { 21. Devem ser desenvolvidos programas de teste para } \\
\text { utilização na linha de produção das Bases e dos } \\
\text { Transponders. }\end{array}$ & 004 \\
\hline $\begin{array}{l}\text { 22. Deve ser elaborado um documento de especificação da } \\
\text { interface entre o Sistema de Transponders e os demais } \\
\text { sistemas. }\end{array}$ & 007 \\
\hline $\begin{array}{l}\text { 23. Devem ser desenvolvidos programas de teste para } \\
\text { utilização na homologação do sistema. }\end{array}$ & 007 \\
\hline $\begin{array}{l}\text { 24. Devem ser disponibilizados diversos equipamentos } \\
\text { (Transponders e Bases) para os testes de homologação. }\end{array}$ & 007 \\
\hline
\end{tabular}




\subsubsection{Requisitos Funcionais}

Com relação à funcionalidade, cada uma das partes que compõem o Sistema de Transponders deverá obedecer aos seguintes requisitos:

\begin{tabular}{|l|c|}
\hline \multicolumn{1}{|c|}{ Requisitos } & NPV \\
\hline 1. O Transponder deve ter leds com cores distintas, indicando \\
seu estado de operação. & 003 \\
\hline 2. A Base deve ter leds com cores distintas, indicando seu \\
estado de operação. & 003 \\
\hline 3. Atualização remota dos programas e configurações dos & 003 \\
Transponders e Bases. & \\
\hline 4. Funções para verificação remota do status de uma Base ou & 003 \\
Transponder. & 003 \\
\hline 5. Extração remota de logs das operações realizadas por uma \\
$\begin{array}{l}\text { Base ou Transponder. } \\
\text { 6. O Servidor Central deve emitir, automaticamente, relatórios } \\
\text { de Bases e Transponders com possíveis problemas. }\end{array}$ & 003 \\
\hline 7. O sistema de monitoramento deve informar ao Sistema de \\
$\begin{array}{l}\text { Transponders quando não receber a passagem de um } \\
\text { veículo por uma Base, localizada entre duas outras que } \\
\text { reportaram a passagem deste veículo (isto pode indicar } \\
\text { que a Base está inoperante). Ao receber este aviso, o } \\
\text { sistema deverá emitir um alerta de Base com suspeita de } \\
\text { problemas. }\end{array}$ \\
\hline 8. Mesmo que não existam eventos de Transponder para \\
enviar, a Base deverá enviar, de tempos em tempos, uma \\
mensagem com seu estado operacional ao Servidor \\
Central.
\end{tabular}




\begin{tabular}{|c|c|}
\hline Requisitos & NPV \\
\hline $\begin{array}{l}\text { 9. No Servidor Central devem existir relatórios para análise e } \\
\text { aprovação dos testes dos equipamentos produzidos. }\end{array}$ & 004 \\
\hline $\begin{array}{l}\text { 10.O Servidor Central deve disponibilizar aos usuários, } \\
\text { relatórios que forneçam o maior número de informações } \\
\text { sobre os Transponders em utilização. }\end{array}$ & 006 \\
\hline $\begin{array}{l}\text { 11. Nas localidades onde for possível, a comunicação entre as } \\
\text { Bases e o Servidor Central deve ser feita através de uma } \\
\text { conexão GPRS. }\end{array}$ & 006 \\
\hline $\begin{array}{l}\text { 12. Em caso de roubo de um veículo com Transponder, deve } \\
\text { ser possível informar as Bases para que estas dêem } \\
\text { prioridade ao envio da passagem deste veículo na sua área } \\
\text { de cobertura. }\end{array}$ & 008 \\
\hline $\begin{array}{l}\text { 13. O sistema de monitoramento deve emitir um alerta caso } \\
\text { receba uma passagem de veículo por uma Base instalada } \\
\text { em uma possível "rota de fuga", ou fora da rota prevista. }\end{array}$ & 008 \\
\hline $\begin{array}{l}\text { 14. A troca de informações entre os sistemas dos clientes e } \\
\text { usuários deve ser feita através da web (Internet). }\end{array}$ & $\begin{array}{l}009 \\
011\end{array}$ \\
\hline $\begin{array}{l}\text { 15. O protocolo utilizado para troca de informações entre os } \\
\text { sistemas deve ser o XML, e os dados devem estar } \\
\text { criptografados. }\end{array}$ & $\begin{array}{c}009 \\
011\end{array}$ \\
\hline $\begin{array}{l}\text { 16. O Servidor Central deve informar aos demais sistemas, as } \\
\text { alterações no cadastro de Bases e Transponders. }\end{array}$ & $\begin{array}{c}009 \\
011\end{array}$ \\
\hline $\begin{array}{l}\text { 17. Servidor Central deve enviar avisos aos demais } \\
\text { sistemas, quando uma Base apresentar problemas de } \\
\text { comunicação, assim como quando ela voltar a sua } \\
\text { operação normal. }\end{array}$ & $\begin{array}{l}009 \\
012\end{array}$ \\
\hline
\end{tabular}




\begin{tabular}{|c|c|}
\hline Requisitos & NPV \\
\hline $\begin{array}{l}\text { 18. Ao conectar-se a uma Base, o Transponder deve informar } \\
\text { dados sobre o motor do veículo (ligado ou desligado, } \\
\text { tempo total ligado ou desligado, etc.). }\end{array}$ & $\begin{array}{l}010, \\
012\end{array}$ \\
\hline $\begin{array}{l}\text { 19. Toda vez que estabelecer comunicação com um } \\
\text { Transponder, a Base deverá enviar um evento de } \\
\text { "passagem" para o Servidor Central, informando todos os } \\
\text { dados obtidos. Nestes dados devem constar também a } \\
\text { data e o horário que o veículo chegou e saiu da área de } \\
\text { cobertura desta Base. }\end{array}$ & 010 \\
\hline $\begin{array}{l}\text { 20. Deve ser desenvolvido um programa para o cadastro de } \\
\text { Transponders instalados, integrado ao sistema atual da } \\
\text { transportadora ou do embarcador. Estes sistemas devem } \\
\text { enviar estas informações ao Servidor Central. }\end{array}$ & $\begin{array}{l}011, \\
012\end{array}$ \\
\hline $\begin{array}{l}\text { 21. As Bases e Transponders devem ser identificadas nos } \\
\text { sistemas por um número de identificação único. Todas as } \\
\text { informações sobre eles devem conter este número. }\end{array}$ & 011 \\
\hline $\begin{array}{l}\text { 22. No sistema de monitoramento e dos usuários, as funções } \\
\text { de acompanhamento, relatórios e consultas devem ser } \\
\text { associadas aos veículos e as viagens. O usuário não } \\
\text { precisará utilizar a identificação do Transponder em suas } \\
\text { operações diárias. }\end{array}$ & 012 \\
\hline $\begin{array}{l}\text { 23. } \text { sistema da empresa (transportadora ou embarcador) } \\
\text { deve permitir o cadastro diário da rota de cada veículo, } \\
\text { assim como os horários previstos de chegada em cada } \\
\text { ponto. }\end{array}$ & 012 \\
\hline $\begin{array}{l}\text { 24. O Sistema de Transponder deve enviar aos demais } \\
\text { sistemas a data e a hora exatas da passagem de um } \\
\text { veículo por uma Base. }\end{array}$ & 012 \\
\hline
\end{tabular}




\begin{tabular}{|c|c|}
\hline Requisitos & NPV \\
\hline $\begin{array}{l}\text { 25. Se o veículo permanecer por um tempo nesta Base, o } \\
\text { Sistema de Transponders deve informar também o tempo } \\
\text { de permanência no local. }\end{array}$ & 012 \\
\hline $\begin{array}{l}\text { 26. Os sistemas de monitoramento e de usuários devem } \\
\text { fornecer a possibilidade de consultar o andamento de uma } \\
\text { viagem em um relatório (em que Bases o veículo já passou } \\
\text { e quais ainda faltam). }\end{array}$ & 012 \\
\hline $\begin{array}{l}\text { 27. Os sistemas de monitoramento e de usuários devem } \\
\text { fornecer a possibilidade de extrair relatórios de passagens } \\
\text { em Bases, selecionados por: período de tempo, por } \\
\text { Transponder ou por viagem. }\end{array}$ & 012 \\
\hline $\begin{array}{l}\text { 28. O sistema do usuário deve emitir um alerta sempre que } \\
\text { receber uma passagem de um veículo por uma Base que } \\
\text { esteja fora da rota prevista, ou foram do tempo estimado. }\end{array}$ & 012 \\
\hline $\begin{array}{l}\text { 29. Após uma instalação, deve existir um procedimento } \\
\text { simples para que o eletricista possa verificar se o } \\
\text { Transponder está operando corretamente. }\end{array}$ & 014 \\
\hline
\end{tabular}

Quadro 16 - Requisitos funcionais 


\subsubsection{Requisitos de Apresentação, Usabilidade e Fatores Humanos.}

A aparência e a facilidade de utilização são fatores importantes para o sucesso de um produto. Sendo assim, tanto os equipamentos quanto os programas do Servidor Central deverão levar em conta definições e conceitos de usabilidade e fatores humanos.

\begin{tabular}{|l|c|}
\hline \multicolumn{1}{|c|}{ Requisitos } & NPV \\
\hline 1. As embalagens para transporte do Transponder e da Base & 004 \\
devem ser projetadas para comportar o manual de & \\
instalação e o de operação, além dos respectivos & \\
acessórios. & \\
\hline 2. O preço final do Sistema de Transponders deve ser muito & 006 \\
inferior ao de um sistema de rastreamento. & 006 \\
\hline 3. O Transponder deve ser um equipamento de pequeno \\
porte. Suas dimensões não devem exceder 12 centímetros \\
de comprimento por 6 centímetros de largura e 2 \\
centímetros de altura, pois deverá ser instalado no painel \\
do veículo.
\end{tabular}




\begin{tabular}{|c|c|}
\hline Requisitos & NPV \\
\hline $\begin{array}{l}\text { 7. É desejável que o sistema de monitoramento exiba as } \\
\text { Bases por onde um veículo passou e as que ainda deve } \\
\text { passar. A visualização será mais clara se estas } \\
\text { informações forem exibidas em um mapa (graficamente). }\end{array}$ & 010 \\
\hline $\begin{array}{l}\text { 8. O cadastro de um Transponder deve conter todos os dados } \\
\text { do veículo no qual ele foi instalado. }\end{array}$ & 011 \\
\hline $\begin{array}{l}\text { 9. Os clientes e usuários devem adquirir uma ferramenta } \\
\text { gráfica para a criação de programas de cadastro e } \\
\text { visualização das rotas dos veículos em mapas. }\end{array}$ & 011 \\
\hline 10. A interface do sistema do usuário deve ser simples e clara. & 012 \\
\hline $\begin{array}{l}\text { 11. Os sistemas de monitoramento e de usuários devem exibir } \\
\text { em um mapa o andamento de uma viagem (em que Bases } \\
\text { o veículo já passou e quais ainda faltam). }\end{array}$ & 012 \\
\hline $\begin{array}{l}\text { 12. O motorista não deve ter que executar nenhuma operação } \\
\text { no Transponder. Caso detecte algum comportamento } \\
\text { inadequado do equipamento (através das luzes e sons), } \\
\text { deve informar ao suporte técnico da empresa responsável, } \\
\text { que tomará as providências necessárias. }\end{array}$ & 012 \\
\hline 13. O Transponder não pode atrapalhar o motorista. & 013 \\
\hline $\begin{array}{l}\text { 14. A instalação do Transponder não pode causar nenhum tipo } \\
\text { de dano ao veículo. }\end{array}$ & 013 \\
\hline $\begin{array}{l}\text { 15. Transponder deve possuir indicações sonoras ou } \\
\text { luminosas, para indicação de status de operação. Estas } \\
\text { indicações não podem incomodar o motorista, } \\
\text { principalmente à noite. }\end{array}$ & 013 \\
\hline $\begin{array}{l}\text { 16. O manual de instalação deve conter todos os passos de } \\
\text { instalação detalhados e com fotos ilustrativas. }\end{array}$ & 014 \\
\hline
\end{tabular}




\begin{tabular}{|c|c|}
\hline Requisitos & NPV \\
\hline $\begin{array}{l}\text { 17. O Transponder deve vir de fábrica com fitas adesivas e } \\
\text { demais acessórios para fixação no veículo. }\end{array}$ & 014 \\
\hline
\end{tabular}

Quadro 17 - Requisitos de apresentação, usabilidade e fatores humanos

\subsubsection{Requisitos de Desempenho}

\begin{tabular}{|c|c|}
\hline Requisitos & NPV \\
\hline $\begin{array}{l}\text { 1. Os clientes e usuários devem ter acesso rápido e fácil ao } \\
\text { cadastro das Bases e Transponders no sistema. }\end{array}$ & 003 \\
\hline $\begin{array}{l}\text { 2. O consumo de energia de uma Base deve ser igual ou } \\
\text { inferior ao de uma lâmpada de } 5 \mathrm{~W} \text {. }\end{array}$ & 004 \\
\hline $\begin{array}{l}\text { 3. O consumo de energia de um Transponder deve ser } \\
\text { mínimo, pois será alimentado pela bateria do veículo. }\end{array}$ & $\begin{array}{l}006 \\
013\end{array}$ \\
\hline $\begin{array}{l}\text { 4. Os usuários devem ter acesso às informações do Servidor } \\
\text { Central através da internet, } 24 \text { horas por dia. }\end{array}$ & 006 \\
\hline $\begin{array}{l}\text { 5. As Bases deverão permanecer operacionais } 24 \text { horas por } \\
\text { dia, } 7 \text { dias por semana, captando informações de todos os } \\
\text { Transponders que passarem por sua área de cobertura. }\end{array}$ & $\begin{array}{l}006 \\
008\end{array}$ \\
\hline $\begin{array}{l}\text { 6. O Servidor Central deve ser dimensionado para receber } \\
\text { dados de até } 500 \text { Bases simultaneamente. Nesta situação, } \\
\text { o tempo de resposta não pode aumentar muito. }\end{array}$ & 006 \\
\hline $\begin{array}{l}\text { 7. A base de dados do Servidor Central deve ser } \\
\text { dimensionada para armazenar os dados recebidos e } \\
\text { enviados nos últimos } 2 \text { anos. }\end{array}$ & 006 \\
\hline $\begin{array}{l}\text { 8. O Servidor Central deve estar disponível } 24 \text { horas por dia, } \\
7 \text { dias por semana. }\end{array}$ & 009 \\
\hline
\end{tabular}




\begin{tabular}{|c|c|}
\hline Requisitos & NPV \\
\hline $\begin{array}{l}\text { 9. O Transponder deve ser capaz de trocar informações com } \\
\text { uma Base, mesmo que existam outros Transponders } \\
\text { operando na mesma área (um não pode atrapalhar o } \\
\text { outro). }\end{array}$ & 010 \\
\hline $\begin{array}{l}\text { 10. As Bases instaladas em pátios de transportadoras e } \\
\text { grandes embarcadores devem suportar a troca de } \\
\text { informações com centenas de veículos, simultaneamente } \\
\text { (um pátio pode ter até } 300 \text { veículos estacionados). }\end{array}$ & 010 \\
\hline $\begin{array}{l}\text { 11. Uma Base deve ter a capacidade de armazenar } \\
\text { informações recebidas dos Transponders durante vários } \\
\text { dias, prevendo-se o caso de problemas na comunicação } \\
\text { com o Servidor Central. }\end{array}$ & 010 \\
\hline
\end{tabular}

Quadro 18 - Requisitos de desempenho

\subsubsection{Requisitos Operacionais e de Ambiente}

\begin{tabular}{|l|c|}
\hline \multicolumn{1}{|c|}{ Requisitos } & NPV \\
\hline $\begin{array}{l}\text { 1. O Servidor Central deverá ter estrutura duplicada de } \\
\text { hardware. }\end{array}$ & 003 \\
\hline $\begin{array}{l}\text { 2. Os Transponders devem ser alimentados pela bateria do } \\
\text { veículo onde forem instalados. Portanto devem operar com } \\
\text { voltagens de 12V ou 24V. }\end{array}$ & 004 \\
\hline 3. As Bases devem operar, automaticamente, tanto na & 004, \\
voltagem 110V quanto na voltagem 220V (não deve haver & 005 \\
necessidade de chaveamento manual). & \\
\hline
\end{tabular}




\begin{tabular}{|c|c|}
\hline Requisitos & NPV \\
\hline $\begin{array}{l}\text { 4. O Transponder deve ser instalado em veículos que não } \\
\text { tenham sistema de rastreamento, e que necessitem do } \\
\text { produto para o monitoramento logístico de suas viagens. }\end{array}$ & 006 \\
\hline $\begin{array}{l}\text { 5. Para redução de custo, o hardware dos equipamentos } \\
\text { deve ser projetado para operar com o mínimo de memória } \\
\text { para gravação de dados. }\end{array}$ & 006 \\
\hline $\begin{array}{l}\text { 6. O homologador do sistema deve ter acesso a todas as } \\
\text { funções disponíveis no Servidor Central. }\end{array}$ & 007 \\
\hline $\begin{array}{l}\text { 7. Os clientes e usuários devem ter acesso ao cadastro de } \\
\text { todas as Bases instaladas. }\end{array}$ & 008 \\
\hline $\begin{array}{l}\text { 8. A área de cobertura da rede de Bases instaladas deve } \\
\text { abranger todas as principais rotas de transporte de carga. }\end{array}$ & $\begin{array}{l}008 \\
010\end{array}$ \\
\hline $\begin{array}{l}\text { 9. As Bases deverão informar a passagem de um veículo ao } \\
\text { Servidor Central no menor tempo possível (ideal: }<15 \\
\text { minutos). }\end{array}$ & 008 \\
\hline $\begin{array}{l}\text { 10. Algumas estradas não fazem parte das principais rotas de } \\
\text { transporte de carga, porém são freqüentemente utilizadas } \\
\text { como "rota de fuga", em caso de roubo do veículo. Sendo } \\
\text { assim, devem ser previstas instalações de Bases em } \\
\text { alguns pontos destas estradas. }\end{array}$ & 008 \\
\hline $\begin{array}{l}\text { 11. Além das estradas, deverão ser instaladas Bases nos } \\
\text { pátios das transportadoras e grandes embarcadores. }\end{array}$ & 010 \\
\hline $\begin{array}{l}\text { 12. O sistema de monitoramento deve conhecer as Bases que } \\
\text { um veículo deve passar em uma viagem, assim como o } \\
\text { tempo gasto estimado entre elas. Em caso de atraso, ou } \\
\text { passagem por uma base fora da rota, deve ser emitido um } \\
\text { alerta ao operador deste sistema. }\end{array}$ & 010 \\
\hline
\end{tabular}


continuação

\begin{tabular}{|l|c|}
\hline \multicolumn{1}{|c|}{ Requisitos } & NPV \\
\hline 13. Caso o Transponder esteja instalado dentro do painel do & 013 \\
veículo (não visível), deve de tempos em tempos emitir um & \\
som específico, informando ao motorista que está \\
operando sem problemas.
\end{tabular}

Quadro 19 - Requisitos operacionais e de ambiente

\subsubsection{Requisitos de Manutenção e Suporte}

\begin{tabular}{|l|c|}
\hline \multicolumn{1}{|c|}{ Requisitos } & NPV \\
\hline 1. O departamento de Suporte Técnico da empresa que & 003 \\
desenvolverá o sistema deve ter um aumento da equipe \\
para atendimento 24 horas, 7 dias por semana.
\end{tabular}




\begin{tabular}{|c|c|}
\hline Requisitos & NPV \\
\hline $\begin{array}{l}\text { 7. Deve ser definido um local apropriado para testes das } \\
\text { Bases e dos Transponders fabricados. }\end{array}$ & 004 \\
\hline $\begin{array}{l}\text { 8. O departamento de produção deve receber dos } \\
\text { departamentos de Suporte Técnico e de Manutenção } \\
\text { relatórios de problemas e dificuldades com o sistema, que } \\
\text { sejam relacionadas ao hardware dos equipamentos. }\end{array}$ & 004 \\
\hline $\begin{array}{l}\text { 9. Os procedimentos de fabricação e manutenção dos } \\
\text { equipamentos devem seguir as normas ISO 9000, para } \\
\text { obtenção da certificação correspondente. }\end{array}$ & 004 \\
\hline $\begin{array}{l}\text { 10. Quando uma Base ou um Transponder for enviado para } \\
\text { manutenção, deverá ser acompanhado de um relatório } \\
\text { sobre o ocorrido. }\end{array}$ & 005 \\
\hline $\begin{array}{l}\text { 11. O departamento de Suporte e Manutenção deve contar } \\
\text { com um laboratório com ferramentas necessárias para a } \\
\text { avaliação e reparo dos equipamentos recebidos para } \\
\text { manutenção. }\end{array}$ & 005 \\
\hline $\begin{array}{l}\text { 12. Para a troca de componentes defeituosos, deve existir um } \\
\text { estoque de reposição completo no departamento de } \\
\text { Manutenção. }\end{array}$ & 005 \\
\hline $\begin{array}{l}\text { 13. Devem existir documentações claras e completas sobre os } \\
\text { procedimentos de teste e homologação dos equipamentos } \\
\text { recebidos para manutenção. }\end{array}$ & 005 \\
\hline $\begin{array}{l}\text { 14. O hardware da Base e do Transponder deve ser resistente } \\
\text { e robusto, evitando gastos com manutenção para o } \\
\text { usuário. }\end{array}$ & 006 \\
\hline
\end{tabular}

Quadro 20 - Requisitos de manutenção e suporte 


\subsubsection{Requisitos de Segurança}

\begin{tabular}{|c|c|}
\hline Requisitos & NPV \\
\hline $\begin{array}{l}\text { 1. O acesso aos relatórios e cadastros do sistema deve ser } \\
\text { controlado. Apenas usuários devidamente autorizados } \\
\text { podem ter acesso às informações. }\end{array}$ & 002 \\
\hline $\begin{array}{l}\text { 2. Devem ser definidas categorias de acesso aos usuários do } \\
\text { sistema. Algumas operações somente poderão ser } \\
\text { realizadas pelo usuário "administrador do sistema". }\end{array}$ & 002 \\
\hline $\begin{array}{l}\text { 3. Em caso de perda de alimentação (queda de energia), a } \\
\text { Base não poderá perder os dados armazenados e ainda } \\
\text { não transmitidos para o Servidor Central. }\end{array}$ & 008 \\
\hline $\begin{array}{l}\text { 4. Em caso de perda de alimentação, o Transponder não } \\
\text { poderá perder os dados armazenados e nem suas } \\
\text { configurações. }\end{array}$ & 008 \\
\hline $\begin{array}{l}\text { 5. As Bases devem ser instaladas em locais seguros para que } \\
\text { não tenham risco de roubo ou depredações. }\end{array}$ & 008 \\
\hline $\begin{array}{l}\text { 6. Os Transponders devem ser instalados na parte interna } \\
\text { dos veículos para evitar roubo ou depredações. }\end{array}$ & 008 \\
\hline
\end{tabular}

Quadro 21 - Requisitos de segurança

\subsubsection{Requisitos Culturais e Políticos}

Não foram levantados requisitos nesta categoria. 


\subsubsection{Requisitos Legais}

\begin{tabular}{|c|c|}
\hline Requisitos & NPV \\
\hline $\begin{array}{l}\text { 1. Todo software e hardware desenvolvido para a } \\
\text { comunicação entre os equipamentos devem obedecer às } \\
\text { normas da Anatel para equipamentos de radiação restrita. }\end{array}$ & 007 \\
\hline $\begin{array}{l}\text { 2. Se alguma parte do sistema necessitar de software de } \\
\text { terceiros, devem ser adquiridas junto ao fornecedor deste } \\
\text { software, tantas cópias quantas forem necessárias. }\end{array}$ & 007 \\
\hline
\end{tabular}

Quadro 22 - Requisitos legais 


\section{VALIDAÇÃO E ESPECIFICAÇÃO DOS REQUISTOS}

O documento de definição dos requisitos apresentado no capítulo anterior, foi elaborado com uma linguagem natural, seguindo a forma como as diversas pessoas participantes do processo utilizaram.

Utilizando, mais uma vez, a técnica de reuniões com os representantes dos pontos de vista identificados para o sistema, iniciou-se a etapa de validação final dos requisitos.

Durante duas reuniões, que contaram com a participação de alguns clientes, usuários e desenvolvedores, cada um dos requisitos foi analisado e validado por todos os participantes, mostrando que a atividade de análise e negociação dos requisitos foi bem feita.

A partir do documento de definição dos requisitos fechado e validado, a próxima e última etapa do processo, foi a elaboração do documento de especificação de requisitos para o sistema proposto.

O Apêndice A apresenta o documento de especificação de requisitos para o Sistema de Transponders, construído a partir do modelo sugerido no documento IEEE Std 830-1998 (IEEE, 1998, p. 11), com algumas adaptações para aproveitar a estrutura já utilizada do Volere. 


\section{CONSIDERAÇÕES FINAIS}

A participação do setor de transportes de cargas na economia brasileira é significativamente alta, representando $4,4 \%$ do PIB nacional. A atividade de transporte rodoviário de carga representa mais de 60\% das operações de transporte realizadas no Brasil, envolvendo mais de 60 mil empresas.

Assim como em outros setores, o investimento na melhoria dos produtos e serviços prestados pelas empresas do setor de TRC tem sido cada vez maior. A maioria destas empresas tem focado na adoção de produtos e sistemas que controlem desde o estoque dos armazéns até as logísticas de coleta e distribuição das mercadorias. Embora a oferta de produtos e sistemas seja grande, a crescente concorrência tem obrigado as empresas deste setor a otimizarem cada vez mais seus custos, dificultando a aquisição destes produtos.

Somente empresas cuja carga transportada seja de alto valor agregado conseguem cobrar mais pelo frete, justificando o investimento em ferramentas e sistemas eficientes e modernos, mais que possuem um custo elevado. Esta realidade é verificada em uma minoria das empresas do setor de TRC.

Através de uma pesquisa das opções existentes no mercado brasileiro, verificou-se que existe uma carência de produtos de baixo custo, que forneçam informações úteis para o controle de operações relacionadas ao transporte de mercadorias de baixo valor agregado. Diante desta constatação iniciou-se um estudo sobre o desenvolvimento de um novo produto.

Ao considerar-se o fato de que problemas com requisitos são responsáveis pelo insucesso de um grande número de produtos e sistemas, optou-se pela elaboração de uma Especificação de Requisitos para um sistema que preenchesse a lacuna existente no mercado. Para isso, este trabalho baseou-se nas teorias e definições da Engenharia de Requisitos.

Dentre as diversas técnicas e métodos para o levantamento e especificação de requisitos, o método Volere mostrou-se mais abrangente e flexível, norteando a estruturação das atividades a serem executadas. Esta flexibilidade permitiu que os conceitos de outros dois métodos, o Vord e Preview, fossem incorporados a sua estrutura. 
A composição dos métodos Volere, Vord e Preview facilitou a identificação das diversas partes interessadas no sistema, e a coleta e organização das informações. Durante as reuniões realizadas com os representantes destas partes, observou-se a satisfação dos mesmos com relação ao formulário de preenchimento dos requisitos do Sistema de Transponders, e a forma como as atividades de análise e validação destes requisitos foram conduzidas.

A colaboração e disciplina de todas as partes envolvidas foram primordiais para que este trabalho alcançasse seus objetivos.

Considerando as premissas de que o processo de levantamento e definição dos requisitos para o novo produto não poderia ser demorado e trabalhoso, o resultado final obtido foi muito satisfatório. A aplicação dos métodos descritos no processo de levantamento, análise e validação dos requisitos foi considerada prática e satisfatória por toda equipe envolvida, atingindo o objetivo maior desta proposta: a definição de um processo eficiente de levantamento de requisitos. A Especificação de Requisitos para o Sistema de Transponders, representa uma base sólida para 0 desenvolvimento deste sistema.

Vale a pena ressaltar que o sucesso do Sistema de Transponders não depende apenas da Especificação de Requisitos. Cabe aos profissionais envolvidos na especificação e desenvolvimento do sistema o cumprimento destes requisitos, assim como o seu gerenciamento.

\subsection{Contribuições}

A principal contribuição desse trabalho reside na análise das necessidades tecnológicas das empresas do setor de TRC e na proposição de um sistema que atenda estas necessidades.

A decisão de elaborar para este sistema uma Especificação de Requisitos que não despendesse muito tempo de projeto implicou no estudo e avaliação de diversos métodos e tecnologias existentes na literatura.

Como resultante deste estudo, elaborou-se uma estrutura para o processo de definição dos requisitos do sistema, baseada em alguns dos métodos existentes. 
Essa estrutura mostra-se bastante interessante como um mecanismo de levantamento e definição dos requisitos de um sistema.

\subsection{Trabalhos futuros}

Considerando o modelo apresentado nesta proposta para o processo de levantamento e definição de requisitos, pretende-se automatizar algumas atividades deste processo, através do desenvolvimento de um programa de software que colete e processe as informações atualmente preenchidas no formulário de requisitos adaptado do método Volere (Figura 11).

Outra linha de trabalho deverá utilizar esta estrutura de processo para a definição de requisitos para outros produtos e sistemas. 


\section{REFERÊNCIAS}

ASSOCIAÇÃO BRASILEIRA DE NORMAS TÉCNICAS. NBR 14857-2: Sistemas espaciais gerenciamento do programa - parte 2: garantia do produto. Rio de Janeiro, 2002. 7p.

ALEXANDER, I. F. A taxonomy of stakeholders: human roles in system development. In: INTERNATIONAL JOURNAL OF TECHNOLOGY AND HUMAN INTERACTION, v. 1, n. 1, p. 23-59, 2005.

ALEXANDER, P.; RAMIN T. K. Requirements engineering in the development of innovative automotive embedded software systems. In: IEEE INTERNATIONAL REQUIREMENTS ENGINEERING CONFERENCE, 12., 2004, Kyoto. Proceedings...Kyoto: 2004. p. 328-333.

AVIZIENIS, A. The four-universe information system model for the study of fault-tolerance. In: IEEE INTERNATIONAL SYMPOSIUM ON FAULT TOLERANT COMPUTING, 12., 1982, Santa Mônica. Proceedings... Santa Mônica: 1982. p.29-33.

BLAHA M; RUMBAUGH J. Object-oriented modeling and design with UML. $2^{\text {nd }}$ ed., Prentice Hall, 2004. 496 p.

BOEHM, B. W. Software engineering economics. Prentice Hall, 1981. 767p.

Verifying and validating software requirements and design specification. IEEE Software, v. 1, n. 1, p. 75-88, Jan. 1984.

A spiral model of software development and enhancement, IEEE Computer, v. 21, n. 5, p. 61-72, May 1988.

BOWERSOX, D. J.; CLOSS, D. J. Logistical management: the integrated supply chain process. Singapore: McGraw-Hill, 1996, 752p.

CARVALHO, M. M.; GUSTIN, G. B.; NERY, R. Uso do QFD no setor de serviços: avaliação de uma transportadora rodoviária de carga. In: ENCONTRO NACIONAL DE ENGENHARIA DE PRODUÇÃO, 21., 2001, Salvador. Anais.... Porto Alegre: ABEPRO, 2001. p. 1-8.

CASTRO, J. F. B. Introdução à engenharia de requisitos. In. XX CONGRESSO DA SOCIEDADE BRASILEIRA DE COMPUTAÇÃO, 20., Canela, 1995. v. 1, p. 1-43.

CHRISTOPHER, M. Logística e gerenciamento da cadeia de suprimentos. 1. ed., São Paulo: Pioneira, 1997. $240 \mathrm{p}$.

CNT, Confederação Nacional do Transporte. Disponível em: < http://www.cnt.org.br>. Acesso em: 10 out. 2006.

DAVIS, A. M. Software requirements: objects, functions and states. $2^{\text {nd }}$ ed., Upper Saddle River, NJ: Prentice Hall, 1993. 521p.

DAVIS, A. M.; HICKEY, A. M. (2002). Viewpoints: requirements researchers: do we practice what we preach?. REQUIREMENTS ENGINEERING JOURNAL, v. 7, n. 2, p. 107-111, London: Springer London, 2000. 
DICSEG. Dicionário de Seguros. Disponível em: <http://www.cvgrj.com.br>. Acesso em: 25 jul. 2006.

DORFMAN, M; THAYER, R. H. Standards, guidelines, and examples on system and software requirements engineering. p. 324-363, Los Alamitos: IEEE Computer Society Press Tutorial, 1990.

ENGE, P.; MISHRA P. Special issue on global positioning system. PROCEEDINGS OF THE IEEE, v. 87, n. 1, p. 3-15, Jan. 1999.

ESPITI. European User Survey Analysis. Report USV_EUR 2.1 Espiti Project, European Software Institute, July 1996. 25 p.

GAJSKI, D. D.; VAHID F.; NARAYAN S.; GONG J. Specification and Design of Embedded Systems. $1^{\text {st }}$ ed., Prentice Hall, 1994. 450 p.

GOGUEN, J. A.; JIROTKA, M. Requirements engineering: social and technical issues. p. 165-199, Academic Press, 1994.

GRADY, B; RUMBAUGH, J.; JACOBSON, I. The unified modeling language user guide. Addison-Wesley, 1998. 482p.

HOFMANN, B.; LICHTENEGGER H.; COLLINS, J. Global positioning system: theory and practice. $4^{\text {th }}$ ed., Springer-Verlag, 1997.

HOFMANN, H. F.; LEHNER, F. Requirements engineering as a success factor in software projects, p. 58-66, IEEE Software, Jul. 2001.

IEEE, IEEE Std 610.12 - IEEE Standard glossary of software engineering terminology. New York: IEEE Computer Society, 1990. 84 p.

, IEEE Std 1233 - IEEE Guide for developing system requirements specifications. New York: IEEE Computer Society, 1998a. 30 p.

, IEEE Std 830 - IEEE Recommended practice for software requirements specifications. New York: IEEE Computer Society, 1998b. 31 p.

JACKSON, M. Software requirements and specifications: a lexicon of practice, principles and prejudices. Addison-Wesley, 1995. 256p.

JACOBSON, I. Object-oriented software engineering: a use case driven approach, AddisonWesley, 1992. $552 \mathrm{p}$.

JANSCH P. I.; WEBER, T. S. Recuperação de processos em sistemas distribuídos. REVISTA DE INFORMÁTICA TEÓRICA E APLICADA, v. 4, n. 1, p.107-138, jul. 1997.

KOTONYA, G.; SOMMERVILLE, I. Requirements engineering with viewpoints. SOFTWARE ENGINEERING JOURNAL, v.11, n. 1, p. 5-18, Jan. 1996.

Requirements engineering: processes and techniques. Wiley, 1998. 294p.

LAMSWEERDE, A. V. Requirements engineering in the year 00: a research perspective. INTERNATIONAL CONFERENCE ON SOFTWARE ENGINEERING, 22., june 2000, Limerick. Proceedings... Limerick: 2000. p. 5-19. 
LEE, W. J.; CHA, S. D.; KWON, Y. R. Integration and analysis of use cases using modular petri nets in requirements engineering. In: IEEE TRANSACTIONS ON SOFTWARE ENGINEERING, v. 24, n. 12, p. 1115-1130, Dec. 1998.

LEFFINGWELL, D.; WIDRIG, D. Managing software requirements: a unified approach. Addison-Wesley, 1999. 528p.

LEITE, J. C. S. P.; HADAD, G. D. S.; DOORN, J. H.; KAPLAN, G. N. A scenario construction process. REQUIREMENTS ENGINEERING JOURNAL, v. 5, n. 1, p. 38-61, London: Springer-Verlag, 2000.

Scenario inspections. REQUIREMENTS ENGINEERING JOURNAL, v. 10, n. 1, p. 1-21, London: Springer London, 2005.

MACAULAY, L. A. Requirements engineering. New York: Springer-Verlag, 1996. 202 p.

MACOHIN, G. A. De transportador a operador logístico - a lacuna a ser preenchida: um estudo de caso. 2001. 156 p. Dissertação (Mestrado) - Universidade Federal de Santa Catarina. Florianópolis, 2001.

NUSEIBEH, B.; EASTERBROOK, S. Requirements engineering: a roadmap. INTERNATIONAL CONFERENCE ON SOFTWARE ENGINEERING, 22., June 2000, Limerick. Proceedings... Limerick: 2000. p. 35-46.

PFLEEGER, S. L. Engenharia de software: teoria e prática. 2. ed., São Paulo: Prentice Hall, 2004. 560p.

PINHEIRO, F. A. C. Viewpoints: requirements honesty. REQUIREMENTS ENGINEERING JOURNAL, v. 8, n. 3, p. 183-192, London: Springer London, 2003.

PORTER, M. E. Estratégia competitiva: técnicas para análise de indústrias e da concorrência. 5. ed., p. 22-48, Rio de Janeiro: Campus, 1991.

PRADHAN, D. K. Fault-tolerant system design. p. 1-8, New Jersey: Prentice Hall, 1996.

RAMADURAI, V. Localization in wireless sensor networks with inaccurate range measurements. 2003. 96 p. Dissertação (Mestrado) - Graduate Faculty of North Carolina State University. Raleigh, 2003.

ROBERTSON, S.; ROBERTSON J. Mastering the requirements process, Addison-Wesley, 1999. 352 p.

SCHULTZ, T. W. C and the 8051: building efficient applications. v. 2. Prentice Hall, 1999. $457 \mathrm{p}$.

SOMMERVILLE, I; SAWYER, P. Viewpoints: principles, problems and a practical approach to requirements engineering. ANNALS OF SOFTWARE ENGINEERING. v. 3, p. 101-130, Jan. 1997a.

Requirements engineering: a good practice guide, Wiley, 1997b. 404p.

SOMMERVILLE, I. Software engineering. $7^{\text {th }}$ ed., Addison-Wesley, 2004. 784p.

TECH D. The online computer dictionary. Disponível em: <http://techdictionary.com>. Acesso em: 15 abr. 2007. 
WOLF, W. Computers as components: principles of embedded computing system design. San Francisco: Morgan Kaufmann Publishers, 2001. 688 p.

ZAVE, P. Classification of research efforts in requirements engineering. ACM COMPUTING SURVEYS, v. 29, n. 4, p. 315-321. New York: ACM Press, Oct. 1997. 


\section{Apêndice A - ESPECIFICAÇÃO DE REQUISITOS PARA O SISTEMA DE TRANSPONDERS}

\section{A.1 Introdução}

No mercado brasileiro de transporte rodoviário de cargas, o monitoramento das viagens executadas pelos veículos tem se tornado cada vez mais importante. Atualmente, os produtos e sistemas disponíveis para este tipo de operação, têm um custo muito elevado para a grande maioria das empresas.

Diante desta lacuna do mercado, o desenvolvimento de um sistema que monitore e forneça dados sobre as viagens executadas por uma frota, a um baixo custo de implantação e manutenção, parece ser perfeitamente viável. Este desenvolvimento, no entanto, deve partir de uma especificação de requisitos bem elaborada.

\section{A.1.1 Objetivos}

Este documento tem o objetivo de definir os requisitos para um sistema de monitoramento de veículos no transporte rodoviário de cargas, obtidos a partir de um processo de levantamento e análise junto à desenvolvedores, clientes e usuários.

Esta especificação visa descrever sistematicamente as propriedades funcionais necessárias ao novo sistema, e deverá ser utilizada pelos analistas, projetas e engenheiros como base para o desenvolvimento deste sistema.

\section{A.1.2 Escopo do Sistema}

Sistemas sofisticados para gerenciamento de frotas que possibilitam desde a localização geográfica exata de um veículo, até o acionamento remoto de travas e dispositivos de segurança, são comercializados no Brasil. Atualmente, a maioria destes sistemas tem um custo muito elevado, o que inviabiliza sua utilização por grande parte da frota brasileira.

O sistema a ser desenvolvido, denominado Sistema de Transponders, visa atender estas empresas, que buscam por uma tecnologia que forneça informações básicas 
para o acompanhamento logístico de seus veículos, aliado ao baixo custo de implantação e manutenção.

\section{A.1.3 Nomenclaturas e Definições}

O Sistema de Transponders será composto por um conjunto de equipamentos de hardware e softwares, cujo projeto e desenvolvimento partirá desta especificação.

A estrutura geral deste sistema será formada por: equipamentos instalados nos veículos, equipamentos instalados em pontos fixos ao logo das principais rodovias do país e um servidor central. Cada uma destas partes receberá os seguintes nomes:

Transponder - equipamento instalado nos veículos.

Base - equipamento instalado em pontos fixos das rodovias.

Servidor Central - servidor (computador) central do sistema.

Os seguintes nomes serão utilizados nesta proposta:

Leds - abreviação para "Light Emmiting Diodes", que significa "Diodos Emissores de Luz". São indicadores luminosos, colocados nos painéis de alguns equipamentos, e que podem ser de diversas cores (vermelho, verde, amarelo, etc.).

Logs - informações gravadas em memória pelos equipamentos durante sua execução, cuja análise permite diagnosticar todas as operações realizadas.

\section{A.1.4 Organização do Documento}

O próximo item fornece uma descrição geral do sistema, relacionando os fatores que, de alguma forma, afetam o Sistema de Transponders e seus requisitos. Em seguida, o item A.3 detalha os requisitos funcionais e não funcionais que deverão ser considerados no projeto e desenvolvimento do sistema. 


\section{A.2 Descrição Geral}

As opções tecnológicas disponíveis atualmente no mercado brasileiro para o monitoramento de viagens no transporte rodoviário de carga vão desde sistemas de rastreamento caros e sofisticados, a controles simples que dependam de telefonemas dos motoristas reportando suas operações.

O Sistema de Transponders deverá preencher a lacuna existente neste mercado, fornecendo informações básicas a um preço reduzido. Para isso, o projeto de hardware e software de cada uma das partes deste sistema deve prever a utilização de componentes e meios de comunicação de custo reduzido.

\section{A.2.1 Perspectiva do Produto}

Um dos principais objetivos deste produto é possibilitar aos clientes e usuários, o recebimento de dados confiáveis e precisos sobre as viagens executadas pelos veículos de sua frota. Para isso, devem ser projetados dois tipos de equipamento de hardware:

- Transponders: para instalação em caminhões de grande porte (utilizados pela grande maioria das empresas para o transporte de cargas);

- Bases: para instalação em pontos fixos ao longo de rodovias.

Além disso, o sistema deve contar com o Servidor Central que receberá, processará e transmitirá as informações aos clientes e usuários do sistema.

A operação interligada das diversas partes do Sistema de Transponders possibilitará aos clientes e usuários, o recebimento de dados confiáveis e precisos sobre as viagens executadas por um ou mais veículos de sua frota. 


\section{A.2.1.1 Interfaces}

Conforme já mencionado anteriormente, o Sistema de Transponders será composto por Transponders, Bases e um Servidor Central. Embora a operação de cada uma destas partes deva ser autônoma, a perfeita integração entre elas é fundamental para o sucesso do produto. A comunicação entre elas deve ser feita através de uma conexão, cujo meio utilizado deve ser:

- radiofreqüência ou GPRS, para comunicação entre o Transponder e a Base);

- linha telefônica discada ou GPRS, para comunicação entre a Base e o Servidor Central.

A Figura 12 contém a arquitetura geral do sistema, mostrando a interface de cada uma destas partes:

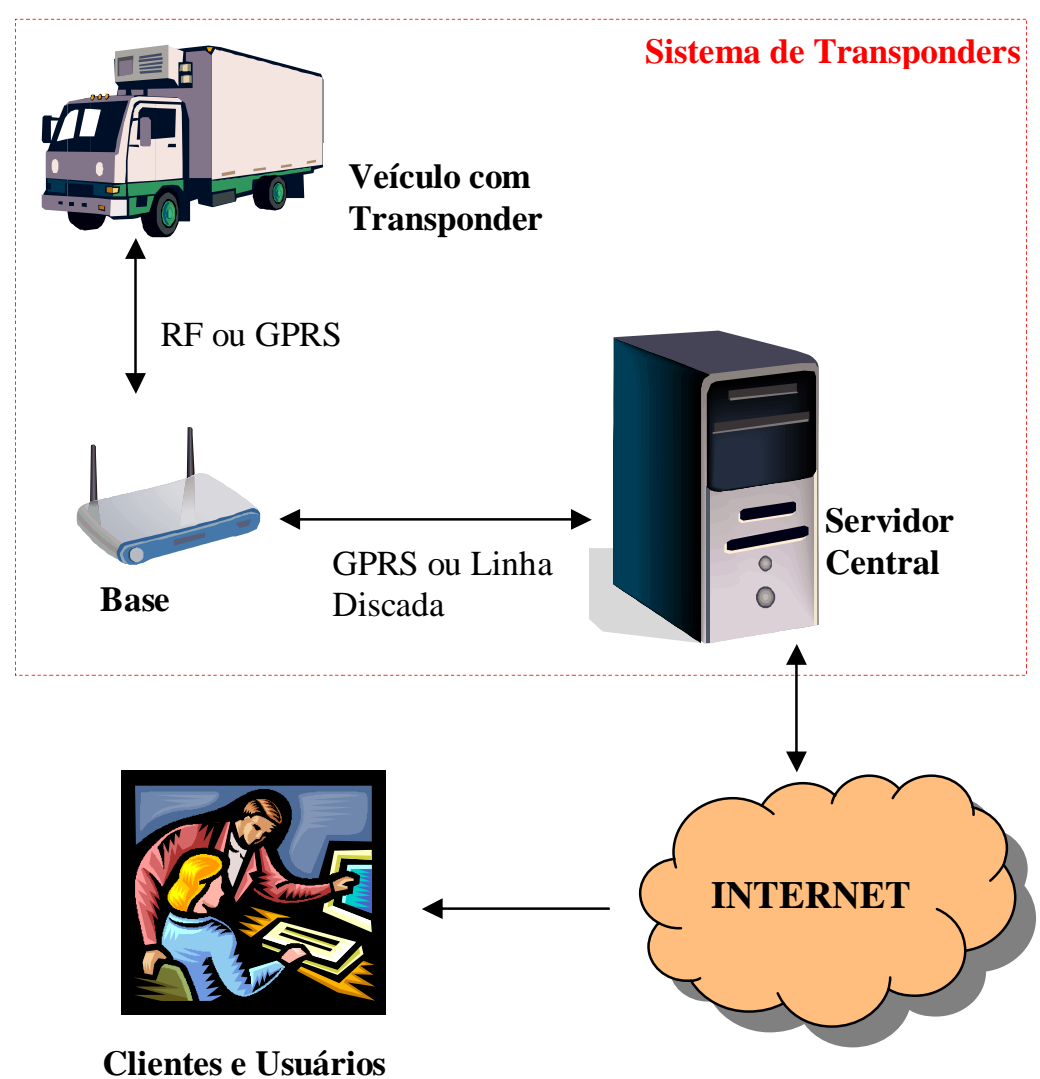

Figura 12 - Interfaces do sistema (especificação de requisitos) 


\section{A.2.2 Funções do Produto}

O Sistema de Transponders é composto por três grandes partes: Transponders, Bases e um Servidor Central.

Este item descreve as principais funções que devem ser executadas por cada uma destas partes.

\section{A.2.3 Funções do Transponder}

O Transponder deve ser um equipamento de pequeno porte, a ser instalado e utilizado em veículos de transporte de cargas. Depois de instalado, deverá executar as seguintes funções:

1. O Transponder deve possuir no seu painel frontal, três leds indicativos: "desativado", "motor ligado" e "conexão";

2. O Transponder poderá estar configurado em um dos seguintes estados: operacional ou desativado. Sempre que estiver no estado desativado, o led "desativado" deve permanecer aceso;

3. Monitorar o estado do motor do veículo, armazenando o tempo em que este estiver ligado e desligado;

4. Se o motor do veículo estiver ligado, o led "motor ligado" deve permanecer aceso;

5. Ao detectar a presença de uma Base, o Transponder deve conectar-se a ela, informando sua identificação e os dados armazenados sobre o motor do veículo;

6. Se o Transponder estiver conectado a uma Base, o led "conexão" deve permanecer aceso; 


\section{A.2.4 Funções da Base}

A Base deve ser um equipamento de pequeno porte, a ser instalado e utilizado em pontos fixos ao longo das principais rodovias, ou em depósitos de carga. Depois de instalada, deverá executar as seguintes funções:

1. A Base deve possuir no seu painel frontal, os seguintes leds indicativos: "ligado", "conexão transponder", "conexão central", "estado 1" e "estado 2". Estes leds devem ser acesos e apagados, de acordo com as operações realizadas;

2. A operação deve iniciar assim que a Base for ligada à energia elétrica, sem a necessidade de intervenção humana. Quando estiver, o led "ligado" deve permanecer aceso;

3. Ao detectar a conexão de um Transponder, deve informar para ele sua identificação, receber e armazenar os dados recebidos deste Transponder;

4. Durante a conexão de um Transponder à Base, o led "conexão transponder" deve permanecer aceso;

5. De tempos em tempos, a Base deve conectar-se ao Servidor Central para: transmitir todos os dados de Transponders armazenados, transmitir informações sobre se estado operacional e, receber atualizações de software e configurações;

6. Durante uma conexão com o Servidor Central, o led "conexão central" deve permanecer aceso;

7. Situações de erro detectadas pelo software devem ser registradas e transmitidas posteriormente para o Servidor Central. Além disso, os leds "estado 1" e "estado 2" devem acender ou piscar de acordo com uma tabela de erros a ser definida.

\section{A.2.5 Funções do Servidor Central}

O Servidor Central deve ser um microcomputador com grande capacidade de memória e processamento, com sistema operacional Linux instalado. O hardware 
deste equipamento deve ser comprado pronto, sendo seu desenvolvimento restrito ao software aplicativo. Depois de instalado, o software deste servidor deverá executar as seguintes funções:

1. Os dados recebidos das Bases devem ser armazenados em um banco de dados;

2. Ao receber a conexão de uma Base, deve verificar se existe alguma atualização pendente, aproveitando esta conexão para enviar esta atualização;

3. Possibilitar o cadastramento de Bases e Transponders através da internet. $O$ acesso aos cadastros e outras informações deve ser controlado por nível de usuário;

4. Fornecer informações sobre as Bases e os Transponders através de relatórios disponibilizados via internet, ou através de solicitações recebidas dos sistemas de clientes, também através da internet;

5. Controlar as conexões e mensagens recebidas das Bases, gerando relatórios para o suporte técnico, caso detecte algum problema;

6. Todas as funções executadas e disponibilizadas pelo Servidor Central devem estar disponíveis 24 horas por dia, 7 dias por semana.

\section{A.2.6 Características do Usuário}

Os clientes e usuários deste sistema deverão ser as empresas de logística e de gerenciamento de riscos, que necessitam monitorar viagens de diversas empresas, e possuem toda a estrutura para o gerenciamento das informações. Além disso, estas empresas definem o valor do seguro a ser pago em cada viagem de transporte de carga, e podem associar descontos neste valor para veículos que possuam o Sistema de Transponders (isto já é feito para veículos que possuem sistemas de rastreamento).

Motoristas autônomos que prestam serviços de transporte de carga para estas empresas, também são usuários potenciais deste sistema, pois poderão adquirir e 
instalar Transponders em seus veículos, possibilitando o monitoramento de suas viagens por parte das empresas que os contratarem.

Os motoristas dos veículos têm em geral um nível de escolaridade baixo, e sua familiaridade com equipamentos com algum grau de tecnologia é quase inexistente. Sendo assim, os Transponders devem operar sem a necessidade de intervenção por parte do motorista.

As Bases também deverão operar de forma autônoma, pois ficarão instaladas em pontos fixos de rodovias, onde não existirão pessoas disponíveis e habilitadas para sua operação.

\section{A.2.7 Restrições}

Um fator importante na definição dos requisitos de um sistema, é a definição prévia das restrições e premissas deste sistema. Diferentemente da grande maioria dos requisitos, estas devem, obrigatoriamente, ser atendidas pelo produto.

Os itens abaixo descrevem as principais premissas ou restrições que o Sistema de Transponders deve obedecer, juntamente com a razão e os critérios que devem ser seguidos em cada caso:

a) Deverá haver um equipamento de pequeno porte, a ser instalado nos veículos que serão monitorados pelo sistema.

Razão: Para que os veículos possam ser monitorados, eles precisam ter algum tipo de equipamento que troque informações com as demais partes do sistema.

Critério: O equipamento deverá ser facilmente instalado no painel do veículo a ser monitorado. Suas dimensões não poderão exceder 12 centímetros de comprimento por 6 centímetros de largura e 2 centímetros de altura.

b) O equipamento a ser instalado no veículo deverá ser de fácil instalação.

Razão: Não deverão existir oficinas de instalação do produto. Os usuários finais deverão ser capazes de instalar o equipamento somente com o auxílio de um manual. 
Critério: Os fios para a instalação do equipamento deverão ser conectados à caixa de fusíveis do veículo, cujo acesso é fácil em todos os tipos de veículo.

c) A tecnologia utilizada para a troca de informações entre o equipamento instalado no veículo e as demais partes do sistema deverá ser economicamente viável.

Razão: O alto custo da comunicação de dados pode inviabilizar um sistema.

Critério: De acordo com o tipo de comunicação definido, deverão existir equipamentos fixos, instalados ao longo das principais rodovias brasileiras, capazes de receber executar esta troca de informações com os veículos.

d) Se algum dos equipamentos do sistema utilizar comunicação por Radiofreqüência (RF) ou por Telefonia Celular, estes deverão ser homologados e certificados pela Anatel (Agência Nacional de Telecomunicações).

Razão: Para a comercialização de equipamentos que utilizem comunicação por RF ou Telefonia Celular, é necessário que estes possuam uma etiqueta adesiva de certificação da Anatel. A Anatel é uma empresa governamental que define regras de utilização e de comportamento para equipamentos de telecomunicações no Brasil.

Critério: Os projetos de hardware e de software dos equipamentos que utilizarem RF ou Telefonia Celular, deverão seguir as regras e procedimentos regulamentados e padronizados pela Anatel. Os primeiros protótipos deverão ser enviados para homologação e certificação na Anatel.

e) Deverá existir um servidor central (computador) instalado no CPD da empresa que desenvolverá o sistema, e conectado à rede internet 24 horas por dia. Este servidor receberá as informações dos pontos instalados ao logo das rodovias, e deverá disponibilizá-las também via internet aos clientes e usuários do sistema.

Razão: A operação de monitoramento deve ser feita 24 horas por dia, e a troca de informações através da internet é mais barata. 
Critério: O servidor central deverá ter grande capacidade de memória e processamento.

f) O hardware dos equipamentos instalados nos veículos e nas rodovias deverá ter pouca memória para gravação de programas e dados.

Razão: Os componentes de memória devem ser reduzidos para diminuição do custo de produção do equipamento.

Critério: Deverá ser previsto o mínimo de memória possível para a gravação dos programas e dos dados necessários.

g) O software dos equipamentos a serem instalados nos veículos e nas rodovias deverá ser desenvolvido na linguagem $\mathrm{C}$.

Razão: A empresa que desenvolverá o sistema já possui ferramentas e profissionais especializados, além desta linguagem ser indicada para equipamentos a serem embarcados.

Critério: Deverá ser utilizada a linguagem C para o desenvolvimento deste software.

h) O software do servidor central deverá ser desenvolvido na linguagem Java.

Razão: A empresa que desenvolverá o sistema já possui ferramentas e profissionais especializados, além desta linguagem ser indicada para sistemas que utilizam a internet.

Critério: Deverá ser utilizada a linguagem Java para o desenvolvimento deste software.

\section{A.3 Requisitos}

Levando-se em conta os objetivos, restrições e premissas já definidos, este item descreve os requisitos para o desenvolvimento do Sistema de Transponders. O processo de levantamento, análise e validação dos requisitos para este sistema foi norteado pelos métodos Volere, Vord e Preview. Uma das principais técnicas utilizadas neste processo foi a de pontos de vista (viewpoints), que baseia-se no fato 
de que os requisitos de um sistema devem ser obtidos através de várias perspectivas deste sistema, ou seja, de diferentes pontos de vista.

As diversas partes interessadas no sistema foram separadas por classe de ponto de vista, aos quais os requisitos foram associados. A cada um dos pontos de vista atribuiu-se um número, conforme apresentado nas Tabelas 7, 8 e 9.

Para efeito de rastreabilidade, os requisitos definidos nos próximos itens apresentam os números de identificação de cada ponto de vista que os originou.

Tabela 7 - Identificação dos pontos de vista da classe Desenvolvedor

\begin{tabular}{cc}
\hline & \multicolumn{2}{c}{ Classe Desenvolvedor } \\
\hline Número & Ponto de Vista \\
\hline 001 & Gerente do Projeto \\
\hline 002 & Analista de Sistemas \\
\hline 003 & Gerente de Suporte Técnico \\
\hline 004 & Engenheiro de Produção \\
\hline 005 & Engenheiro de Manutenção \\
\hline 006 & Gerente Comercial \\
\hline 007 & Homologador \\
\hline
\end{tabular}


Tabela 8 - Identificação dos pontos de vista da classe Cliente

\begin{tabular}{cc}
\hline & \multicolumn{2}{c}{ Classe Cliente } \\
\hline Número & Ponto de Vista \\
\hline 008 & Analista de Riscos \\
\hline 009 & Analista de Sistemas \\
\hline 010 & Gerente de Logística \\
\hline
\end{tabular}

Tabela 9 - Identificação dos pontos de vista da classe Usuário Final

\begin{tabular}{cc} 
Número & $\begin{array}{c}\text { Classe Usuário Final } \\
\text { Ponto de Vista }\end{array}$ \\
\hline 011 & Analista de Sistemas \\
\hline 012 & Gerente de Logística \\
\hline 013 & Motorista do Veículo \\
\hline 014 & Eletricista Automotivo \\
\hline
\end{tabular}

Embora o modelo sugerido pela norma IEEE Std 830-1998 apresente algumas opções de formatação para a especificação de requisitos, este documento define os requisitos, agrupando-os segundo a divisão abaixo.

- Requisitos de Desenvolvimento;

- Requisitos Funcionais;

- Requisitos de Apresentação, Usabilidade e Fatores Humanos;

- Requisitos de Desempenho;

- Requisitos Operacionais e de Ambiente; 
- Requisitos de Manutenção e Suporte;

- Requisitos de Segurança;

- Requisitos Legais.

\section{A.3.1 Requisitos de Desenvolvimento}

Os requisitos de desenvolvimento se aplicam as condutas e procedimentos que devem ser seguidos pela equipe que especificará e desenvolverá o Sistema de Transponders.

Os requisitos a seguir devem ser considerados do início ao fim do desenvolvimento:

1. Todos os recursos alocados para este projeto precisam estar disponíveis durante todo o tempo estipulado (NPV 001);

2. Devem ser definidos mecanismos que facilitem a comunicação entre o gerente do projeto, a equipe de desenvolvimento e os usuários (NPV 001);

3. O software desenvolvido tem que ser de ótima qualidade (NPV 001);

4. Todas as decisões tomadas nas reuniões de projeto devem ser registradas em ata (NPV 001);

5. O desenvolvimento do software deve ser iniciado somente após a conclusão e a aprovação das especificações de implementação dos programas (NPV 001);

6. A especificação de requisitos do sistema deve atender ao maior número possível de stakeholders (NPV 001);

7. As especificações de implementação dos programas devem ser iniciadas somente após a conclusão e a aprovação das especificações funcional e de interfaces do sistema (NPV 001);

8. O desenvolvimento do software deve seguir os padrões de codificação e nomenclaturas definidos pela empresa que os desenvolverá (NPV 001);

9. Deve ser definido um padrão para todas as especificações e documentações do projeto (NPV 001); 
10. Especificação de requisitos deve estar consistente e sem ambigüidades (NPVs 002 e 007);

11. Devem ser disponibilizadas para a equipe de desenvolvimento, ferramentas para codificação, depuração e gravação dos programas nos respectivos equipamentos (NPV 002);

12. Devem ser desenvolvidos programas de teste para simulação dos Transponders, Bases e Servidor Central (NPV 002);

13. O banco de dados a ser utilizado no Servidor Central deve ser o SQL Server (NPV 002);

14. Deve ser disponibilizado para a equipe de desenvolvimento um ou mais equipamentos para análise de protocolos (NPV 002);

15. Devem ser fabricados protótipos dos equipamentos Transponder e Base (NPV 002);

16. Deve ser definido um modelo a ser adotado nas especificações e codificação dos programas (NPV 002);

17. O software desenvolvido para o Transponder e para a Base deve ser desenvolvido na linguagem de programação "C" (NPV 002);

18. O software desenvolvido para o Servidor Central deve ser feito na linguagem de programação JAVA (NPV 002);

19. O software desenvolvido para o Transponder e para a Base deve ser tolerante a falhas, ou seja, deve executar procedimentos de recuperação de erros, voltando ao estado operacional, sem que haja intervenção humana (NPV 002);

20. A escolha definitiva dos componentes do Transponder e da Base deve ser feita após a conclusão dos testes com os protótipos (NPV 004);

21. Devem ser desenvolvidos programas de teste para utilização na linha de produção das Bases e dos Transponders (NPV 004);

22. Deve ser elaborado um documento de especificação da interface entre o Sistema de Transponders e os demais sistemas (NPV 007); 
23. Devem ser desenvolvidos programas de teste para utilização na homologação do sistema (NPV 007);

24. Devem ser disponibilizados diversos equipamentos (Transponders e Bases) para os testes de homologação (NPV 007).

\section{A.3.2 Requisitos Funcionais}

Os requisitos funcionais delimitam um conjunto mínimo de funcionalidades e esperadas de um sistema ou produto. Este conjunto é o resultado de uma análise criteriosa e amplamente discutida por todas as partes envolvidas com o produto.

As principais funcionalidades que o Sistema de Transponders deve oferecer são:

1. O Transponder deve ter leds com cores distintas, indicando seu estado de operação (NPV 003);

2. A Base deve ter leds com cores distintas, indicando seu estado de operação (NPV 003);

3. Atualização remota dos programas e configurações dos Transponders e Bases deve estar prevista no sistema (NPV 003);

4. O sistema deve fornecer funções que possibilitem a verificação remota do status de uma Base ou Transponder (NPV 003);

5. O sistema deve fornecer funções para a extração remota de logs das operações realizadas por uma Base ou Transponder (NPV 003);

6. O Servidor Central deve emitir, automaticamente, relatórios de Bases e Transponders com possíveis problemas (NPV 003);

7. O sistema de monitoramento deve informar ao Sistema de Transponders quando não receber a passagem de um veículo por uma Base, localizada entre duas outras que reportaram a passagem deste veículo (isto pode indicar que a Base está inoperante). Ao receber este aviso, o sistema deverá emitir um alerta de Base com suspeita de problemas (NPV 003); 
8. Mesmo que não existam eventos de Transponder para enviar, a Base deve enviar, de tempos em tempos, uma mensagem com seu estado operacional ao Servidor Central (NPV 003);

9. No Servidor Central devem existir relatórios para análise e aprovação dos testes dos equipamentos produzidos (NPV 004);

10. O Servidor Central deve disponibilizar aos usuários, relatórios que forneçam o maior número de informações sobre os Transponders em utilização (NPV 006);

11. Nas localidades onde for possível, a comunicação entre as Bases e o Servidor Central deve ser feita através de uma conexão GPRS (NPV 006);

12. Em caso de roubo de um veículo com Transponder, deve ser possível informar as Bases para que estas dêem prioridade ao envio da passagem deste veículo na sua área de cobertura (NPV 008);

13. O sistema de monitoramento deve emitir um alerta caso receba uma passagem de veículo por uma Base instalada em uma possível "rota de fuga", ou fora da rota prevista (NPV 008);

14. A troca de informações entre os sistemas dos clientes e usuários deve ser feita através da web (Internet) (NPVs 009 e 011);

15. O protocolo utilizado para troca de informações entre os sistemas deve ser 0 XML, e os dados devem estar criptografados (NPVs 009 e 011);

16. O Servidor Central deve informar aos demais sistemas, as alterações no cadastro de Bases e Transponders (NPVs 009 e 011);

17. O Servidor Central deve enviar avisos aos demais sistemas, quando uma Base apresentar problemas de comunicação, assim como quando ela voltar a sua operação normal (NPVs 009 e 012);

18. Ao conectar-se a uma Base, o Transponder deve informar dados sobre o motor do veículo (ligado ou desligado, tempo total ligado ou desligado, etc.) (NPVs 010 e 012); 
19. Sempre que estabelecer uma comunicação com um Transponder, a Base deve enviar um evento de "passagem" para o Servidor Central, informando todos os dados obtidos. Nestes dados devem constar também a data e o horário que o veículo chegou e saiu da área de cobertura desta Base (NPV 010);

20. Deve ser desenvolvido um programa para o cadastro de Transponders instalados, integrado ao sistema atual da transportadora ou do embarcador. Estes sistemas devem enviar estas informações ao Servidor Central (NPVs 011 e 012);

21. As Bases e Transponders devem ser identificadas nos sistemas por um número de identificação único. Todas as informações sobre eles devem conter este número (NPV 011);

22. No sistema de monitoramento e dos usuários, as funções de acompanhamento, relatórios e consultas devem ser associadas aos veículos e as viagens. O usuário não precisará utilizar a identificação do Transponder em suas operações diárias (NPV 012);

23. O sistema da empresa (transportadora ou embarcador) deve permitir o cadastro diário da rota de cada veículo, assim como os horários previstos de chegada em cada ponto (NPV 012);

24. O Sistema de Transponder deve enviar aos demais sistemas a data e a hora exatas da passagem de um veículo por uma Base (NPV 012);

25. Se o veículo permanecer por um tempo nesta Base, o Sistema de Transponders deve informar também o tempo de permanência no local (NPV 012);

26. Os sistemas de monitoramento e de usuários devem fornecer a possibilidade de consultar o andamento de uma viagem em um relatório (em que Bases o veículo já passou e quais ainda faltam) (NPV 012);

27. Os sistemas de monitoramento e de usuários devem fornecer a possibilidade de extrair relatórios de passagens em Bases, selecionados por: período de tempo, por Transponder ou por viagem (NPV 012); 
28. O sistema do usuário deve emitir um alerta sempre que receber uma passagem de um veículo por uma Base que esteja fora da rota prevista, ou foram do tempo estimado (NPV 012);

29. Após uma instalação, deve existir um procedimento simples para que o eletricista possa verificar se o Transponder está operando corretamente (NPV 014).

\section{A.3.3 Requisitos de Apresentação, Usabilidade e Fatores Humanos.}

A aparência e a facilidade de utilização são fatores importantes para o sucesso de um produto. Considerando esta afirmação, a concepção das partes do sistema que terão uma interação direta com o usuário, deve ser uma atividade cuidadosamente estudada. Desde a definição das telas de relatórios do Servidor Central até as embalagens de acondicionamento dos Transponders e Bases, deve-se levar em conta definições e conceitos de usabilidade e fatores humanos.

Os requisitos para a apresentação e utilização do Sistema de Transponders são:

1. As embalagens para transporte do Transponder e da Base devem ser projetadas para comportar o manual de instalação e o de operação, além dos respectivos acessórios (NPV 004);

2. O preço final do Sistema de Transponders deve ser muito inferior ao de um sistema de rastreamento (NPV 006);

3. O Transponder deve ser um equipamento de pequeno porte. Suas dimensões não devem exceder 12 centímetros de comprimento por 6 centímetros de largura e 2 centímetros de altura, pois deverá ser instalado no painel do veículo (NPV 006);

4. A caixa externa do Transponder deve ser confeccionada em material plástico e leve, para que não emita ruídos de trepidação no painel do veículo (NPV 006); 
5. Qualquer eletricista automotivo deve ser capaz de instalar o Transponder, apenas com o auxílio do manual de instalação. Este processo não deve consumir mais de uma hora do trabalho de um eletricista (NPVs 006 e 014);

6. O cadastro das Bases deve conter o endereço completo, nome da empresa, nome do responsável e as coordenadas geográficas (latitude e longitude) do ponto onde a Base está instalada (NPVs 008 e 010);

7. É desejável que o sistema de monitoramento exiba as Bases por onde um veículo passou e as que ainda deve passar. A visualização será mais clara se estas informações forem exibidas em um mapa (graficamente) (NPV 010);

8. O cadastro de um Transponder deve conter todos os dados do veículo no qual ele foi instalado (NPV 011);

9. Os clientes e usuários devem adquirir uma ferramenta gráfica para a criação de programas de cadastro e visualização das rotas dos veículos em mapas (NPV 011);

10. A interface do sistema do usuário deve ser simples e clara (NPV 012);

11. Os sistemas de monitoramento e de usuários devem exibir em um mapa o andamento de uma viagem (em que Bases o veículo já passou e quais ainda faltam) (NPV 012);

12. 0 motorista não deve ter que executar nenhuma operação no Transponder. Caso detecte algum comportamento inadequado do equipamento (através das luzes e sons), deve informar ao suporte técnico da empresa responsável, que tomará as providências necessárias (NPVs 012 e 013);

13.O Transponder não pode atrapalhar o motorista (NPV 013);

14. A instalação do Transponder não pode causar nenhum tipo de dano ao veículo (NPV 013);

15. O Transponder deve possuir indicações sonoras ou luminosas, para indicação de status de operação. Estas indicações não podem incomodar o motorista, principalmente à noite (NPV 013); 
16.O manual de instalação deve conter todos os passos de instalação detalhados e com fotos ilustrativas (NPV 014);

17. O Transponder deve vir de fábrica com fitas adesivas e demais acessórios para fixação no veículo (NPV 014).

\section{A.3.4 Requisitos de Desempenho}

O desempenho de um sistema pode ser definido como a maneira com que o sistema se comporta, é determinado por suas características de execução. O comportamento esperado de um sistema varia de acordo com os objetivos de cada parte envolvida.

Os requisitos de desempenho das diversas partes envolvidas com este sistema foram discutidos e ponderados, chegando-se as seguintes definições:

1. Os clientes e usuários devem ter acesso rápido e fácil ao cadastro das Bases e Transponders no sistema (NPV 003);

2. O consumo de energia de uma Base deve ser igual ou inferior ao de uma lâmpada de 5W (NPV 004);

3. O consumo de energia de um Transponder deve ser mínimo, pois será alimentado pela bateria do veículo (NPVs 006 e 013);

4. Os usuários devem ter acesso às informações do Servidor Central através da internet, 24 horas por dia (NPV 006);

5. As Bases devem permanecer operacionais 24 horas por dia, 7 dias por semana, captando informações de todos os Transponders que passarem por sua área de cobertura (NPVs 006 e 008);

6. O Servidor Central deve ser dimensionado para receber dados de até 500 Bases simultaneamente. Nesta situação, o tempo de resposta não pode aumentar muito (NPV 006); 
7. A base de dados do Servidor Central deve ser dimensionada para armazenar os dados recebidos e enviados nos últimos 2 anos (NPV 006);

8. O Servidor Central deve estar disponível 24 horas por dia, 7 dias por semana (NPV 009);

9. O Transponder deve ser capaz de trocar informações com uma Base, mesmo que existam outros Transponders operando na mesma área (um não pode atrapalhar o outro) (NPV 010);

10. As Bases instaladas em pátios de transportadoras e grandes embarcadores devem suportar a troca de informações com centenas de veículos, simultaneamente (um pátio pode ter até 300 veículos estacionados) (NPV 010);

11. Uma Base deve ter a capacidade de armazenar informações recebidas dos Transponders durante vários dias, prevendo-se o caso de problemas na comunicação com o Servidor Central (NPV 010).

\section{A.3.5 Requisitos Operacionais e de Ambiente}

No projeto de um sistema deve-se levar em consideração o ambiente no qual este sistema deverá operar. Neste caso, a palavra "ambiente" pode significar desde o tipo de máquina onde o sistema será executado, até o seu local físico. De acordo com este ambiente, muitas premissas e requisitos devem ser considerados.

O Sistema de Transponders é dividido em três grandes partes, cada uma delas tendo sua particularidade no que diz respeito à operação e ambiente. Levando-se em conta esse universo, os requisitos operacionais e de ambiente para este sistema são:

1. O Servidor Central deve ter uma estrutura duplicada de hardware (NPV 003);

2. Os Transponders devem ser alimentados pela bateria do veículo onde forem instalados. Portanto devem operar com voltagens de 12V ou 24V (NPV 004); 
3. As Bases devem operar, automaticamente, tanto na voltagem $110 \mathrm{~V}$ quanto na voltagem 220V (não deve haver necessidade de chaveamento manual) (NPVs 004 e 005);

4. O Transponder deve ser instalado em veículos que não tenham sistema de rastreamento, e que necessitem do produto para o monitoramento logístico de suas viagens (NPV 006);

5. Para redução de custo, o hardware dos equipamentos deve ser projetado para operar com o mínimo de memória para gravação de dados (NPV 006);

6. O homologador do sistema deve ter acesso a todas as funções disponíveis no Servidor Central (NPV 007);

7. Os clientes e usuários devem ter acesso ao cadastro de todas as Bases instaladas (NPV 008);

8. A área de cobertura da rede de Bases instaladas deve abranger todas as principais rotas de transporte de carga (NPVs 008 e 010);

9. As Bases devem informar a passagem de um veículo ao Servidor Central no menor tempo possível (ideal: < 15 minutos) (NPV 008);

10. Algumas estradas não fazem parte das principais rotas de transporte de carga, porém são freqüentemente utilizadas como "rota de fuga", em caso de roubo do veículo. Sendo assim, devem ser previstas instalações de Bases em alguns pontos destas estradas (NPV 008);

11. Além das estradas, deve ser prevista a instalação de Bases nos pátios das transportadoras e grandes embarcadores (NPV 010);

12. O sistema de monitoramento deve conhecer as Bases que um veículo deve passar em uma viagem, assim como o tempo gasto estimado entre elas. Em caso de atraso, ou passagem por uma base fora da rota, deve ser emitido um alerta ao operador deste sistema (NPV 010);

13. Caso o Transponder esteja instalado dentro do painel do veículo (não visível), deve, de tempos em tempos, emitir um som específico, informando ao motorista que está operando sem problemas (NPV 013). 


\section{A.3.6 Requisitos de Manutenção e Suporte}

Mesmo que um produto (ou sistema) atenda perfeitamente aos requisitos funcionais, operacionais, de apresentação e de desempenho, sempre existirão casos onde uma manutenção ou suporte técnico serão solicitados pelo usuário. Neste momento é fundamental que o fabricante deste produto ofereça um bom suporte técnico e uma manutenção rápida e eficiente.

Para isso os departamentos responsáveis por estes serviços devem ser providos de ferramentas adequadas e pessoal capacitado. Para alcançar este objetivo, o Sistema de Transponders deve obedecer aos seguintes requisitos de manutenção e suporte:

1. O departamento de Suporte Técnico da empresa que desenvolverá o sistema deve ter um aumento da equipe para fornecer atendimento aos clientes e usuários durante 24 horas, 7 dias por semana (NPV 003);

2. A instalação dos equipamentos deve ser simples para minimizar as chamadas ao suporte técnico (NPV 003);

3. Todas as versões do sistema devem ser detalhadas na especificação funcional (NPV 003);

4. Os manuais de instalação e operação dos equipamentos devem ser claros e de linguagem simples (NPV 003);

5. Uma Base deve sair de fábrica com todas as configurações necessárias para sua operação. O instalador deverá precisar apenas conectá-la à rede elétrica (tomada 110V ou 220V) (NPV 003);

6. O Servidor Central deve disponibilizar ao suporte técnico, comandos e relatórios para o envio e recepção de dados das Bases, a qualquer momento (NPV 003);

7. Deve ser definido um local apropriado para testes das Bases e dos Transponders fabricados (NPV 004); 
8. O departamento de produção deve receber dos departamentos de Suporte Técnico e de Manutenção relatórios de problemas e dificuldades com o sistema, que sejam relacionadas ao hardware dos equipamentos (NPV 004);

9. Os procedimentos de fabricação e manutenção dos equipamentos devem seguir as normas ISO 9000, para obtenção da certificação correspondente (NPV 004);

10. Quando uma Base ou um Transponder for enviado para manutenção, deve ser acompanhado de um relatório descrevendo o problema ocorrido (NPV 005);

11.O departamento de Suporte e Manutenção deve contar com um laboratório com ferramentas necessárias para a avaliação e reparo dos equipamentos recebidos para manutenção (NPV 005);

12. Para a troca de componentes defeituosos, deve existir um estoque de reposição completo no departamento de Manutenção (NPV 005);

13. Devem existir documentações claras e completas sobre os procedimentos de teste e homologação dos equipamentos recebidos para manutenção (NPV 005);

14.O hardware da Base e do Transponder deve ser resistente e robusto, evitando gastos com manutenção para o usuário (NPV 006).

\section{A.3.7 Requisitos de Segurança}

A segurança de um produto ou sistema pode ser vista sob vários aspectos: segurança contra vandalismos (depredações ou roubos), segurança contra acessos não permitidos, ou segurança quanto a perda de informações em caso de falhas.

Os requisitos de segurança definidos para o Sistema de Transponders são: 
1. $O$ acesso aos relatórios e cadastros do sistema deve ser controlado. Apenas usuários devidamente autorizados podem ter acesso às informações) (NPV 002);

2. Devem ser definidas categorias de acesso aos usuários do sistema. Algumas operações somente poderão ser realizadas pelo usuário "administrador do sistema" (NPV 002);

3. Em caso de perda de alimentação (queda de energia), a Base não pode perder os dados armazenados e ainda não transmitidos para o Servidor Central (NPV 008);

4. Em caso de perda de alimentação, o Transponder não poderá perder os dados armazenados e nem suas configurações (NPV 008);

5. As Bases devem ser instaladas em locais seguros para que não tenham risco de roubo ou depredações (NPV 008);

6. Os Transponders devem ser instalados na parte interna dos veículos para evitar roubo ou depredações (NPV 008).

\section{A.3.8 Requisitos Legais \\ A comercialização de um produto ou sistema deve respeitar algumas leis específicas.}

Considerando-se o tipo de utilização previsto para o Sistema de Transponders, seus requisitos legais são:

1. Todo software e hardware desenvolvido para a comunicação entre os equipamentos devem obedecer às normas da Anatel para equipamentos de radiação restrita (NPV 007);

2. Se alguma parte do sistema necessitar de software de terceiros, devem ser adquiridas junto ao fornecedor deste software, todas as licenças necessárias (NPV 007). 


\section{Anexo A - Método Vord}

No método Vord, um ponto de vista é uma entidade cujos requisitos são responsáveis ou impõe restrições ao desenvolvimento de um sistema. Os pontos de vista podem ser classificados em duas categorias (KOTONYA; SOMMERVILLE, 1996, p. 09):

- Pontos de vista diretos: Correspondem aos clientes recebendo serviços do sistema e enviando-Ihe dados e informações de controle. Representam operadores/usuários ou subsistemas que interagem com o sistema sendo analisado;

- Pontos de vista indiretos: Que tem interesses em alguns ou todos os serviços oferecidos pelo sistema, porém não interagem diretamente com ele. Eles geram requisitos que restringem os serviços oferecidos a pontos de vista diretos (geram requisitos não funcionais). Pontos de vista indiretos vão desde pontos de vista de engenharia (cujo foco de interesse são o projeto e a implementação do sistema), passando por pontos de vista organizacionais (que focalizam a influência do sistema na organização) até pontos de vista externos (com preocupações relacionadas às influências do sistema em seu ambiente externo).

O método Vord discute as seguintes etapas:

- Identificação e estruturação dos pontos de vista relevantes ao sistema;

- Documentação dos pontos de vista;

- Análise e especificação dos requisitos dos pontos de vista. 


\section{A.1 Identificação dos Pontos de Vista}

A identificação dos pontos de vista deve partir das necessidades da organização e das classes abstratas de pontos de vista. Para isso, devem ser identificados:

- Os pontos de vista irrelevantes ao sistema com base nos pontos de vista abstratos pré-definidos. Estes devem ser eliminados.

- Stakeholders, certificando-se de que todos estejam sempre representados em algum ponto de vista.

- Outros pontos de vistas relevantes com base nos modelos de uma arquitetura de sistema (provavelmente já existentes na maioria dos casos).

- Operadores do sistema que o utilizam constantemente, ocasionalmente ou que mandam os outros fazerem as coisas para eles. Estes são potenciais pontos de vista.

- Papéis de pessoas que estejam associadas a classes de pontos de vista indiretos. Geralmente têm-se pontos de vista associados com cada papel.

Uma vez determinados os pontos de vistas relevantes, tem-se de documentá-los adequadamente.

\section{A.2 Documentação dos Pontos de Vista}

Para cada ponto de vista associa-se um conjunto de requisitos (funcionais, não funcionais e de controle), fontes e restrições. Os requisitos de controle descrevem a seqüência de eventos envolvidos na troca de informações entre um ponto de vista direto e o sistema. As restrições descrevem como os requisitos são afetados por requisitos não funcionais definidos por outros pontos de vista.

Um aspecto relevante do método são os cenários de eventos. Eles representam as seqüências de eventos e as exceções que podem surgir durante a troca de 
informações e o sistema. Os eventos podem ser a respeito do ponto de vista (refletindo a percepção que o usuário possui da aplicação dos requisitos de controle), ou serem eventos de sistema, refletindo os requisitos de controle. Esta distinção permite:

- Rastrear requisitos de controle a partir da perspectiva do usuário;

- Rastrear controles de sistema para pontos de vista;

- Expor conflitos entre requisitos de controle;

- Capturar a natureza distribuída e em camadas dos controles. 


\section{Anexo B - Método Preview}

O método Preview - Process and Requirements Engineering Viewpoints, é uma evolução do Vord. Ele é voltado a elicitação de requisitos, que podem ser expressos em qualquer notação (linguagem natural ou formal). A análise, diferentemente do Vord, _é dirigida pelos objetivos organizacionais (chamados de concerns).

Um ponto de vista no Preview tem um escopo limitado. Descreve explicitamente sua perspectiva, e é composto por:

- Nome: Identifica o ponto de vista, geralmente refletindo seu foco;

- Foco: Perspectiva adotada pelo ponto de vista;

- Objetivo: Preocupação. Reflete o objetivo organizacional, comercial e limites que dirigem o processo de análise;

- Fontes: Pessoas, documentos, objetos de onde são extraídas as informações do ponto de vista;

- Requisitos: Os requisitos do ponto de vista;

- Histórico: Mudanças efetuadas no ponto de vista.

Como dito anteriormente, a análise é dirigida pelos objetivos organizacionais. Eles refletem os objetivos estratégicos do sistema (por exemplo: segurança, manutenibilidade e disponibilidade), e podem ser divididos em sub-objetivos e assim por diante. A cada um deles são associadas perguntas, sendo estas utilizadas para dirigir o processo de descoberta de requisitos e servindo como um checklist durante a análise dos mesmos.

O foco é a característica que determina o ponto de vista. Cada ponto de vista tem um foco único, podendo, eventualmente, sobrepor os focos de outros pontos de vista, caracterizando assim fontes de possíveis conflitos. De certa forma, o foco mapeia itens do domínio da aplicação e do sistema. Algumas vantagens podem ser destacadas da utilização de focos: 
- Provê uma base para análise de cobertura;

- Ajuda a identificar pontos de vista com requisitos conflitantes;

- Permite descobrir fontes de requisitos;

- Os focos que se restringem ao domínio da aplicação ajudam a identificar pontos de vista que encapsulam requisitos reutilizáveis.

Resumidamente, as etapas definidas no método Preview são:

1) Levantamento dos requisitos:

a) Identificação dos objetivos organizacionais: Determinar que propriedades fundamentais o sistema deve exibir se ele deve ser bem sucedido;

b) Elaboração dos objetivos organizacionais, detalhando-os e especificando seus requisitos não funcionais;

c) Identificação dos pontos de vista;

d) Descoberta dos requisitos de cada ponto de vista.

2) Análise dos requisitos: Identificar requisitos inconsistentes com os objetivos e com requisitos, descobrindo assim conflitos internos e externos dos pontos de vista. Os conflitos internos são identificados através dos objetivos organizacionais, enquanto que os conflitos externos através do foco.

3) Negociação de requisitos. 


\section{Anexo C - Método Volere}

O método de especificação de requisitos Volere define uma seqüência de seções (capítulos) para a obtenção e especificação dos requisitos de um produto, e é baseado em casos de uso. Este produto pode ser uma parte de um software, uma parte de um hardware, um produto para o consumidor final, um conjunto de rotinas ou qualquer coisa que seja foco de um projeto. Este método atua como uma lista de verificação de requisitos que precisam ser observados e detalhados (ROBERTSON, S.; ROBERTSON J., 1999, p. 278).

\section{C.1 Estrutura do Método}

A estrutura do Volere é dividida em 27 seções, cada uma com atividades que devem ser seguidas passo a passo. Neste trabalho abordaremos somente as 17 primeiras seções, ao final das quais os requisitos do produto já estarão identificados e validados, podendo-se finalizar a especificação dos requisitos.

O título destas seções é:

1. Objetivos do Projeto

2. Clientes, consumidores e outros Stakeholders

3. Usuários do Produto

4. Restrições do Produto

5. Nomenclaturas e Definições

6. Fatos Relevantes e Suposições

7. Escopo do Negócio

8. Escopo do Produto

9. Requisitos Funcionais e de Dados

10. Requisitos de Apresentação

11. Requisitos de Usabilidade e Fatores Humanos 
12. Requisitos de Performance

13. Requisitos Operacionais e de Ambiente

14. Requisitos de Manutenção e Suporte

15. Requisitos de Segurança

16. Requisitos Culturais e Políticos

17. Requisitos Legais

O detalhamento das 8 primeiras seções estabelece a viabilidade do projeto. Todas as informações levantadas nestas seções serão de suma importância para as demais etapas e, portanto, devem ser revisadas, para que não existam dúvidas ou ambigüidades.

\section{C.2 Identificação dos Eventos e Casos de Uso}

Com base nas informações já registradas, deve-se identificar os eventos e casos de uso associados ao negócio e ao produto em questão. Isto facilitará a posterior definição dos requisitos do sistema.

O contexto da seção 7 define o escopo que deve ser estudado, através da construção de um diagrama de contexto do negócio. Este diagrama identifica o trabalho que deve ser investigado para a definição do novo produto.

Cada entrada e saída definidas neste diagrama pode representar um evento de negócio. Cada um destes eventos deve ser registrado em uma lista da seguinte forma: nome do evento, a entrada e as saídas associadas, e um resumo do caso de uso de negócio que responderá a este evento. Isto formará a Lista de Eventos de Negócio. 


\section{C.2.1 Casos de Uso do Negócio}

Segundo a definição do método Volere, na maioria das vezes, ao analisar-se a Lista de Eventos de Negócio, haverá um ou mais eventos relacionados à principal razão para o desenvolvimento do projeto, e que podem ser chamados de "eventos chave".

Os casos de uso do negócio devem ser elaborados a partir dos eventos chave.

Nesta etapa, é fundamental o auxílio do maior número possível de stakeholders, para que se tenha a certeza de que todas as pessoas relevantes deram sua contribuição para a definição da interface (técnica ou de negócio).

\section{C.3 Casos de Uso do Produto}

As definições registradas até a seção 7: objetivo, restrições, escopo, stakeholders, aliadas aos casos de uso do negócio, proporcionam conhecimento suficiente para que se possa agora decidir sobre a interface do produto. Para isso, deve-se elaborar os casos de uso do produto. Um diagrama de caso de uso identifica os limites entre os usuários (atores) e o produto. Através da análise de cada caso de uso do negócio, em conjunto com os respectivos stakeholders, pode-se definir quais partes deste caso de uso devem ser automatizadas pelo produto e quais devem ser feitas pelo usuário. Isto definirá as interfaces do produto.

Uma vez identificadas as interfaces do produto, na seção 8 parte-se para a construção dos casos de uso do produto. Estes diagramas devem mostrar os usuários (atores) fora dos limites (interfaces) do produto.

\section{C.4 Levantamento e Definição dos Requisitos}

Através dos casos de uso do produto podem ser obtidos os requisitos funcionais e não funcionais. Depois de identificar o maior número de requisitos nos casos de uso do produto, deve-se levantar outros requisitos relacionados à seção 4 e as seções de 9 a 17. 
Para padronizar o registro de todos os requisitos levantados nesta etapa, o método Volere sugere a utilização do cartão padrão. A Figura 13 mostra uma adaptação deste cartão, utilizada neste trabalho.

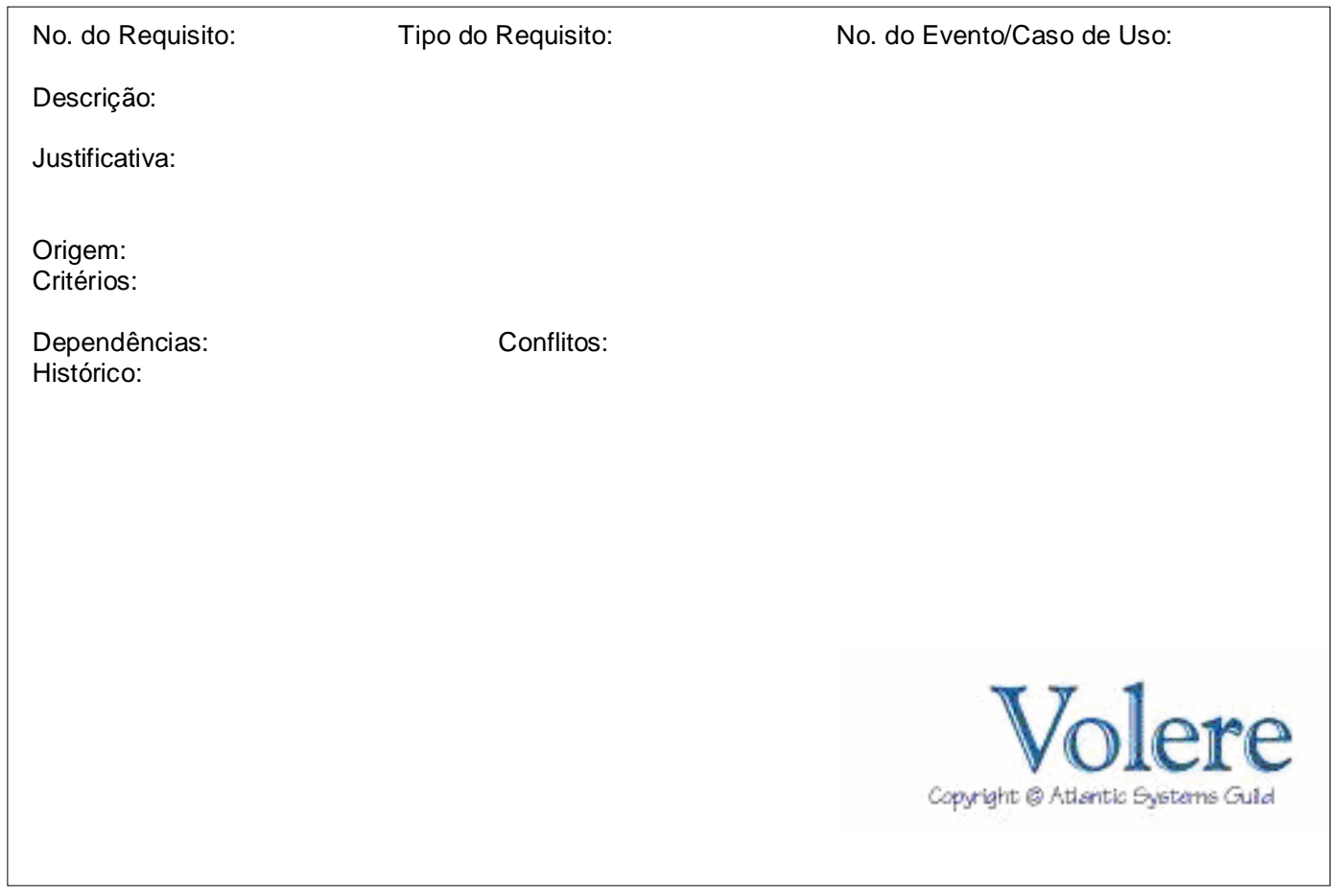

Figura 13 - Cartão padrão de requisitos adaptado do método Volere

É importante que, para cada requisito, seja identificado e registrado neste cartão os seguintes atributos: número de identificação único, descrição, justificativa e critérios que ele deverá obedecer. Estes atributos tornam possível a análise e o teste dos requisitos.

\section{C.5 Teste dos Requisitos}

Ao final da seção 17, todos os requisitos já foram definidos e agora precisam ser ou não aprovados. O propósito desta etapa é testar cada um dos requisitos antes de incorporá-lo na especificação de requisitos final.

Para ser aprovado, um requisito deve ser: 
- Completo

- Correto

- Compreensível

- Rastreável

- Consistente

- Conciso

- Relevante

- Claro e não Ambíguo

- Ambigüidade

- Viável

Após as modificações e validações decorrentes dos testes dos requisitos, o documento de especificação de requisitos do produto pode ser finalizado. 